UNIVERSIDADE DE SÃO PAULO

FFCLRP - DEPARTAMENTO DE BIOLOGIA

PROGRAMA DE PÓS-GRADUAÇÃO EM BIOLOGIA COMPARADA

\title{
Avaliação do ciclo do carbono em ecossistemas de pastagens tropicais em cenário futuro de mudanças climáticas
}

Vitor Potenza Bossan

Dissertação apresentada à Faculdade de Filosofia, Ciências e Letras de Ribeirão Preto da USP, como parte das exigências para obtenção do título de Mestre em Ciências, Área: Biologia Comparada

RIBEIRÃO PRETO - SP 
Avaliação do ciclo do carbono em ecossistemas de pastagens tropicais em cenário futuro de mudanças climáticas

\author{
Versão Corrigida
}

Dissertação apresentada à Faculdade de Filosofia, Ciências e Letras de Ribeirão Preto da USP, para obtenção do título de Mestre em Ciências.

Área de concentração: Biologia Comparada

Orientador: Prof. Dr. Carlos Alberto Martinez y Huaman

Ribeirão Preto 
Autorizo a reprodução e divulgação total ou parcial deste trabalho, por qualquer meio convencional ou eletrônico, para fins de estudo e pesquisa, desde que citada a fonte.

Catalogação da Publicação

Serviço de Documentação

Faculdade de Filosofia, Ciências e Letras de Ribeirão Preto

Universidade de São Paulo

Bossan, Vitor Potenza

Avaliação do ciclo do carbono em ecossistemas de pastagens tropicais em cenário futuro de mudanças climáticas, Ribeirão Preto, 2017. 85p.: il.; $30 \mathrm{~cm}$

Dissertação de Mestrado, apresentada à Faculdade de Filosofia, Ciências e Letras de Ribeirão Preto/USP. Área de concentração: Biologia Comparada.

Orientador: Martinez y Huaman, Carlos Alberto.

1. Aquecimento. 2. Elevado $\mathrm{CO}_{2}$. 3. Restrição hídrica. 4. Forrageira tropical. 5. Produtividade. 
Nome: BOSSAN, Vitor Potenza

Título: Avaliação do ciclo do carbono em ecossistemas de pastagens tropicais em cenário futuro de mudanças climáticas

Dissertação apresentada à Faculdade de Filosofia, Ciências e Letras de Ribeirão Preto da USP, para obtenção do título de Mestre em Ciências, Área: Biologia Comparada

Aprovado em:

Banca Examinadora

Prof.(a) Dr.(a): Instituição:

Julgamento: Assinatura:

Prof.(a) Dr.(a): Instituição:

Julgamento: Assinatura:

Prof.(a) Dr.(a): Instituição:

Julgamento: Assinatura:

Prof.(a) Dr.(a): Instituição:

Julgamento: Assinatura: 


\section{Agradecimento}

Agradeço à Universidade de São Paulo, à Faculdade de Filosofia, Ciências e Letras de Ribeirão Preto, ao Programa de Pós-graduação em Biologia Comparada e à Coordenação para o Aperfeiçoamento do Pessoal de Ensino Superior (CAPES) pelo apoio estrutural e financeiro.

Agradeço a todos do Laboratório de Fisiologia Vegetal e colegas que compartilham o bloco da Botânica.

Agradeço a meu orientador Prof. Dr. Carlos Alberto Martinez y Huaman e co-orientador Eduardo Augusto Dias de Oliveira por toda ajuda e oportunidade.

Agradeço à banca examinadora por ter aceitado o convite e pelas sugestões.

Agradeço aos meus pais Valmir e Carolina, à minha namorada Giselle e aos familiares que, sempre com muito amor e carinho, me apoiaram em minhas decisões e me deram suporte para essa conquista.

Obrigado a todos! 
Vocês que fazem parte dessa massa

Que passa nos projetos do futuro

É duro tanto ter que caminhar

E dar muito mais do que receber

E ter que demonstrar sua coragem

À margem do que possa parecer

E ver que toda essa engrenagem

Já sente a ferrugem lhe comer

Lá fora faz um tempo confortável

A vigilância cuida do normal

Os automóveis ouvem a notícia

Os homens a publicam no jornal

E correm através da madrugada

A única velhice que chegou

Demoram-se na beira da estrada

E passam a contar o que sobrou!

O povo foge da ignorância Apesar de viver tão perto dela E sonham com melhores tempos idos Contemplam essa vida numa cela

Alceu Valença e Zé Ramalho, Vida de Gado. 


\section{RESUMO}

BOSSAN, V.P. Avaliação do ciclo do carbono em ecossistemas de pastagens tropicais em cenário futuro de mudanças climáticas. 2017. 85f. Dissertação (Mestrado) - Faculdade de Filosofia, Ciências e Letras de Ribeirão Preto, Universidade de São Paulo, Ribeirão Preto, 2017.

O aquecimento global e as alterações nos padrões de precipitação são algumas das mudanças observadas no clima do planeta nos últimos anos. Simultaneamente, observa-se o aumento da concentração de gás carbônico ( $\left.\left[\mathrm{CO}_{2}\right]\right)$ na atmosfera, devido principalmente a ações antrópicas. A elevação da $\left[\mathrm{CO}_{2}\right]$ e da temperatura atmosférica global podem intensificar o efeito estufa, alterar a dinâmica de trocas gasosas das plantas e o ciclo do carbono nos ecossistemas. Isso ocorre tanto por influencias na fotossíntese, quanto nas respirações auto e heterotrófica. Outros fatores, como a umidade do solo também podem interferir nestes processos. As pastagens são ecossistemas de relevante importância para o ser humano e impactantes na dinâmica global do ciclo do carbono. A agricultura é a mais ampla forma de uso antrópico do solo e estoca mais de $10 \%$ de todo carbono da biosfera. Com o intuito de investigar o impacto das mudanças climáticas na dinâmica do $\mathrm{CO}_{2}$ e no ciclo do carbono nos ecossistemas de pastagem, este trabalho teve como objetivo quantificar a produção de biomassa, o fluxo líquido de $\mathrm{CO}_{2}$ do ecossistema (NEE), a respiração do solo e o fluxo de metano em ecossistemas de pastagem tropical. Duas espécies forrageiras, Panicum maximum Jacq. Cv Mombaça (gramínea $\mathrm{C}_{4}$ ), e Stylosanthes capitata Vogel (Leguminosa $\mathrm{C}_{3}$ ), foram cultivadas sob elevada concentração de $\mathrm{CO}_{2}\left(600 \mu \mathrm{mol} \mathrm{mol}{ }^{-1}\right)$, elevada temperatura atmosférica $\left(+2{ }^{\circ} \mathrm{C}\right)$ e restrição hídrica em sistema combinado FACE (Free-air carbon dioxide enrichment) e T-FACE (Temperature free-air controlled enhancement). A quantificação do NEE foi realizada por câmaras de topo aberto desenvolvidas pelo grupo de pesquisa especificamente para o estudo ecofisiológico integrado de todo o dossel e não apenas de uma fração da área foliar ou pela biomassa, que são atualmente as técnicas mais utilizadas. No experimento utilizando a leguminosa $C_{3}$ foi observado diminuição na biomassa total acima do solo, pela diminuição da quantidade de folhas, em tratamento com elevada temperatura (eT) e um aumento na biomassa de caules em tratamento combinado de elevada $\left[\mathrm{CO}_{2}\right]$ e temperatura $(\mathrm{eC}+\mathrm{eT})$. O NEE diurno aumentou sob tratamento de elevada $\left[\mathrm{CO}_{2}\right](\mathrm{eC})$. A respiração do solo no período noturno foi aumentada em todos os tratamentos. Não houve mudança no fluxo de metano. No segundo experimento, utilizando a gramínea $\mathrm{C}_{4}$, a biomassa de folhas sofreu aumento no tratamento combinado eC+eT, o NEE diurno aumentou sob eC e a respiração do solo noturno aumentou sob eC+eT. No terceiro 
experimento, também utilizando a gramínea $\mathrm{C}_{4}$, porém, com tratamentos de restrição hídrica e elevada temperatura, não foram observadas diferenças nos dados coletados. De maneira geral, as mudanças climáticas trarão alterações no ciclo do carbono dos ecossistemas de pastagem, sendo que a utilização da leguminosa $\mathrm{C}_{3} S$. capitata pode acarretar em perdas de produtividade de folhagem e aceleração da fenologia. Já a gramínea $\mathrm{C}_{4} P$. maximum se mostrou resistente a um clima futuro de seca e temperatura elevada e se beneficiou da maior $\left[\mathrm{CO}_{2}\right]$, com maior fixação de carbono pelo ecossistema e produção de biomassa de folhas, sendo assim uma boa opção para a produção de forragem em pastagens tropicais.

Palavras-chaves: Aquecimento. Elevado $\mathrm{CO}_{2}$. Restrição hídrica. Forrageira tropical. Produtividade. 


\begin{abstract}
BOSSAN, V. P. Evaluation of the carbon cycle in tropical pasture ecosystems in future climate change scenario. 2017. 85f. Dissertation (Master's degree) - Faculdade de Filosofia, Ciências e Letras de Ribeirão Preto, Universidade de São Paulo, Ribeirão Preto, 2016.
\end{abstract}

Global warming and changes in the rain patterns are some of the changes observed in the weather of the planet in the last years. Simultaneously, it has been observed increases in the atmosphere's concentration of carbon dioxide $\left(\left[\mathrm{CO}_{2}\right]\right)$, mainly by anthropic actions. The rising $\left[\mathrm{CO}_{2}\right]$ and atmospheric temperature may intensify the greenhouse effect, modify the dynamic of plant gas exchange and the carbon cycle in the ecosystems. These changes occur by effects in the photosynthesis and respiration (auto and heterotrophic). Other factors, as soil moisture, may also affect these processes. Grasslands are ecosystems of importance to the humanity and of impact to the global carbon circle dynamic. Agriculture is the main anthropic land use and stores more than $10 \%$ of all carbon in the biosphere. With the aim of investigate the impact of climate changes in the dynamic of $\mathrm{CO}_{2}$ and carbon cycle in tropical grassland ecosystems, this work had as objective to quantify the production of biomass, the net flux of $\mathrm{CO}_{2}$ of the ecosystem (NEE), the soil respiration and methane flux in tropical grassland ecosystems. Two forage plant species, Panicum maximum Jacq. $\mathrm{Cv}$ Mombaça ( $\mathrm{C}_{4}$ grass), and Stylosanthes capitata Vogel ( $\mathrm{C}_{3}$ legume), were cultivated under elevated $\mathrm{CO}_{2}$ concentration $(600 \mu \mathrm{mol} \mathrm{mol}$ $\left.{ }^{1}\right)$, elevated atmospheric temperature $\left(+2{ }^{\circ} \mathrm{C}\right)$ and water shortage in a Free-air carbon dioxide enrichment (FACE) and Temperature free-air controlled enhancement (T-FACE) combined system. The NEE quantification was realized by open top chambers developed by the research group specifically for the integrated ecophysiological study of the whole canopy and not just a fraction of leaf area or the biomass, which are the most commonly used technics nowadays. In the experiment using the $\mathrm{C}_{3}$ legume was observed a decrease in total above-ground biomass, by the reduction of leaf biomass, in treatment with elevated temperature (eT) and an increase of stems biomass in the combined treatment of elevated $\left[\mathrm{CO}_{2}\right]$ and temperature $(\mathrm{eC}+\mathrm{eT})$. The diurnal NEE increased under elevated $\left[\mathrm{CO}_{2}\right](\mathrm{eC})$. The night soil respiration was increased in all three treatments. There were no changes in the methane flux. In the second experiment, utilizing the $\mathrm{C}_{4}$ grass, the leaves biomass increased under eC+eT, the diurnal NEE increased in the $\mathrm{eC}$ treatment and the night soil respiration also increased under $\mathrm{eC}+\mathrm{eT}$. In the third experiment, with the same $\mathrm{C}_{4}$, however, with water shortage and elevated temperature 
treatments, there were no differences in the collected data. Overall, the climate changes will bring alterations in the carbon cycle of grassland ecosystems, therefore, the use of the $\mathrm{C}_{3}$ legume S. capitata might entail in losses in foliage productivity and phenology acceleration. On the other hand, the $\mathrm{C}_{4}$ grass $P$. maximum showed resistance to a future climate with drought and elevated temperature, and benefited from the higher $\left[\mathrm{CO}_{2}\right]$, with greater carbon fixation by the ecosystem and production of leaf biomass, being a good option for forage production in tropical pastures.

Keywords: Heating. Elevated $\mathrm{CO}_{2}$. Water shortage. Tropical forage. Productivity. 


\section{LISTA DE FIGURAS}

Figura 1: Imagem de satélite da área experimental localizada no campus da USP em Ribeirão Preto (coordenadas $21^{\circ} 10^{\prime} 8.35^{\prime \prime S} 47^{\circ} 51^{\prime} 49.59^{\prime \prime O}$ ). A área experimental encontra-se destacada pelo círculo vermelho. Fonte: Google Earth acessado em 28/06/2017.

Figura 2: Esquema (vista aérea) da distribuição das parcelas experimentais com sistema FACE e T-FACE instalado na USP/RP. No sistema FACE, as parcelas com elevada concentração de $\mathrm{CO}_{2}$ recebem alimentação de $\mathrm{CO}_{2}$ puro a partir de um tanque criogênico de $\mathrm{CO}_{2}$ de 12 toneladas. No sistema T-FACE, cada parcela aquecida é controlada independentemente por meio de um painel elétrico conectado a sensores de temperatura e ao datalogger central. A energia elétrica para o sistema T-FACE é subministrada pela rede elétrica do campus da USP em Ribeirão Preto a partir de um transformador de $75 \mathrm{KVA}$ instalado especialmente para esse fim...................29

Figura 3: Vista geral da área experimental, com sistemas FACE e T-FACE instalados.

Figura 4: Ilustração esquemática da câmara de topo aberto (OTC), mostrando os componentes utilizados. No ducto de entrada de ar: a) filtro; b) anemômetro; c) ventoinha; d) IRGA. No ducto de saída de ar: e) filtro; f) ventoinha; g) IRGA; h) anemômetro.....

Figura 5: Esquema ilustrativo do campo experimental, evidenciando as 16 parcelas com tratamentos de elevada $\left[\mathrm{CO}_{2}\right]$, elevada temperatura e elevada $\left[\mathrm{CO}_{2}\right]+$ temperatura. As parcelas foram divididas em 4 blocos contendo as diferentes combinações de tratamento.

Figura 6: Médias diárias de temperatura do ar $\left({ }^{\circ} \mathrm{C}\right)$, umidade relativa do ar $(\%)$ e precipitação $(\mathrm{mm})$ registradas durante o período experimental com $S$. capitata em sistema T-FACE. As setas e bandas cinzas mostram as precipitações ocorridas durante o experimento e dias de chuvas consecutivos foram condensados. O experimento ocorreu de 24/04/2015 a 29/06/2015, totalizando 66 dias de tratamento. 36

Figura 7: (A) Biomassa de folhas, (B) biomassa de caules e (C) biomassa total acima do solo em $\mathrm{g} \mathrm{m}^{-2}$ de $S$. capita ao final do experimento sob tratamentos combinados de $\left[\mathrm{CO}_{2}\right]$ ambiente $(\mathrm{aC}),\left[\mathrm{CO}_{2}\right]$ elevada $(\mathrm{eC})$, temperatura ambiente (aT), e temperatura elevada (eT) em sistema T-FACE.

Figura 8: (A) Fluxo líquido de carbono do ecossistema durante período diurno, medido às 12:00 horas, e (B) período noturno, medido às 21:00 horas, em $\mathrm{mg}$ de carbono $\mathrm{m}^{-2} \mathrm{~s}^{-1}$, utilizando câmara de topo aberto em $S$. capitata sob condições de ambiente $\left[\mathrm{CO}_{2}\right](\mathrm{aC})$, elevada $\left[\mathrm{CO}_{2}\right]$ (eC), temperatura ambiente (aT) e temperatura elevada (eT) em sistema T-FACE. Média \pm erro padrão.

Figura 9: (A) Respiração do solo durante o período diruno (12:00 horas) e (B) respiração do solo durante o período noturno (21:00 horas) em $\mathrm{mg}$ de carbono $\mathrm{m}^{-2} \mathrm{~s}^{-1}$. Medições realizadas em solo sem plantas, em condições de ambiente $\left[\mathrm{CO}_{2}\right](\mathrm{aC})$, elevada $\left[\mathrm{CO}_{2}\right](\mathrm{eC})$, temperatura ambiente (aT) e temperatura elevada (eT) em sistema T-FACE. Média \pm erro padrão. 
Figura 10: Fluxo de metano $\left(\mathrm{CH}_{4}\right)$ do solo em $\mathrm{mg}$ de carbono $\mathrm{m}^{-2} \mathrm{~h}^{-1}$ sob cultivo de $S$. capitata em condições de ambiente $\left[\mathrm{CO}_{2}\right](\mathrm{aC})$, elevada $\left[\mathrm{CO}_{2}\right](\mathrm{eC})$, temperatura ambiente $(\mathrm{aT})$ e temperatura elevada (eT) em sistema T-FACE. Média \pm erro padrão.

Figura 11: Esquema ilustrativo do campo experimental, evidenciando as 16 parcelas com tratamentos de elevada $\left[\mathrm{CO}_{2}\right]$, elevada temperatura e elevada $\left[\mathrm{CO}_{2}\right]+$ temperatura. As parcelas foram divididas em 4 blocos contendo as diferentes combinações de tratamento.

Figura 12: Médias diárias de temperatura do $\operatorname{ar}\left({ }^{\circ} \mathrm{C}\right)$, umidade relativa do ar $(\%)$ e precipitação (mm) registradas durante o período experimental com $P$. maximum em sistema T-FACE. As setas e bandas cinzas mostram as precipitações ocorridas durante o experimento e dias de chuvas consecutivos foram condensados. O experimento ocorreu de 19/11/2015 a 18/12/2015, totalizando 29 dias de tratamento.

Figura 13: (A) Biomassa de folhas, (B) biomassa de caules e (C) biomassa total acima do solo $\mathrm{em} \mathrm{g} \mathrm{m}^{-2}$ de $P$. maximum ao final do experimento sob tratamentos combinados de $\left[\mathrm{CO}_{2}\right]$ ambiente $(\mathrm{aC}),\left[\mathrm{CO}_{2}\right]$ elevada $(\mathrm{eC})$, temperatura ambiente $(\mathrm{aT})$, e temperatura elevada (eT) em sistema T-FACE.

Figura 14: (A) Fluxo líquido de carbono do ecossistema durante período diurno, medido às 12:00 horas, $\mathrm{e}(\mathrm{B})$ período noturno, medido às 21:00 horas, em $\mathrm{mg}$ de carbono $\mathrm{m}^{-2} \mathrm{~s}^{-1}$, utilizando câmara de topo aberto em $P$. maximum sob condições de ambiente $\left[\mathrm{CO}_{2}\right](\mathrm{aC})$, elevada $\left[\mathrm{CO}_{2}\right]$ (eC), temperatura ambiente (aT) e temperatura elevada (eT) em sistema T-FACE. Média \pm erro padrão.

Figura 15: (A) Respiração do solo durante o período luminoso (12:00 horas) e (B) respiração do solo durante o período noturno (21:00 horas) em mg de carbono $\mathrm{m}^{-2} \mathrm{~s}^{-1}$. Medições realizadas em solo sem plantas, em condições de ambiente $\left[\mathrm{CO}_{2}\right](\mathrm{aC})$, elevada $\left[\mathrm{CO}_{2}\right](\mathrm{eC})$, temperatura ambiente (aT) e temperatura elevada (eT) em sistema T-FACE. Média \pm erro padrão.

Figura 16: Fluxo de metano $\left(\mathrm{CH}_{4}\right)$ do solo em $\mathrm{mg} \mathrm{C} \mathrm{m}^{-2} \mathrm{~h}^{-1}$ sob cultivo de $P$. maximum em condições de ambiente $\left[\mathrm{CO}_{2}\right](\mathrm{aC})$, elevada $\left[\mathrm{CO}_{2}\right](\mathrm{eC})$, temperatura ambiente $(\mathrm{aT})$ e temperatura elevada (eT) em sistema T-FACE. Média \pm erro padrão.

Figura 17: Esquema ilustrativo do campo experimental, evidenciando as 16 parcelas com tratamentos de restrição hídrica, elevada temperatura e restrição hídrica + temperatura. As parcelas foram divididas em 4 blocos contendo as diferentes combinações de tratamento..... 62

Figura 18: Médias diárias de temperatura do $\operatorname{ar}\left({ }^{\circ} \mathrm{C}\right)$, umidade relativa do ar $(\%)$ e precipitação $(\mathrm{mm})$ registradas durante o período experimental com P. maximum em sistema T-FACE. As setas e bandas cinzas mostram as precipitações ocorridas durante o experimento e dias de chuvas consecutivos foram condensados. O experimento ocorreu de 06/11/2016 a 19/12/2016, totalizando 43 dias de tratamento.

Figura 19: Conteúdo médio de água no solo $\left(\mathrm{m}^{3} \mathrm{~m}^{-3}\right)$ em cada tratamento ao longo do período experimental. O limite $\left(0,45 \mathrm{~m}^{3} \cdot \mathrm{m}^{-3}\right)$ utilizado para controlar a rega das parcelas sob disponibilidade hídrica está indicado no gráfico pela reta cinza. Durante 2 dias (25/11 e 26/11) os sensores falharam e marcaram valores não reais, não são apresentados os valores desse período no gráfico. Tratamentos: dH+aT: Disponibilidade Hídrica + Temperatura Ambiente; 
rH+aT: Restrição Hídrica + Temperatura Ambiente; dH+eT: Disponibilidade Hídrica + Elevada Temperatura; $\mathrm{rH}+\mathrm{eT}$ : Restrição Hídrica + Elevada Temperatura.

Figura 20: Média do conteúdo de água no solo $\left(\mathrm{m}^{3} \mathrm{~m}^{-3}\right)$ durante o período experimental nas parcelas com disponibilidade hídrica $(\mathrm{dH})$ e com restrição hídrica $(\mathrm{rH})$. Os dados de umidade do solo foram coletados de hora em hora em todas as parcelas durante todo o período experimental.

Figura 21: A) Biomassa de folhas, (B) biomassa de caules e (C) biomassa total acima do solo em $\mathrm{g} \mathrm{m}^{-2}$ de $P$. maximum ao final do experimento sob tratamentos combinados de restrição hídrica $(\mathrm{rH})$, disponibilidade hídrica $(\mathrm{dH})$, temperatura ambiente $(\mathrm{aT})$, e temperatura elevada (eT) em sistema T-FACE.

Figura 22: (A) Fluxo líquido de carbono do ecossistema durante período luminoso, medido às

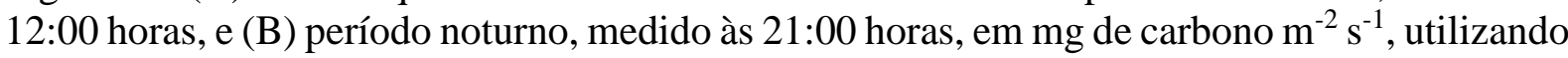
câmara de topo aberto em $P$. maximum sob condições de restrição hídrica $(\mathrm{rH})$, disponibilidade hídrica $(\mathrm{dH})$, temperatura ambiente $(\mathrm{aT})$ e temperatura elevada (eT) em sistema T-FACE. Média \pm erro padrão.

Figura 23: (A) Respiração do solo durante o período luminoso (12:00 horas) e (B) respiração do solo durante o período noturno (21:00 horas) em $\mathrm{mg}$ de carbono $\mathrm{m}^{-2} \mathrm{~s}^{-1}$. Medições realizadas em solo sem plantas, em condições de restrição hídrica $(\mathrm{rH})$, disponibilidade hídrica $(\mathrm{dH})$, temperatura ambiente (aT) e temperatura elevada (eT) em sistema T-FACE. Média \pm erro padrão.

Figura 24: Fluxo de metano $\left(\mathrm{CH}_{4}\right)$ do solo em $\mathrm{mg} \mathrm{C} \mathrm{m}^{-2} \mathrm{~h}^{-1}$ sob cultivo de $P$. maximum em condições de restrição hídrica $(\mathrm{rH})$, disponibilidade hídrica $(\mathrm{dH})$, temperatura ambiente $(\mathrm{aT})$ e temperatura elevada (eT), em sistema T-FACE. Média \pm erro padrão. 


\section{LISTA DE TABELAS}

Tabela 1: Dados abióticos coletados durante os períodos experimentais

Tabela 2: Dados bióticos coletados durante os períodos experimentais. .75 


\section{SUMÁRO}

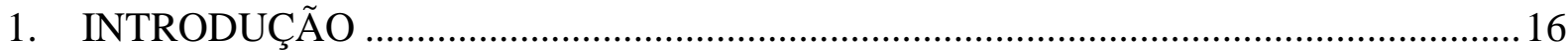

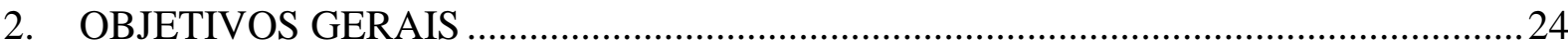

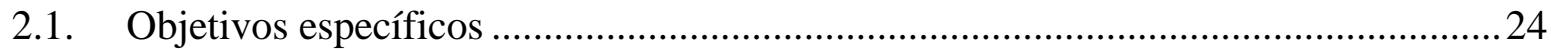

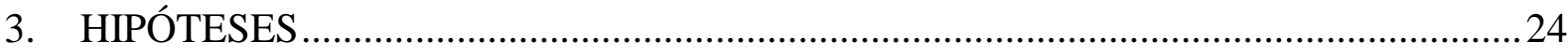

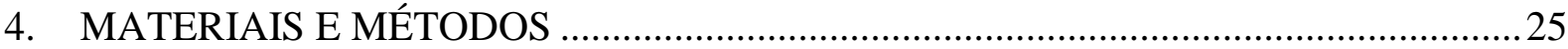

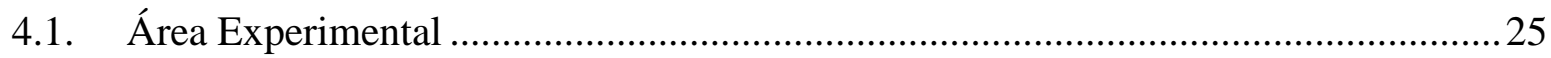

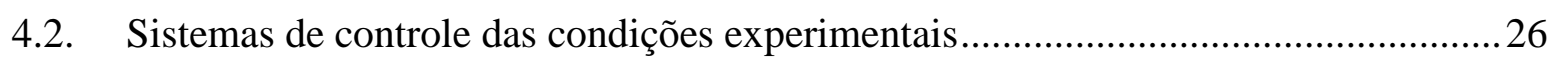

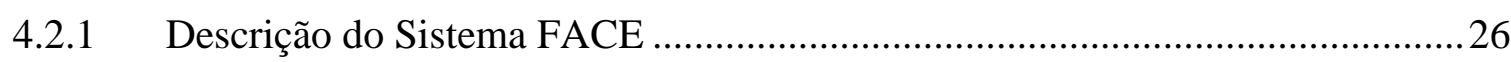

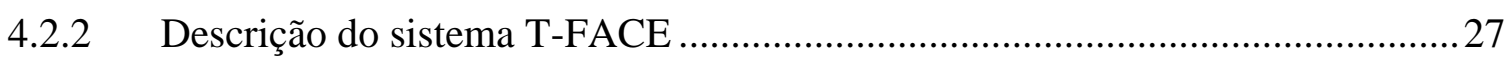

4.3. Câmara de Topo Aberto e Fluxo Líquido de $\mathrm{CO}_{2}$ do Ecossistema (NEE) ................ 30

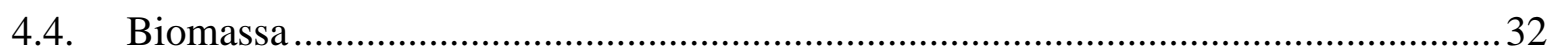

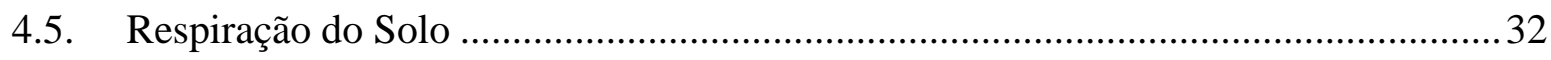

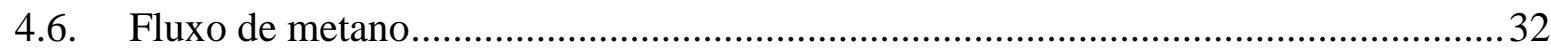

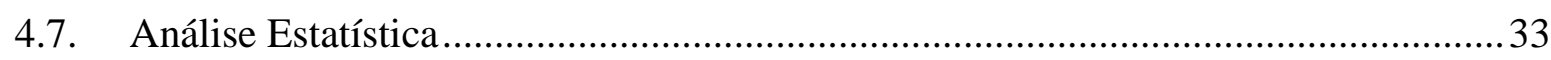

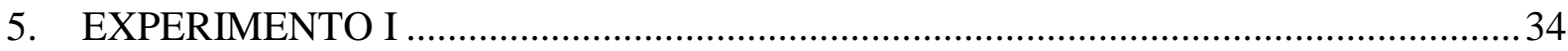

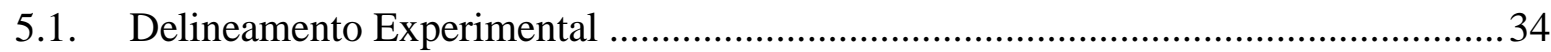

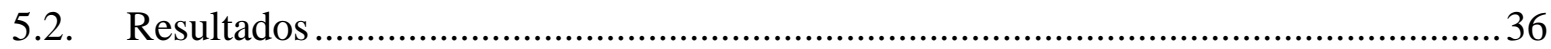

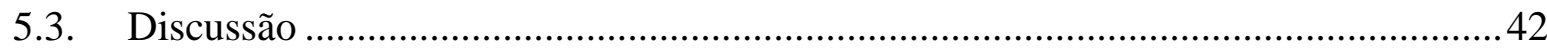

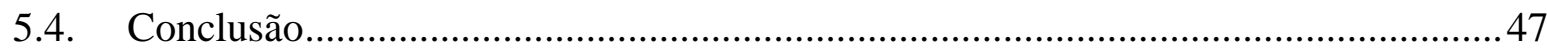

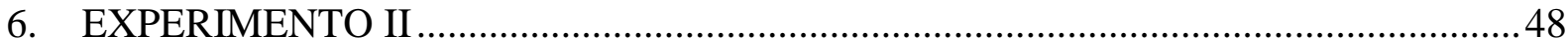

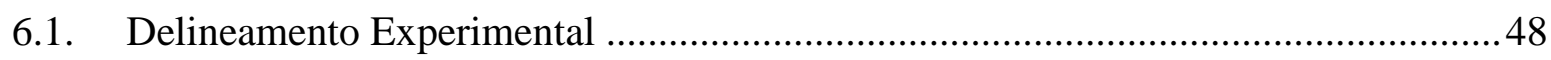

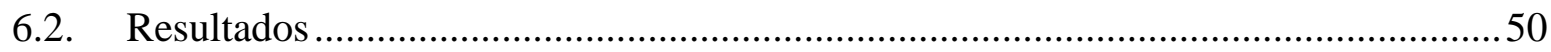

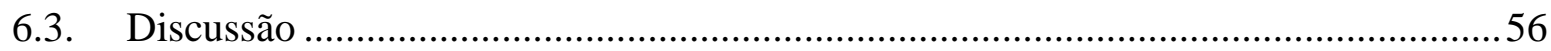

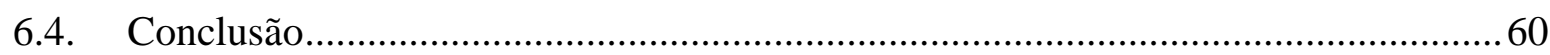

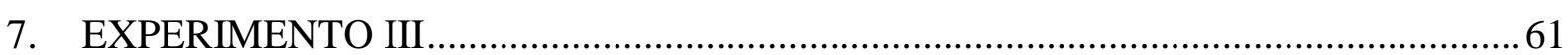

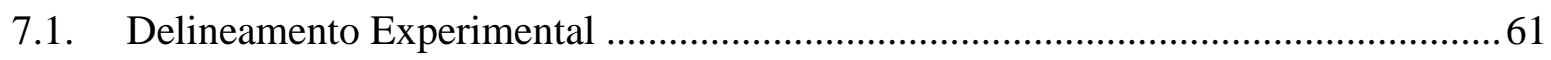

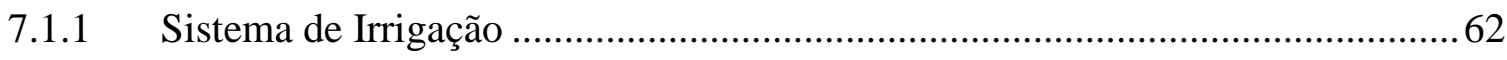

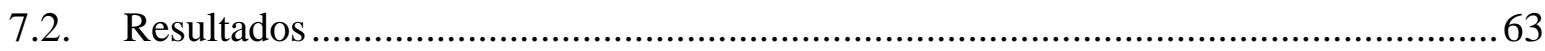

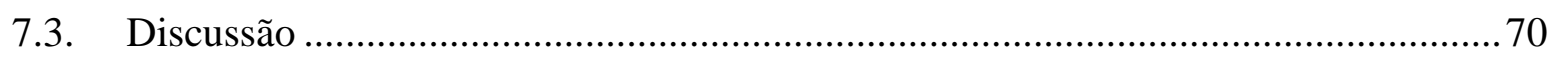

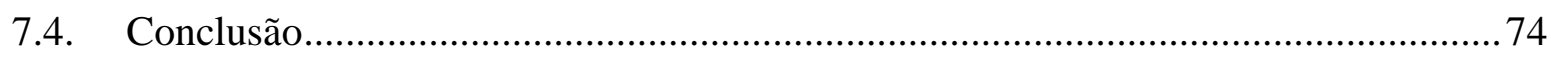

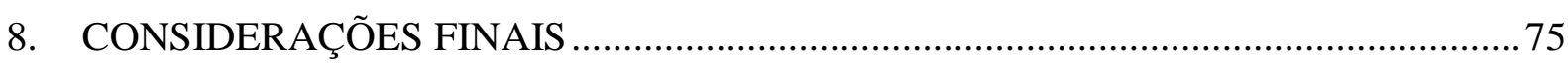

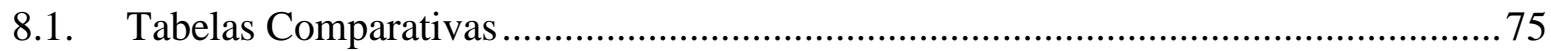

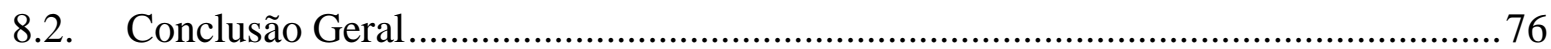

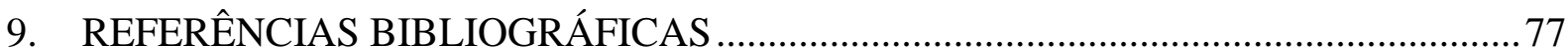




\section{INTRODUÇÃO}

Com a revolução industrial do século XVIII, houve um constante incremento nas emissões de gás carbônico $\left(\mathrm{CO}_{2}\right)$ e outros gases como o metano $\left(\mathrm{CH}_{4}\right)$ e óxido nitroso $\left(\mathrm{N}_{2} \mathrm{O}\right)$. Por possuírem a capacidade de reter considerável quantia de energia em forma de calor a ponto de alterar a temperatura atmosférica global, esses gases foram denominados de gases efeito estufa (GEEs). O aumento populacional, a mudança no uso da terra e, principalmente, a queima de combustíveis fósseis, foram e continuam sendo fatores antrópicos que influenciaram o aumento da concentração global de GEEs observado nos últimos 200 anos (IPCC, 2014).

$\mathrm{O}$ aumento na concentração atmosférica destes gases tem causado elevação na temperatura média global, desencadeando outros efeitos influenciados por essa variável, como por exemplo, variabilidade nos padrões de precipitação, eventos naturais extremos e intensificação de secas. A concentração de $\mathrm{CO}_{2}\left(\left[\mathrm{CO}_{2}\right]\right)$ na atmosfera passou de 280 partes por milhão (ppm) no início do século XVIII, para 400 ppm no início do século XXI. Além disso, prevê-se que no futuro essas concentrações possam chegar a 600 ppm em 2050 e entre 800 e 1000 ppm até 2100. Consequentemente, são previstos incrementos na temperatura média global que variam de 2 a $4^{\circ} \mathrm{C}$, podendo causar mudanças climáticas de impacto global nunca antes observadas neste curto período de tempo (BARKER, 2007; IPCC, 2014; LAL, 2008; PORTER et al., 2014).

As plantas desempenham papel crucial para a sobrevivência e desenvolvimento não só da espécie humana, mas de toda a vida na Terra. Por meio de suas atividades fisiológicas, notadamente a fotossíntese, as plantas são capazes de absorver e transformar radiação solar, $\mathrm{CO}_{2}$ e água em energia fotoquímica, oxigênio $\left(\mathrm{O}_{2}\right)$ e matéria orgânica, utilizada como alimento pelos seres vivos ou matéria prima para a indústria e outras atividades humanas. A fotossíntese é um processo bioquímico que requer basicamente $\mathrm{CO}_{2}$, luz, água e nutrientes minerais, gerando como produtos finais, água, $\mathrm{O}_{2}$ e açúcares. Portanto, tanto o contexto biótico quanto o abiótico possuem papéis decisivos na taxa fotossintética das plantas e suas interações ecológicas nos ecossistemas (TAIZ; ZEIGER, 2006).

Uma vez que as plantas utilizam diretamente $\mathrm{CO}_{2}$, luz, nutrientes e água em seus processos biológicos, é esperado que sejam alguns dos primeiros organismos afetados pelas mudanças climáticas de magnitudes e consequências globais. Diante desse cenário, presume-se que os ecossistemas terrestres apresentem mudanças em seus microclimas e biodiversidade num futuro próximo (HANSEN et al., 2001; PARMESAN et al., 2003; TAIZ; ZEIGER, 2006).

Tanto em ecossistemas naturais quanto em áreas manejadas pelo homem, as plantas possuem papel fundamental para seu funcionamento, além de grande importância econômica. 
Isso porque são produtores primários formando a base das cadeias alimentares terrestres e proporcionam diversos serviços ambientais e sociais, como a segurança alimentar (CHAKRABORTY; NEWTON, 2011).

As pastagens constituem um dos mais importantes e complexos ecossistemas, além de serem a forma mais ampla do uso do solo pelo homem, sendo um dos principais responsáveis pela segurança alimentar da população mundial, e conterem mais de $10 \%$ do carbono armazenado na biosfera (BONDEAU et al., 2007). No Brasil, são mais de 150 milhões de hectares de pastagens, cerca de $18 \%$ do território nacional, majoritariamente para produção extensiva de gado de corte ou leite, uma vez que $90 \%$ dos alimentos desses animais provém da biomassa de forrageiras de pastagens naturais ou cultivadas (FERRAZ; FELÍCIO, 2010). As mudanças climáticas terão efeitos significativos sobre o fluxo do carbono e produtividade nesses ecossistemas, e no papel das pastagens como sumidouro de carbono. Por esta razão, cientistas estudam os possíveis impactos das mudanças climáticas nos sistemas agrícolas e no funcionamento dos ecossistemas relacionados (IPCC, 2014; LONG et al., 2005, 2006).

Dentre os parâmetros fisiológicos, a fotossíntese e a respiração são comumente estudados com o intuito de avaliar a eficiência da captura do carbono atmosférico para o crescimento, manutenção e acúmulo de biomassa pelas plantas. A quantidade total de carbono assimilado através da fotossíntese (produtividade primária bruta, GPP), menos a quantidade de carbono liberado, pela respiração autotrófica, é chamada produtividade primaria líquida (NPP).

Parte do substrato produzido pela fotossíntese é utilizado na geração de energia, pela quebra de moléculas de ATP, no processo chamado de respiração celular. Esse processo devolve para a atmosfera uma fração do $\mathrm{CO}_{2}$ assimilado na fotossíntese. Para estudos ecofisiológicos, a respiração vegetal é dividida em respiração autotrófica acima do solo, proveniente principalmente de caules, folhas e flores, e respiração autotrófica abaixo do solo, proveniente de raízes (TAIZ; ZEIGER, 2006).

Existem ainda outras maneiras as quais o carbono pode voltar para a atmosfera. Principalmente pela atividade da microbiota do solo, através da respiração heterotrófica de fungos e bactérias (decomposição de matéria orgânica) e do metabolismo anaeróbico de bactérias metanogênicas. É estimado que a respiração total do planeta Terra seja de aproximadamente $117 \mathrm{Pg}$ de carbono por ano, dos quais $60 \mathrm{Pg}$ são provenientes da respiração autotrófica e 57 Pg da respiração heterotrófica (DAVIDSON; JANSSENS, 2006). No entanto, esses valores podem variar de acordo com as características temporais, climáticas e espaciais de cada ecossistema. Chambers et al. (2014) estimaram em um ecossistema de floresta tropical, 
a contribuição anual média de respiração autotrófica das porções acima do solo, abaixo do solo, e heterotrófica de 52, 19 e 29\%, respectivamente (CHAMBERS et al., 2014). Já em um ecossistema de savana no norte da Austrália, Chen et al. (2003) relataram que as contribuições de respiração autotrófica acima do solo, abaixo do solo, e heterotrófica foram de 16, 42 e 42\%, respectivamente (CHEN; HUTLEY; EAMUS, 2003). Isso quer dizer que em um ecossistema de pastagem, a respiração do solo (autotrófica + heterotrófica) passa a ser mais importante que a respiração acima do solo.

A fotossíntese e a respiração são complexos processos bioquímicos de trocas gasosas entre a planta e a atmosfera e, devido à sua importância e aplicabilidade, vem sendo estudados há muitos anos. Com os conhecimentos já adquiridos é sabido que, sob a atual concentração atmosférica de $\mathrm{CO}_{2}$, cerca de 400 ppm, a adição de carbono à ribulose-1,5-bisfosfato (RuBP) por meio da enzima Ribulose-1,5-bisfostato carboxilase/oxigenase (Rubisco) é o maior limitante da fotossíntese. No entanto, o incremento da concentração de $\mathrm{CO}_{2}$ na atmosfera ligado ao aumento da temperatura podem interagir, aumentando o potencial fotossintético e, consequentemente, as taxas fotossintéticas e o fluxo de carbono no ecossistema (LONG et al., 2006).

Além disso, existe uma diferença entre espécies com metabolismo fotossintético $\mathrm{C}_{3}$ e $\mathrm{C}_{4}$ em resposta ao aumento da $\left[\mathrm{CO}_{2}\right]$ na atmosfera. Embora possuam temperatura ótima para fotossíntese mais elevada, espécies de plantas com metabolismo $\mathrm{C}_{4}$ são menos beneficiadas pelo aumento do $\mathrm{CO}_{2}$ do que as $\mathrm{C}_{3}$, pois possuem uma estrutura anatômica de bombeamento ativo de $\mathrm{CO}_{2}$ das células do mesofilo para as células da bainha, aumentando a concentração de $\mathrm{CO}_{2}$ disponível para a atividade enzimática da Rubisco como carboxilase (DUKES; MOONEY, 1999; TAIZ; ZEIGER, 2006).

Essa estrutura, conhecida como Kranz, também diminui o efeito negativo de elevadas temperaturas para a fotossíntese. Em alta temperatura, a Rubisco tende a ter uma atividade oxidativa maior, aumentando assim a fotorrespiração, processo no qual em vez de $\mathrm{CO}_{2}$ a Rubisco se liga a uma molécula de $\mathrm{O}_{2}$, desencadeando um processo que resulta na liberação de $\mathrm{CO}_{2}$ para a atmosfera e diminui a eficiência fotossintética, uma vez que essa molécula de Rubisco poderia estar trabalhando como carboxilase e gerando substrato para a fotossíntese. No entanto, a estrutura Kranz diminui a concentração de $\mathrm{O}_{2}$ e aumenta a de $\mathrm{CO}_{2}$ nas células da bainha, assim, a Rubisco, mesmo trabalhando em altas temperaturas, tende a se ligar com o $\mathrm{CO}_{2}$ (LARA; ANDREO, 2011). 
As mudanças climáticas potencialmente afetam a forma como o carbono passa pelos ecossistemas de pastagens, desde a entrada, através da fotossíntese, a temporária permanência em forma de biomassa e eventual permanência mais duradoura no solo na forma de matéria orgânica até seu retorno à atmosfera pela respiração auto e heterotrófica, metabolismo microbiológico e decomposição da matéria orgânica (PARMESAN et al., 2003).

A compreensão de como esses processos se darão no futuro, principalmente para modelagens em conjunto com outros parâmetros físicos, é essencial para desvendar o potencial de adaptação das espécies forrageiras às mudanças climáticas; relacionar esse potencial com a produtividade e manejo das mesmas pela agropecuária; e entender o potencial de mitigação dos efeitos das mudanças climáticas pelas pastagens, por meio do sequestro de carbono (CLARK et al., 2001; NORBY et al., 1999).

A quantidade total de carbono estocada no ecossistema depende principalmente da biomassa vegetal, que, por sua vez, é dependente do crescimento, definido como incorporação de carbono ao tecido vegetal, seja para divisão celular, para extensão celular, aumento no número de folhas, ramos ou raízes, armazenamento e produção de compostos carbônicos, como óleos e resinas. Cada um desses processos tem uma demanda específica por carbono, o que leva a uma mudança permanente na forma da planta e são controlados internamente, mas influenciados pelo meio externo (SHARKEY, 2015).

Tanto as práticas de manejo, como a fertilização do solo, a rotação do pastejo ou consórcio com outras espécies, quanto as variáveis ambientais, como o tipo de solo, umidade do solo, temperatura e intensidade luminosa, são exemplos de influências exteriores na demanda e partição de carbono. As variações ambientais podem afetar o crescimento mudando os padrões de assimilação e alocação do carbono.

Elevadas concentrações de $\mathrm{CO}_{2}$ podem, por exemplo, alterar o crescimento, e aumentar o acúmulo de biomassa acima e abaixo do solo (AINSWORTH; LONG, 2005). Em uma metaanálise de estudos dos efeitos da elevada $\left[\mathrm{CO}_{2}\right]$ em sistemas abertos por enriquecimento de $\mathrm{CO}_{2}$ ao ar livre (FACE, do inglês Free Air $\mathrm{CO}_{2}$ Enrichment), Ainsworth e Long (2005) descreveram um aumento de $20 \%$ na biomassa e produtividade de espécies $\mathrm{C}_{3}$ e cerca de $5 \%$ em espécies $\mathrm{C}_{4}$ (AINSWORTH; LONG, 2005).

Em pastagens temperadas, compostas por espécies de metabolismo $\mathrm{C}_{3}$ e $\mathrm{C}_{4}$, o aumento da temperatura em $2.8^{\circ} \mathrm{C}$ aumentou a produtividade primária bruta do ecossistema, embora tenha aumentado também a respiração. Isso significa que o fluxo de carbono no ecossistema pode ser alterado, por mudanças na fixação e liberação do carbono (NIU et al., 2013). Apesar da sua 
importância, estes tipos de avaliações ainda são raras em pastagens tropicais. Além do mais, técnicas específicas de manejo, como o pastejo em rotação extensiva, podem interferir na resposta das pastagens às mudanças climáticas previstas.

O aumento da temperatura atmosférica pode acelerar a fenologia das plantas, modificando a demanda por carbono e também o uso da água em ecossistemas compostos por plantas $\mathrm{C}_{3} \mathrm{e}$ $\mathrm{C}_{4}$ (AIRES; PIO; PEREIRA, 2008; NIU et al., 2013). Além disso, o aumento da temperatura reduz a afinidade da enzima Rubisco pelo carbono mais do que pelo oxigênio, induzindo maiores taxas de fotorespiração (AINSWORTH; ROGERS, 2007; SAGE; KUBIEN, 2007).

A respiração total do ecossistema tende a aumentar sob elevada temperatura, resultando em mais carbono liberado para a atmosfera (SAGE; KUBIEN, 2007). No entanto, ainda existem dúvidas na relação entre as taxas respiratórias nas plantas e o aumento da concentração de $\mathrm{CO}_{2}$ na atmosfera. Isso porque existem resultados contrastantes reportados na literatura. Já foram observadas reduções, aumentos e nenhum efeito na taxa respiratória de plantas e ecossistemas em experimentos com elevadas [ $\mathrm{CO}_{2}$ ] (GONZALEZ-MELER; TANEVA; TRUEMAN, 2004).

A respiração do solo é um importante fator na respiração total do ecossistema e no fluxo de $\mathrm{CO}_{2}$ do ciclo do carbono, apesar disso, seus componentes (respiração heterotrófica, respiração autotrófica abaixo do solo e decomposição de matéria orgânica) ainda são pouco compreendidos (GOMEZ-CASANOVAS et al., 2012; TANEVA; GONZALEZ-MELER, 2011). Ainda há pouca informação sobre respiração em escala de ecossistema, no entanto, um estudo em pradarias mostrou que a interação entre a produtividade primária bruta e a umidade do solo é a principal responsável pelo fluxo de carbono autotrófico do solo, enquanto que a interação entre a produtividade primária bruta e a temperatura explica as variações nos componentes heterotróficos da respiração do solo, ambos de forma direta, ou seja, o aumento na GPP, umidade do solo e temperatura tendem a aumentar a respiração do solo (GOMEZCASANOVAS et al., 2012). Já o metano $\left(\mathrm{CH}_{4}\right)$, produzido e consumido por bactérias do solo, tende a ser produzido em maior escala em solos com menor umidade e temperatura elevada, ou em condições de hipóxia do solo, como em plantações de arroz (TOPP; PATTEY, 1997).

Os processos que ocorrem dentro dos tecidos vegetais, como folhas, caules, raízes e flores, não podem ser especificamente acessados em termos bioquímicos de forma prática. Porém, é possível modelar a taxa fotossintética e a respiração auto e heterotrófica dos ecossistemas, processos centrais de fixação e perda de carbono pelo meio biótico, a partir de parâmetros físicos como dinâmica de trocas gasosas $\left(\mathrm{CO}_{2}, \mathrm{CH}_{4}, \mathrm{H}_{2} \mathrm{O}, \mathrm{N}_{2} \mathrm{O}\right.$, entre outros), área foliar, luz e temperatura (EL-SHARKAWY, 2011). 
Uma das maneiras de se quantificar esses processos é pelo balanço de gases entre a planta e a atmosfera em um determinado período de tempo. Dessa forma, pela diferença entre a concentração inicial/entrada e final/saída dos gases no sistema planta-atmosfera é possível estimar as taxas de fotossíntese e respiração (HUNT, 2003).

$\mathrm{O}$ método mais utilizado para medir as trocas gasosas em plantas, envolve o uso de aparelhos portáteis com analisadores de gases por infravermelho (IRGA) para quantificar o carbono assimilado pela fotossíntese e liberado pela respiração ou água perdida pela transpiração. Esses aparelhos fazem medições em folhas, com pequenas áreas de amostragem, que variam de 1 a $6 \mathrm{~cm}^{2}$. No entanto, sistemas que permitam fazer a medição das trocas gasosas em plantas inteiras e do ecossistema ainda são raros e podem gerar informações relevantes quanto a ecofisiologia e a dinâmica do carbono no ambiente de forma holística (HUNT, 2003; MILLAN-ALMARAZ et al., 2009; UPRETY et al., 2006).

A maior parte dos aparelhos, e consequentemente dos dados gerados, utilizados para acessar a assimilação de carbono pelas plantas se baseiam em valores específicos e limitados, por abrangerem apenas uma ou mais folhas, que possuem grande variabilidade quando comparadas com o indivíduo como um todo e ainda mais em uma escala ecossistêmica. Essas variações são provenientes principalmente de diferenças na receptação de radiação, déficit de pressão de água e características fisiológicas particulares de cada órgão, como estágio fenológico, concentração de amido e estado do fotossistema (MARUR, C. J.; FARIA, 2006).

Apesar dos métodos de análise foliar serem eficientes para estudos de processos específicos da fisiologia das plantas, é perdida a capacidade de representar com precisão os processos ecossistêmicos, como a fotossíntese líquida do ecossistema ou o fluxo líquido de carbono no ecossistema (NEE), que integra a fotossíntese bruta, a respiração autotrófica acima do solo e a respiração do solo. A vantagem de medições do NEE é a obtenção de dados de taxa de carbono assimilado ou perdido pelo ecossistema em um período de forma direta. Essa é uma informação importante sobre como o ciclo do carbono se comporta no ecossistema em diferentes tratamentos ambientais (HUNT, 2003; MARUR; FARIA, 2007).

Existem diversos métodos de estudar os impactos da elevada $\left[\mathrm{CO}_{2}\right]$ em plantas, utilizando, por exemplo, câmaras de crescimento, câmaras com ambiente controlado, estufas, câmaras de topo aberto e instalações de enriquecimento de $\mathrm{CO}_{2}$ ao ar livre (FACE) (KIMBALL et al., 1997; LONG; DRAKE, 1991; UPRETY et al., 2006).

Os primeiros estudos com elevada $\left[\mathrm{CO}_{2}\right]$ em plantas foram realizados em sistemas isolados, utilizando câmaras com ambiente controlado, pela facilidade de controlar as variáveis 
ambientais e disposição dos aparelhos na época. Estes estudos ainda formam a base dos conhecimentos atuais sobre as respostas das plantas às diferentes [CO 2 (CURTIS, 1996; NORBY et al., 1999).

No entanto, nos sistemas isolados, as condições microclimáticas simuladas não são as mesmas do campo aberto, o que dificulta a modelagem dos processos biológicos e podem causar perdas na acurácia dos estudos. Os sistemas isolados produzem um "efeito de câmara", que pode modificar a dinâmica do carbono nas plantas, por afetar a resposta estomática, as taxas fotossintéticas e a produtividade da planta, principalmente devido ao aumento da temperatura e umidade relativa do ar no interior da câmara. Além disso, estes sistemas modificam as interações ecológicas das plantas com o meio em que vivem em ambiente natural (MILLANALMARAZ et al., 2009; MORGAN et al., 2001).

Para reduzir as limitações experimentais inerentes aos sistemas fechados na simulação dos efeitos das mudanças climáticas, surgiu a necessidade da criação de um sistema a céu aberto. Assim, o sistema FACE de injeção e enriquecimento da $\left[\mathrm{CO}_{2}\right]$ a céu aberto foi desenvolvido. Neste novo sistema, as plantas são cultivadas em ambiente aberto sob condições naturais, sendo que a fumigação com $\mathrm{CO}_{2}$ ocorre por tubos que liberam o gás puro ao redor da área tratada e utilizam-se do vento e da difusão natural do ambiente para dispersar o gás pela área experimental (AINSWORTH; LONG, 2005; LONG et al., 2005).

Afim de melhor entender os possíveis efeitos das mudanças climáticas nas plantas previstas para o próximo século, foram executados na USP/RP os projeto temáticos FAPESP "Experimento miniFACE para analisar os efeitos do elevado $\mathrm{CO}_{2}$ e do aquecimento sobre a fotossíntese, expressão gênica, bioquímica, crescimento, dinâmica de nutrientes e produtividade de duas espécies forrageiras tropicais contrastantes" e MCTI/CNPq/ANA “Impacto Do Aquecimento e da Deficiência Hídrica No Desempenho Molecular, Bioquímico, Fisiológico, Produtivo e Reprodutivo de Duas Espécies Forrageiras Tropicais", ambos coordenados pelo Prof. Dr. Carlos Alberto Martinez y Huaman.

Esses projetos foram estudos pioneiros no Brasil e ainda pouco difundido pelo mundo, que utilizaram diversas metodologias modernas como FACE e T-FACE para simular as condições de elevado $\mathrm{CO}_{2}$ e temperatura em um ambiente o mais próximo possível da realidade. $\mathrm{O}$ trabalho apresentado nesta dissertação se insere nestes projetos com o escopo investigativo das relações ecofisiológicas do ciclo do carbono nos ecossistemas de pastagem.

A elucidação das etapas do ciclo do carbono sob influência das mudanças climáticas permite estimar a produtividade das pastagens em um cenário climático futuro, acessar em qual nível o 
ciclo carbono nos ecossistemas de pastagem será afetado pelas mudanças climáticas e quais as possíveis implicações para a agropecuária tropical e para o planeta Terra. 


\section{OBJETIVOS GERAIS}

Este trabalho teve como objetivos avaliar o fluxo do carbono em dois ecossistemas de pastagem tropical, compostos por forrageiras $\mathrm{C}_{3}$, Stylosanthes capitata Vogel (S. capitata), e $\mathrm{C}_{4}$, Panicum maximum jaq. $\mathrm{Cv}$ Mombaça (P. maximum) em ambientes simulados de mudanças climáticas, com tratamentos de elevada $\left[\mathrm{CO}_{2}\right]$ (50\% acima do ambiente), restrição hídrica e elevada temperatura $\left(2^{\circ} \mathrm{C}\right.$ acima do ambiente).

\subsection{Objetivos específicos}

Os objetivos específicos deste trabalho foram avaliar a influência dos tratamentos na:

$>$ Biomassa de folhas, caules e total acima do solo;

$>$ Fluxo líquido de carbono do ecossistema (NEE), diurno e noturno;

> Respiração do solo, diurno e noturno;

$>$ Fluxo de metano no solo.

\section{HIPÓTESES}

As hipóteses propostas foram:

A biomassa e o NEE aumentam com a elevada $\mathrm{CO}_{2}$ por maior disponibilidade de substrato para a fotossíntese no caso da $\mathrm{C}_{3}$, e maior eficiência no uso do carbono e água no caso da $\mathrm{C}_{4}$.

A temperatura elevada não causará mudanças na biomassa e $\mathrm{NEE}$ da espécie $\mathrm{C}_{4}$, por sua resistência a altas temperaturas, porém, a espécie $\mathrm{C}_{3}$ não tem a mesma capacidade e, por isso, a sua biomassa e NEE diminuem sob elevada temperatura.

A restrição hídrica diminui a biomassa e NEE da espécie $\mathrm{C}_{4}$, devido a redução da taxa fotossintética, que leva a menor NEE e por fim menor biomassa.

$>$ A respiração do solo aumenta com a elevada $\left[\mathrm{CO}_{2}\right]$ e temperatura, em ambas as espécies, pois aumentam as atividades autotrófica e heterotrófica do solo. No entanto, a respiração do solo diminui com a restrição hídrica, pois diminui a atividade microbiológica e das raízes.

O metano é fixado no solo em maior taxa sob elevada $\left[\mathrm{CO}_{2}\right]$, temperatura e restrição hídrica, desde que em níveis não estressantes, pela maior atividade das bactérias metanotróficas e menor atividade anaeróbica produtora de metano. 


\section{MATERIAIS E MÉTODOS}

\section{1. Área Experimental}

O estudo foi realizado em uma área dentro do campus da Universidade de São Paulo, na cidade de Ribeirão Preto, São Paulo, Brasil. A área possuía $2500 \mathrm{~m}^{2}$, situada a 580 metros de altitude e coordenadas $21^{\circ} 10^{\prime} 8.35^{\prime \prime S} 47^{\circ} 51^{\prime} 49.59^{\prime \prime}$ (Figura 1). De acordo com a classificação climática de Köppen-Geiger, a região é do tipo climático Aw, que consiste em clima tropical megatérmico, com temperatura média do mês mais frio do ano superior a $18^{\circ} \mathrm{C}$, inverno seco e pouco definido ou ausente e forte precipitação anual. Entre 1961 e 2010, segundo dados históricos do Instituto Nacional de Meteorologia (INMET), houve na região uma precipitação anual média de $1446,36 \mathrm{~mm}$ e temperatura compensada mensal média de $21,95^{\circ} \mathrm{C}$, os dados foram adquiridos pela estação meteorológica de São Simão, a $47 \mathrm{Km}$ da área experimental (INMET, 2017). O solo da região é classificado como latossolo vermelho distrófico, por ser um solo mineral, homogêneo, sem diferenciação entre os horizontes, profundo, bem drenado, com baixa capacidade de troca de cátions e baixa fertilidade (KER, J. C., 1997).

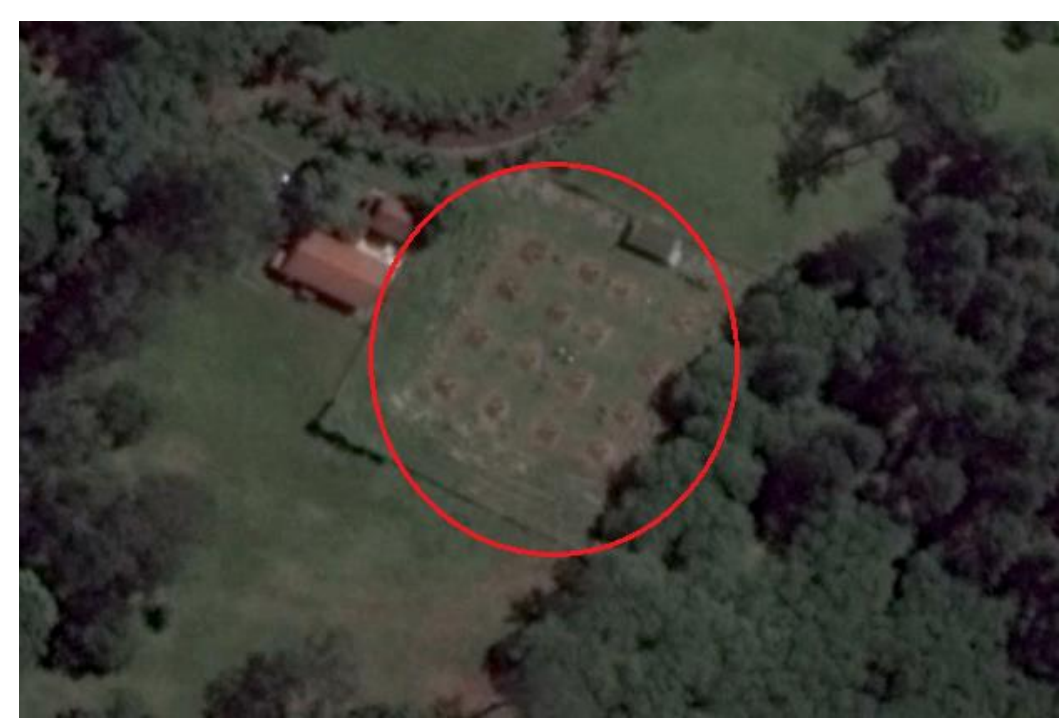

Figura 1: Imagem de satélite da área experimental localizada no campus da USP em Ribeirão Preto (coordenadas $21^{\circ} 10^{\prime} 8.35^{\prime \prime S} 47^{\circ} 51^{\prime} 49.59^{\prime \prime} \mathrm{O}$ ). A área experimental encontra-se destacada pelo círculo vermelho. Fonte: Google Earth acessado em 28/06/2017. 


\subsection{Sistemas de controle das condições experimentais}

Os experimentos foram realizados entre abril de 2015 e dezembro de 2016, sob condições de campo, utilizando os sistemas combinados FACE (Free-air carbon dioxide enrichment) e T-FACE (Temperature Free-air controlled enhancement) para controle das condições de concentração atmosférica de $\mathrm{CO}_{2}$ e temperatura atmosférica. Esses sistemas foram instalados para a execução do Projeto Temático FAPESP 08/58075-8, no campus da USP de Ribeirão Preto, São Paulo (Figuras 2 e 3).

\subsubsection{Descrição do Sistema FACE}

O sistema de enriquecimento de $\mathrm{CO}_{2}$ ao ar livre (FACE) utilizado neste estudo foi uma redução do sistema de injeção sônica de $\mathrm{CO}_{2}$ puro denominado POPFACE (Miglietta et al., 2001), com unidades experimentais circulares, de 2 metros de diâmetro cada. O desenho e a coordenação da montagem deste sistema foram feitos com a colaboração de Franco Miglietta do Instituto de Biometeorologia, Florença, Itália. O sistema FACE possuía cinco componentes principais: Unidade de controle central; anéis de fumigação; sensores de $\mathrm{CO}_{2}$ (IRGAs); tanque de $\mathrm{CO}_{2}$ puro com controle central da pressão do gás no sistema; e computador com acesso remoto a unidade de controle central.

A unidade de controle central, por meio de válvulas solenoides individuais, controlava o volume de $\mathrm{CO}_{2}$ fumigado em cada parcela a fim de manter as concentrações desejadas de $\mathrm{CO}_{2}$ (próximas a $600 \mu \mathrm{mol} \mathrm{mol}{ }^{-1}$ ). Para isso, a unidade utilizava a informação enviada pelos sensores de $\mathrm{CO}_{2}$ de cada parcela. Os anéis de fumigação de $\mathrm{CO}_{2}$, feitos de tubos PVC (1/2"), contém micro furos feitos a laser a uma distância de $5 \mathrm{~cm}$ entre si, em sua face externa (uma vez que o gás deve ser fumigado para fora da parcela). Os anéis ficavam suspensos, na altura do dossel das plantas, delimitando a unidade experimental. O gás era conduzido da unidade de controle central até os anéis através de tubos de alta pressão de polietileno flexível de $0,5 \mathrm{~cm}$ de diâmetro interno. O monitoramento da concentração atmosférica de $\mathrm{CO}_{2}$ era feito individualmente, de modo contínuo, através de analisadores de gases por infravermelho (IRGA, Infrared Gas Analyzer), modelo GTM220 (Vaisala, Finlândia), instalados no centro de cada unidade experimental.

O fornecimento de gás ao sistema foi feito por um tanque de $\mathrm{CO}_{2}$ líquido criogênico ($180^{\circ} \mathrm{C}$ ) com capacidade para armazenar 12 toneladas de produto. A canalização do gás até a 
unidade de controle central era realizada por uma tubulação a uma pressão de 6 bars. Para o controle do sistema era utilizado um computador instalado no interior do container, base de apoio do sistema. O computador conectado à internet por meio de uma fibra ótica permitia o acesso remoto ao microprocessador do FACE por meio de um cabo de rede Ethernet.

O funcionamento do sistema FACE ocorreu, resumidamente, da seguinte forma: A concentração atmosférica de $\mathrm{CO}_{2}$ era amostrada no centro de cada parcela experimental através de seu IRGA. Essa informação era recebida e processada pelo microprocessador da unidade de controle central que, utilizando um algoritmo PID (Proportional Integral Derivative), determinava a voltagem a ser enviada para a válvula solenoide correspondente de cada parcela, para que fosse injetada a quantidade de gás necessária para atingir e manter a concentração de $\mathrm{CO}_{2}$ desejada em cada parcela. Neste sistema, a fumigação com $\mathrm{CO}_{2}$ ocorreu entre às 6:00 e 18:00 horas, no período luminoso. Em função do custo/benefício, os sistemas FACE realizaram a fumigação com $\mathrm{CO}_{2}$ somente durante o período luminoso.

\subsubsection{Descrição do sistema T-FACE}

$\mathrm{O}$ aquecimento das plantas em $2^{\circ} \mathrm{C}$ acima da temperatura ambiente foi realizado por um sistema T-FACE, desenhado e instalado com a colaboração de Bruce Kimball, U. S. Department of Agriculture (USDA), Arizona, USA.

Este sistema continha cinco componentes principais: (1) unidade de controle central, (2) unidade de controle da distribuição de energia nas parcelas experimentais sob aquecimento, (3) aquecedores infravermelhos de cerâmica, (4) termômetros infravermelho, e (5) computador com acesso remoto a unidade de controle central.

A unidade de controle central, localizada no centro da área experimental, era composta por um datalogger CR1000, uma unidade de comunicação NL200 e um multiplexador AM16/32 (Campbell Scientific, EUA). Junto a cada parcela experimental com tratamento de aquecimento foi instalado um painel elétrico para distribuir a energia aos aquecedores instalados em cada parcela. Cada um desses painéis continha um dímero para o ajuste automático da voltagem dos aquecedores (Kalglo, EUA), tomadas independentes para os aquecedores, disjuntores externos e internos e um sistema de ventilação, através de um cooler instalado na região inferior do painel. Cada parcela possuía 6 aquecedores infravermelho de cerâmica de 750 W (modelo FTE-750-240, Salamander Ceramic Infrared Heating Element, Mor Electric, EUA) suspensos a $80 \mathrm{~cm}$ do dossel por meio de uma estrutura horizontal 
triangular formada por 3 barras de alumínio de $6 \mathrm{~m}$, instaladas tangenciando os anéis que delimitaram as parcelas.

Os aquecedores foram instalados em refletores de alumínio (modelo Salamander ALEX, Mor Electric, EUA), que permitem a mobilidade tridimensional de cada refletor e ajuste de sua posição para garantir o aquecimento uniforme das parcelas com tratamento. O monitoramento contínuo da temperatura de cada parcela era realizado por termômetros infravermelho (modelo SI-1H1-L20, Apogee Instruments, EUA), instalados em estruturas de alumínio móvel e orientados no sentido Norte-Sul. Um computador localizado no interior do container de apoio era utilizado para acesso remoto e controle da unidade central do sistema T-FACE. Através de um software de interface LoggerNet (Campbell Scientific, USA) era possível monitorar em tempo real e registrar parâmetros de funcionamento do sistema, como a temperatura do dossel cada parcela e a voltagem enviada aos aquecedores de cerâmica.

Em resumo o sistema T-FACE ocorreu da seguinte maneira: A temperatura do dossel monitorada pelo termômetro infravermelho de uma parcela controle (sem aquecimento) era enviada via cabo ao datalogger da unidade de controle central. A informação era integrada com a velocidade do vento e um programa desenvolvido para este fim que utiliza um algoritmo PID, enviava um sinal ao dímero instalado no painel elétrico específico de cada parcela com aquecimento. Através deste controle automático o dímero regulava em tempo real a voltagem que devia ser enviada simultaneamente aos seis aquecedores de cada parcela a fim de aquecelas a uma temperatura previamente programada. Neste trabalho, todas as parcelas com aquecimento tiveram sua temperatura ajustada em $2^{\circ} \mathrm{C}$ acima da temperatura da parcela controle. O sistema T-FACE funcionava 24 horas por dia, durante todo o período de tratamento. 


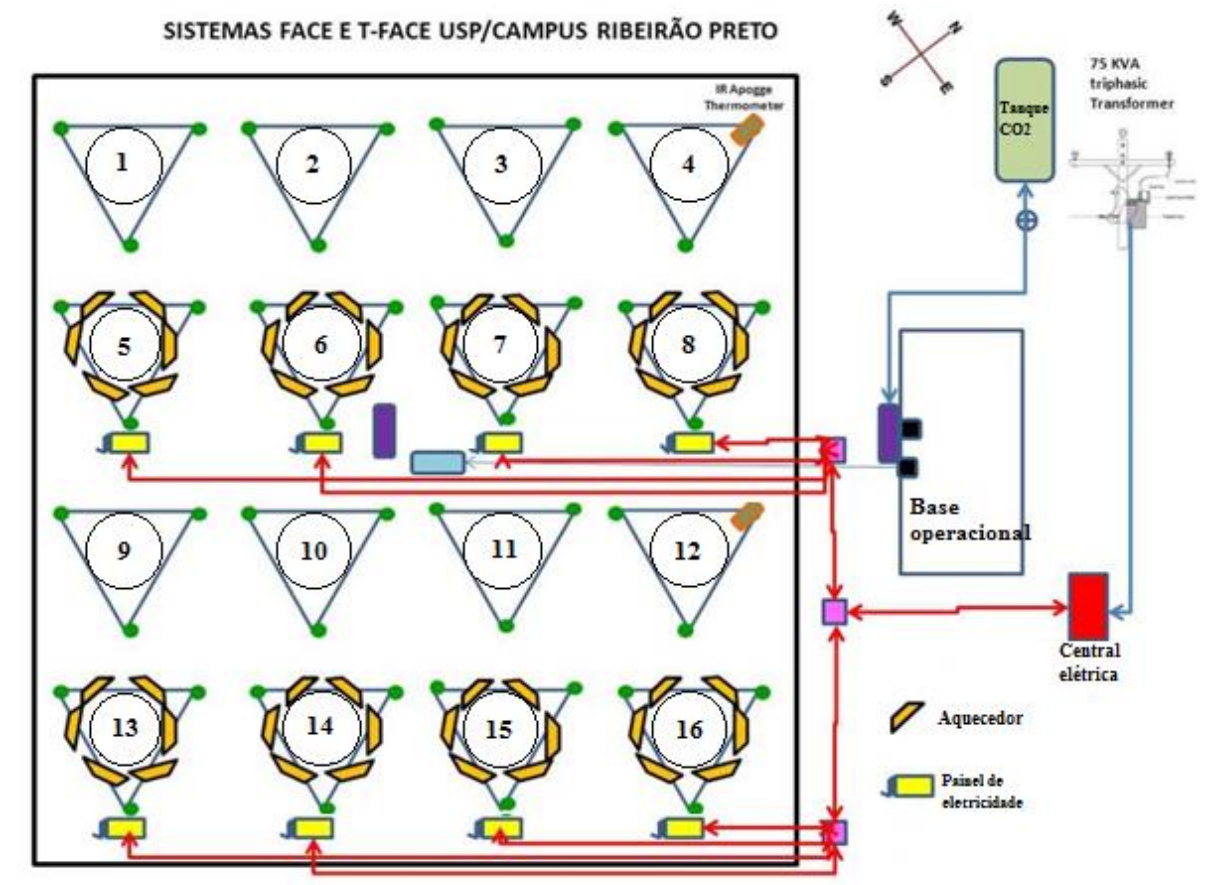

Figura 2: Esquema (vista aérea) da distribuição das parcelas experimentais com sistema FACE e T-FACE instalado na USP/RP. No sistema FACE, as parcelas com elevada concentração de $\mathrm{CO}_{2}$ recebem alimentação de $\mathrm{CO}_{2}$ puro a partir de um tanque criogênico de $\mathrm{CO}_{2}$ de 12 toneladas. No sistema T-FACE, cada parcela aquecida é controlada independentemente por meio de um painel elétrico conectado a sensores de temperatura e ao datalogger central. A energia elétrica para o sistema T-FACE é subministrada pela rede elétrica do campus da USP em Ribeirão Preto a partir de um transformador de $75 \mathrm{KVA}$ instalado especialmente para esse fim.

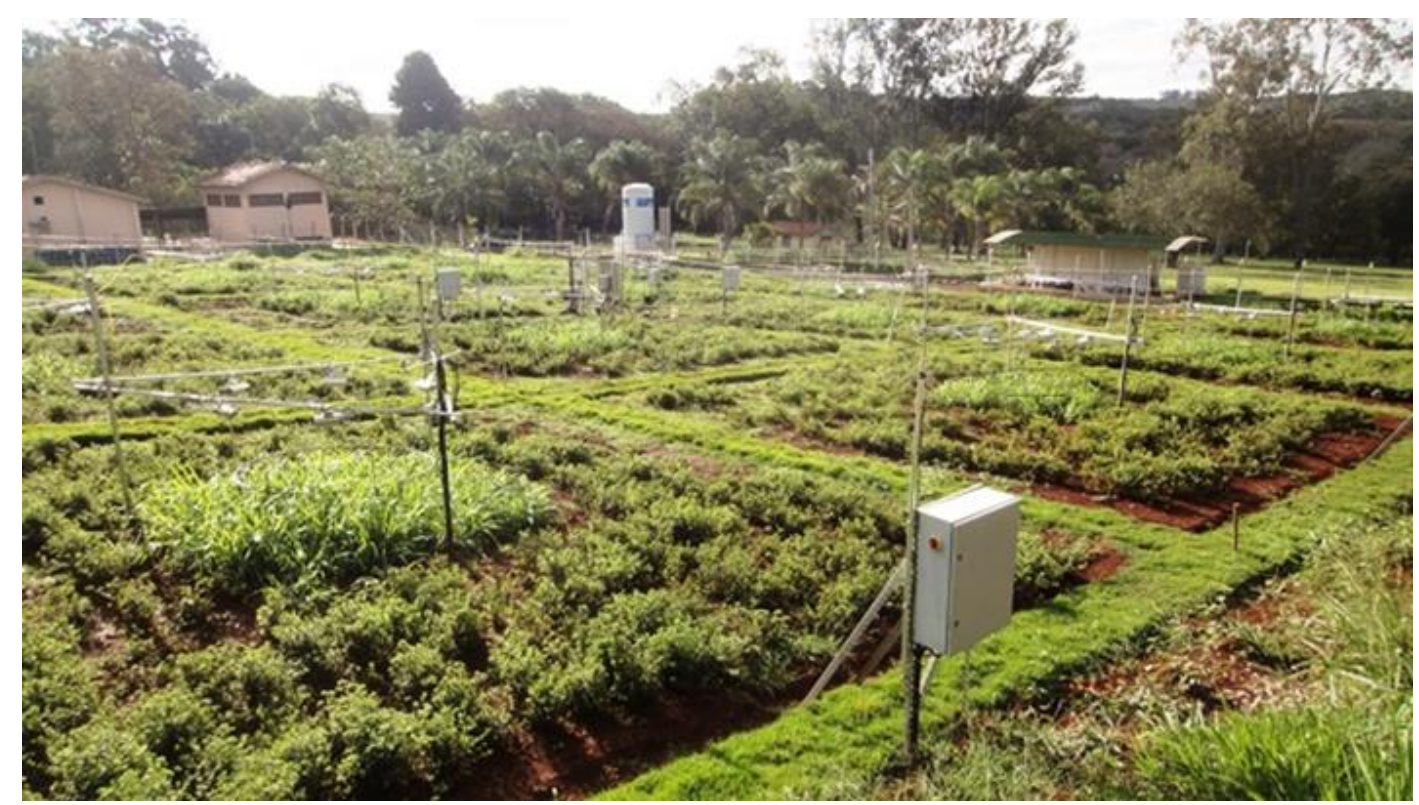

Figura 3: Vista geral da área experimental, com sistemas FACE e T-FACE instalados. 


\subsection{Câmara de Topo Aberto e Fluxo Líquido de $\mathrm{CO}_{2}$ do Ecossistema (NEE)}

As câmaras de topo aberto eram formadas por uma armação cilíndrica de ferro galvanizado com $50 \mathrm{~cm}$ de diâmetro, $82 \mathrm{~cm}$ de altura, composta por 6 hastes verticais de $1 \mathrm{~cm}$ de espessura e 3 anéis horizontais de $1,3 \mathrm{~cm}$ de espessura, totalizando $0,150 \mathrm{~m}^{3}$ de volume. A armação era totalmente revestida, com exceção dos orifícios de entrada e saída de ar, por uma camada de plástico flexível de PVC transparente Cristal de 0,20 mm de espessura (Plásticos Alko, Ltda., Brasil). A metade inferior da câmara era composta por uma camada dupla do mesmo plástico, formando um bolsão de ar em formato anelar, com furos de $0,8 \mathrm{~cm}$ de diâmetro espalhados de maneira uniforme pela camada interna da câmara.

Tanto no orifício de entrada quanto no de saída de ar das câmaras era encaixado um tubo de PVC (Tigre, SC, Brasil) de $10 \mathrm{~cm}$ de diâmetro com filtros de malha plástica na entrada, para evitar a entrada de insetos e grandes partículas. Cada tubo possuía um ventilador de ducto do tipo exaustor in line de $100 \mathrm{~mm}, 120 \mathrm{~V}, 13 \mathrm{~W}$ modelo Mega10 (SICFLUX, Brasil) que garantia o fluxo de ar na câmara. No momento da coleta de dados era acoplado em cada tubo um anemômetro, modelo 9871 Anemometer Printer (AZ Instrument Corp) para medição e monitoramento do fluxo do ar, bem como da temperatura e umidade relativa do ar. Cada tubo de PVC continha também um sensor de $\mathrm{CO}_{2}$ do tipo IRGA modelo PR01-0037 (Tekna Impanti, Firenze, Itália). As leituras das $\left[\mathrm{CO}_{2}\right]$ eram adquiridas em tempo real utilizando o programa HyperTerminal (Hilgraeve Inc.) através de um computador conectado aos IRGAs (Figura 4). 


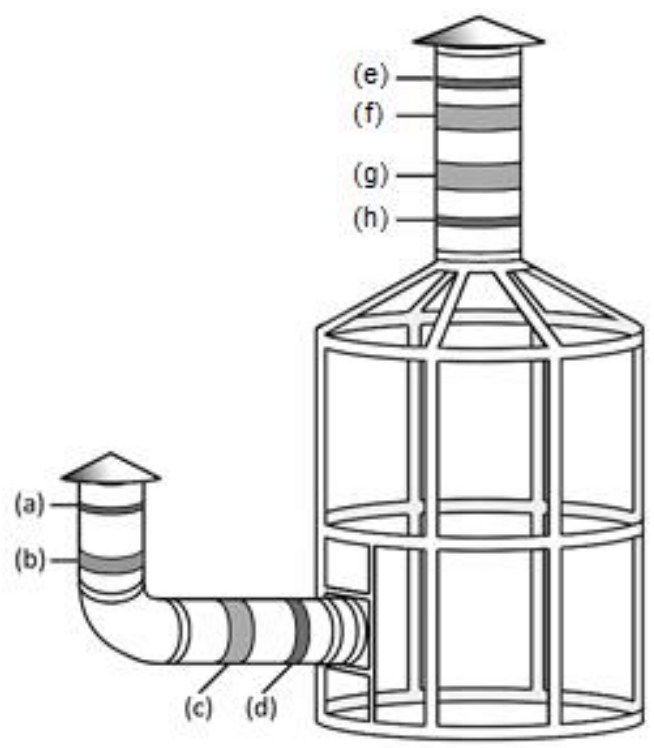

Figura 4: Ilustração esquemática da câmara de topo aberto (OTC), mostrando os componentes utilizados. No ducto de entrada de ar: a) filtro; b) anemômetro; c) ventoinha; d) IRGA. No ducto de saída de ar: e) filtro; f) ventoinha; g) IRGA; h) anemômetro.

As medições de NEE foram feitas através das OTCs, operadas como um sistema aberto de medições de trocas gasosas (Drake et al., 1996; Olivo et al., 2012; Erikson et al., 2013. O sistema de OTC estima diretamente a NEE, ou seja, o fluxo líquido entre o ecossistema e a atmosfera por unidade de área $\left(\mu \mathrm{mol} \mathrm{CO}_{2} \mathrm{~m}^{-2} \mathrm{~s}^{-1}\right)$. Apesar de tanto os dados de NEE diurno quanto noturno serem representados por valores positivos, durante o dia ocorre um fluxo de $\mathrm{CO}_{2}$ da atmosfera para o ecossistema (fixação), enquanto que de noite o fluxo é inverso (liberação).

Para as medições de NEE, a OTC era acoplada a uma base de formato circular fixa no solo de cada parcela contendo material vegetal. $\mathrm{O}$ ar do entorno era bombeado para dentro da câmara usando uma câmara de mistura de ar, formando um fluxo de entrada e saída de ar, que permitia a medição do NEE como a diferença entre as concentrações de $\mathrm{CO}_{2}$ nos pontos de entrada $\left(\mathrm{C}_{\text {in }}\right)$ e saída $\left(\mathrm{C}_{\text {out }}\right)$ de ar multiplicadas pela taxa de fluxo do ar. As concentrações de $\mathrm{CO}_{2}$ de entrada e saída eram medidas com IRGAs independentes. Após acopladas, esperava-se cerca de 60 segundos para que o ar interno se homogeneizasse e então a leitura de $C_{\text {in }}$ e $C_{\text {out }}$ era feita a cada segundo durante 5 minutos, o valor médio era utilizado para o cálculo do NEE. O curto período de amostragem evitou que a temperatura e a umidade do ar dentro da câmara aumentassem durante as análises, diminuindo o efeito de câmara. Os valores eram obtidos em $\mu \mathrm{mol} \mathrm{mol}{ }^{-1} \mathrm{de} \mathrm{CO}_{2}$ e então o NEE era calculado através da formula: $\mathrm{NEE}=\phi_{\times} \Delta \mathrm{CO}_{2} / \mathrm{S}$. Onde 
$\phi$ é o fluxo de ar do sistema, $\Delta \mathrm{CO}_{2}$ é a média da diferença entre os valores de $\mathrm{CO}_{2}$ de entrada e saída obtidos pelo IRGA da câmara e $\mathrm{S}$ é a área da câmara.

\subsection{Biomassa}

A biomassa foi estimada através da coleta destrutiva de todo material vegetal acima do solo que se encontrava dentro da base fixa ao solo utilizada pela OTC nas medições de NEE. As coletas foram realizadas no último dia de experimento, as amostras foram separadas em folhas e caules e secas em estufa a temperatura de $70^{\circ} \mathrm{C}$ por 48 horas. No experimento com $S$. capitata foram também coletadas as inflorescências e contabilizadas junto às folhas.

\subsection{Respiração do Solo}

A taxa de respiração do solo, em $\mu \mathrm{mol} \mathrm{mol}^{-1}$ de $\mathrm{CO}_{2}$, foi medida utilizando um IRGA portátil (LiCor 8100-A, Lincoln, Nebraska, USA). Cada parcela possuía dois anéis de tubos PVC de 10 polegadas de diâmetro permanentemente inserido no solo $10 \mathrm{~cm}$ abaixo e $5 \mathrm{~cm}$ acima do solo e sem nenhum tipo de vegetação em seu interior. Cada medição durou cerca de 2 minutos, entre a fixação do aparelho no anel e a aquisição dos dados, e foram realizadas na última semana de experimento.

\subsection{Fluxo de metano}

O fluxo de metano $\left(\mathrm{CH}_{4}\right)$ foi estimado através de medições por câmara estática e cromatografia gasosa. As amostras de ar foram obtidas com câmaras estáticas circulares de área $0,052 \mathrm{~m}^{2}$ e volume de $6 \mathrm{~L}$. A base de cada câmara de amostragem de ar, com isolamento por lamina d'água na borda superior foi mantida inserida $5 \mathrm{~cm}$ no solo. Esta base foi o suporte para o topo conectado no momento das coletas. O topo de cada câmara era dotado de uma válvula manual para acoplamento de seringas de coleta de ar. Antes de cada coleta, o ar foi homogeneizado dentro da câmara. Cada parcela possuía uma câmara estática de coleta de ar. O ar de dentro da câmara foi coletado com seringas de polipropileno de $20 \mathrm{ml}$ aos $0,5,10$ e 30 minutos após o fechamento das câmaras. AS coletas foram realizadas na última semana de experimento. As amostras de ar foram armazenadas em vials a vácuo e analisadas por cromatografia gasosa (SRI-8610C, Germany). As análises de metano em cromatografia gasosa 
a partir de amostras de gás coletado no campo foram realizadas no Centro de Energia Nuclear na Agricultura da Universidade de São Paulo (CENA-USP) com a colaboração da Prof. Dr. Tsai Sui Mui e sua equipe.

\subsection{Análise Estatística}

Todas as análises estatísticas foram feitas utilizando o programa Graphpad Prism, aplicando testes two-way ANOVA com nível de significância $\mathrm{p} \leq 0,05$. 


\section{EXPERIMENTO I}

\subsection{Delineamento Experimental}

O experimento ocorreu de 24/04/2015 a 29/06/2015, utilizando Stylosanthes capitata Vogel em tratamentos de elevada $\left[\mathrm{CO}_{2}\right]$ e temperatura. Totalizando 66 dias de tratamento.

S. capitata é uma leguminosa de via fotossintética $\mathrm{C}_{3}$, nativa do Brasil. Possui capacidade de fixação de nitrogênio e grande concentração de nitrogênio em seus tecidos, sendo utilizada em consórcio com as gramíneas forrageiras, principalmente em áreas de cerrado. Além disso, possui altas taxas de produção de biomassa e sementes (SANTOS et al., 2009).

Após o preparo do solo, os indivíduos foram igualmente semeados a lanço em todas as parcelas e cultivados em condições ambiente, com rega por cerca de 75 dias. Após este período, foi realizado um corte de uniformização a $40 \mathrm{~cm}$ do solo e dado início aos tratamentos.

O delineamento experimental foi organizado em quatro blocos. Cada bloco possuía quatro unidades experimentais, chamadas de parcelas, contendo combinações dos tratamentos (Figura 5):

- $\mathrm{aC}-\left[\mathrm{CO}_{2}\right]$ ambiente: concentração ambiente de $\mathrm{CO}_{2}$, aproximadamente 400 ppm;

○ eC - [ $\left.\mathrm{CO}_{2}\right]$ elevada: 50\% acima da concentração ambiente, aproximadamente 600 ppm;

- aT - Temperatura ambiente: temperatura atmosférica do ambiente;

○ eT - Temperatura elevada: $2{ }^{\circ} \mathrm{C}$ acima da temperatura ambiente

As avaliações foram efetuadas de 21 a 66 dias após o início dos tratamentos, tempo no qual ocorre a rebrota e formação de nova biomassa. 
SISTEMAS FACE E T-FACE USP/CAMPUS RIBEIRÃO PRETO
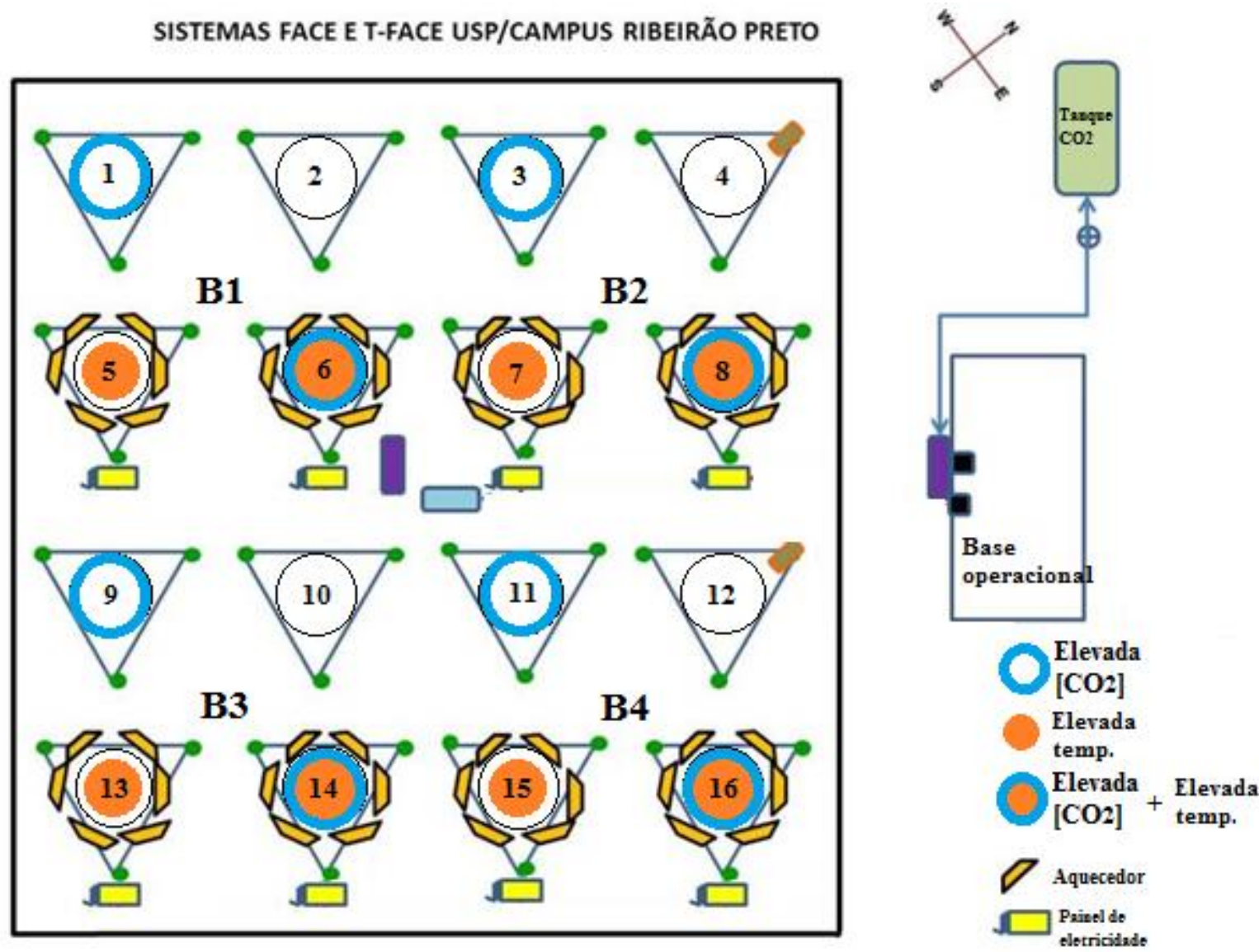

Figura 5: Esquema ilustrativo do campo experimental, evidenciando as 16 parcelas com tratamentos de elevada $\left[\mathrm{CO}_{2}\right]$, elevada temperatura e elevada $\left[\mathrm{CO}_{2}\right]+$ temperatura. As parcelas foram divididas em 4 blocos contendo as diferentes combinações de tratamento. 


\subsection{Resultados}

O experimento com S. capitata teve início no dia 24 de abril de 2015 e término no dia 29 de junho de 2015, com duração total de 66 dias e ocorrendo majoritariamente durante o Outono. Ao longo do experimento foi observada uma gradativa redução temperatura média do ar, sendo que as maiores temperaturas do experimento foram registradas na primeira semana de tratamentos (temperaturas média, máxima e mínima de 23,5, 32,7 e 12,3ํㅡ.

A umidade relativa do ar mínima foi reduzida de $41,1 \%$ em abril, para $36,1 \%$ em maio e $33,5 \%$ em junho. Durante o período experimental o acumulado de chuvas foi de $120 \mathrm{~mm}$, sendo que $93,3 \mathrm{~mm}$ de chuva forma registrados nos primeiros 25 dias de experimento. Nos últimos 26 dias, período no qual a maior parte dos dados foram coletados, foram registrados apenas 6,6 mm de chuva (Figura 6).

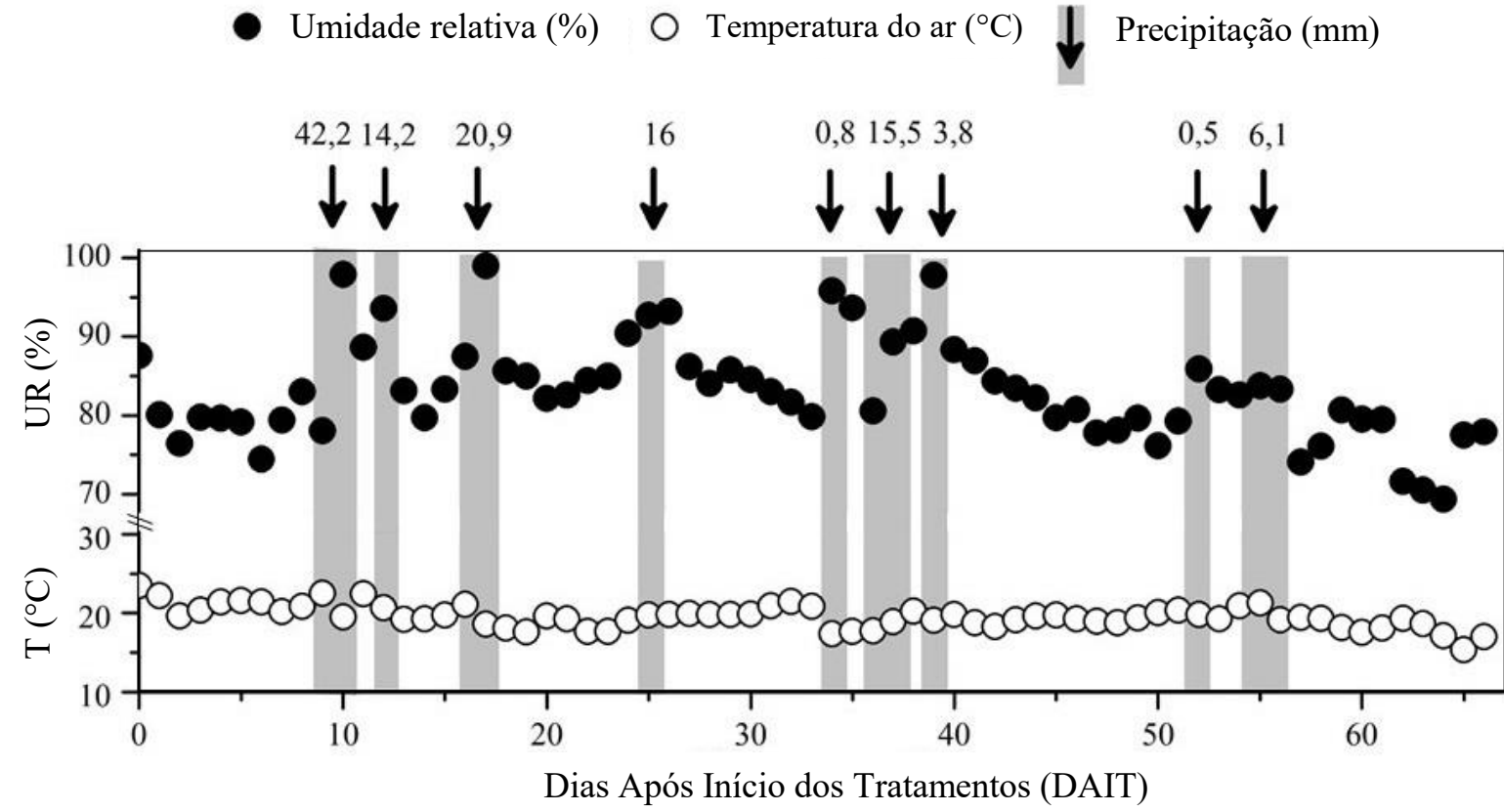

Figura 6: Médias diárias de temperatura do ar $\left({ }^{\circ} \mathrm{C}\right)$, umidade relativa do ar $(\%)$ e precipitação (mm) registradas durante o período experimental com $S$. capitata em sistema T-FACE. As setas e bandas cinzas mostram as precipitações ocorridas durante o experimento e dias de chuvas consecutivos foram condensados. $\mathrm{O}$ experimento ocorreu de 24/04/2015 a 29/06/2015, totalizando 66 dias de tratamento.

O tratamento com elevada $\left[\mathrm{CO}_{2}\right]$ não teve efeito sobre a biomassa de folhas $(\mathrm{p}=0,3945)$. Já o tratamento com elevada temperatura alterou negativamente a biomassa de folhas $(\mathrm{p}=$ 0,0351). No entanto, não houve alteração da biomassa de folhas no tratamento conjunto de 
elevada $\left[\mathrm{CO}_{2}\right]$ e temperatura $(\mathrm{p}=0,2004)$ (Figura $\left.7 \mathrm{~A}\right)$. A biomassa de caules foi alterada positivamente somente no tratamento com elevada $\left[\mathrm{CO}_{2}\right](\mathrm{p}=0,0115)$, sem efeitos na biomassa pelos tratamentos de elevada temperatura $(\mathrm{p}=0,0593)$ e tratamento combinado $(\mathrm{p}=0,1987)$ (Figura 7B). Mesmo com o aumento da biomassa de caules no tratamento combinado, não foi observada alterações da biomassa total pelo tratamento combinado ( $\mathrm{p}=0,0577)$, nem pelo tratamento de elevada $\left[\mathrm{CO}_{2}\right](\mathrm{p}=0,1518)$, porém, o tratamento de elevada temperatura diminuiu a biomassa total $(\mathrm{p}=0,0129)$, pela redução da biomassa de folhas (Figura 7C).

O fluxo líquido de carbono do ecossistema (NEE) na medição pontual diurna foi maior no grupo com elevada $\left[\mathrm{CO}_{2}\right](\mathrm{p}<0,0001)$, porém, foi inalterado no tratamento de elevada temperatura ( $p=0,8998)$, assim como no tratamento combinado $(p=0,9785)$ (Figura 8A). Já o NEE noturno não foi alterado pela elevada $\left[\mathrm{CO}_{2}\right](\mathrm{p}=0,8236)$, temperatura $(\mathrm{p}=0,1327)$, nem pelo tratamento combinado $(\mathrm{p}=0,4647)$ (Figura 8B). 

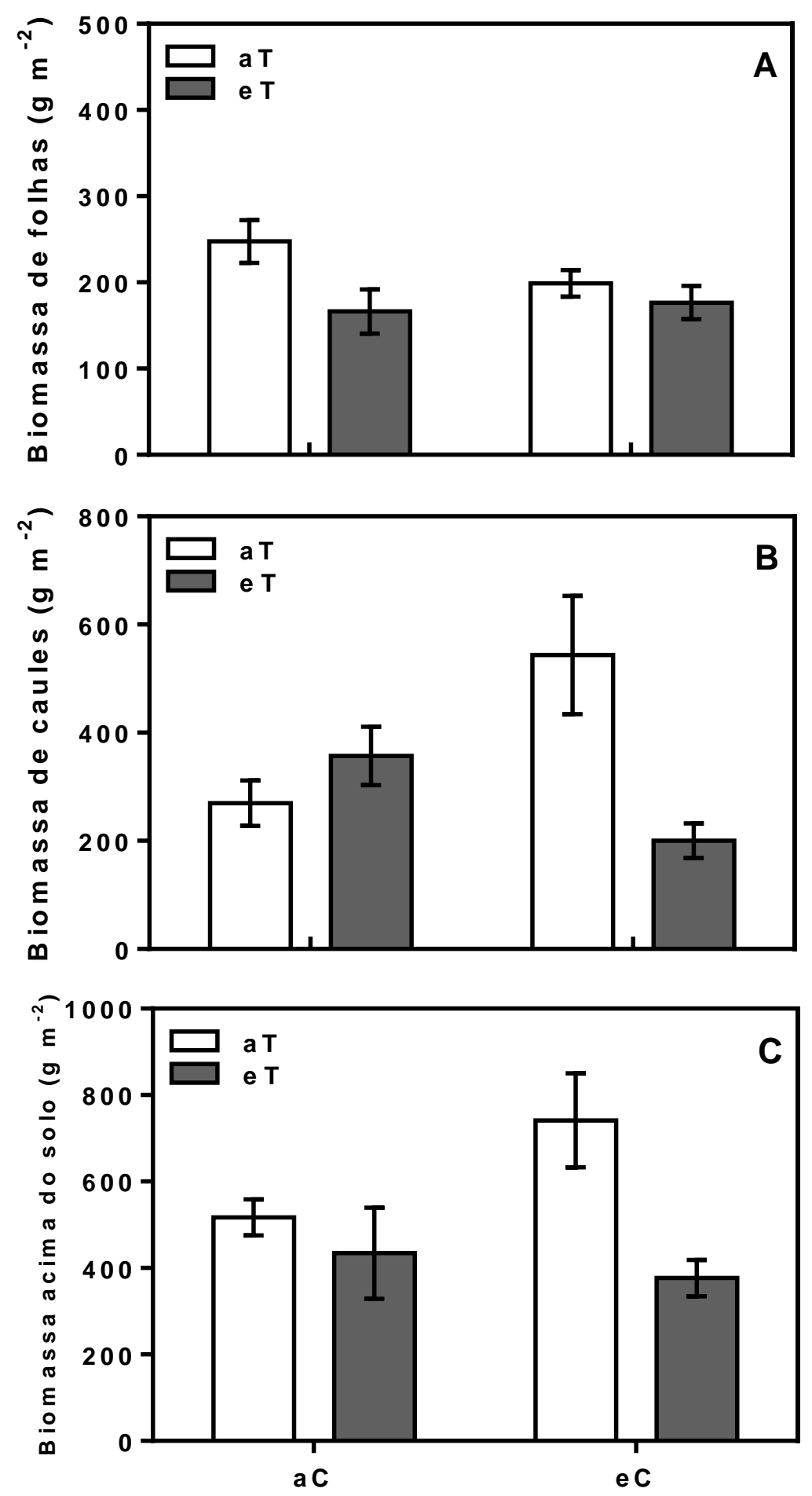

Figura 7: (A) Biomassa de folhas, (B) biomassa de caules e (C) biomassa total acima do solo em $\mathrm{g} \mathrm{m}^{-2}$ de $S$. capita ao final do experimento sob tratamentos combinados de $\left[\mathrm{CO}_{2}\right]$ ambiente $(\mathrm{aC}),\left[\mathrm{CO}_{2}\right]$ elevada (eC), temperatura ambiente (aT), e temperatura elevada (eT) em sistema T-FACE. 

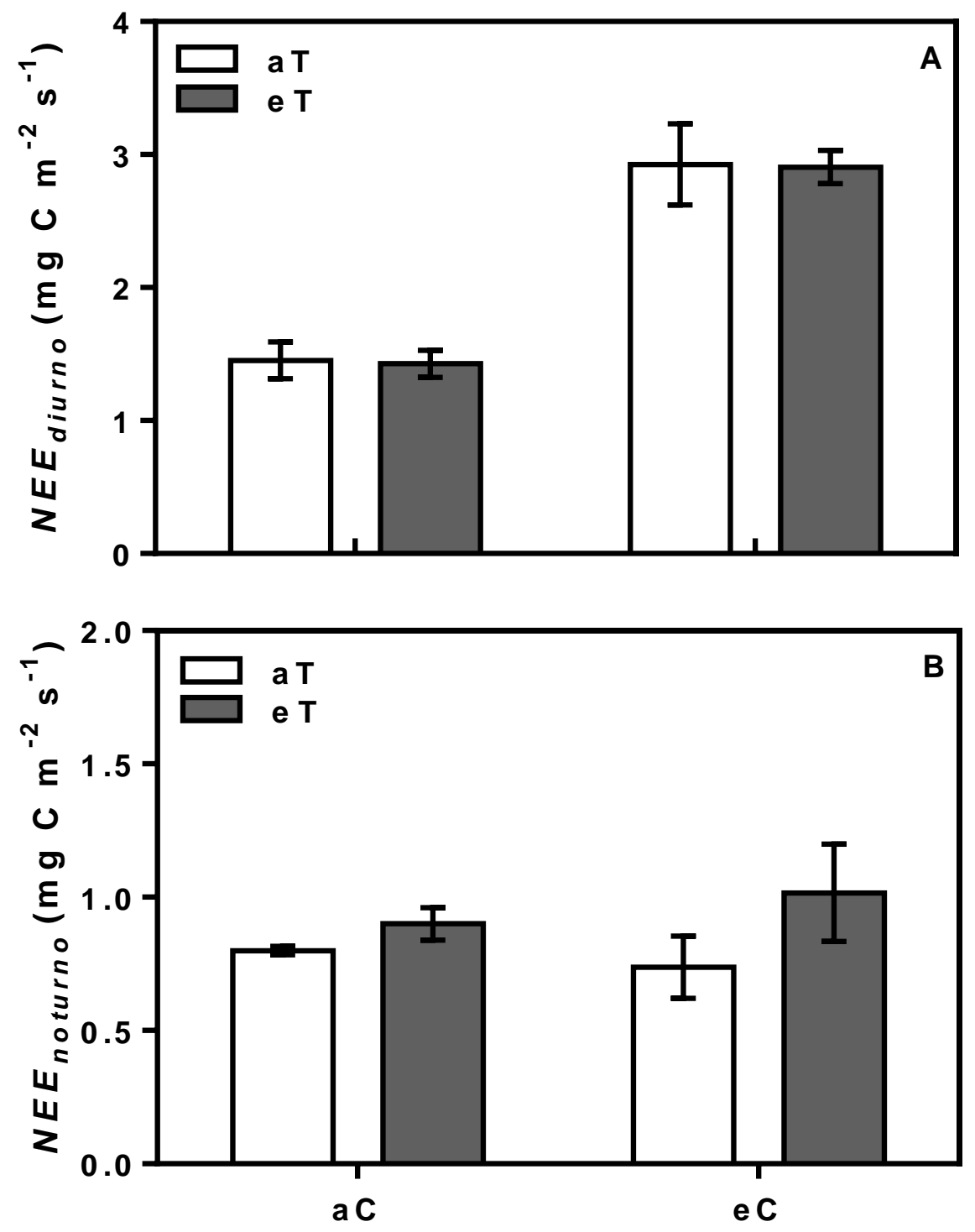

Figura 8: (A) Fluxo líquido de carbono do ecossistema durante período diurno, medido às 12:00 horas, e (B) período noturno, medido às 21:00 horas, em $\mathrm{mg}$ de carbono $\mathrm{m}^{-2} \mathrm{~s}^{-1}$, utilizando câmara de topo aberto em $S$. capitata sob condições de ambiente $\left[\mathrm{CO}_{2}\right](\mathrm{aC})$, elevada $\left[\mathrm{CO}_{2}\right](\mathrm{eC})$, temperatura ambiente $(\mathrm{aT})$ e temperatura elevada $(\mathrm{eT})$ em sistema T-FACE. Média \pm erro padrão.

Nas medições diurnas de respiração do solo não houveram alterações pelos tratamentos de elevada $\left[\mathrm{CO}_{2}\right](\mathrm{p}=0,1869)$, temperatura $(\mathrm{p}=0,0576)$ e tratamento combinado $(\mathrm{p}=0,7325)$ (Figura 9A). No entanto, a respiração do solo noturno aumentou nos tratamentos de elevada $\left[\mathrm{CO}_{2}\right](\mathrm{p}=0,0075)$, temperatura $(\mathrm{p}=0,0203)$ e tratamento combinado $(\mathrm{p}=0,0028)($ Figura 9B) 

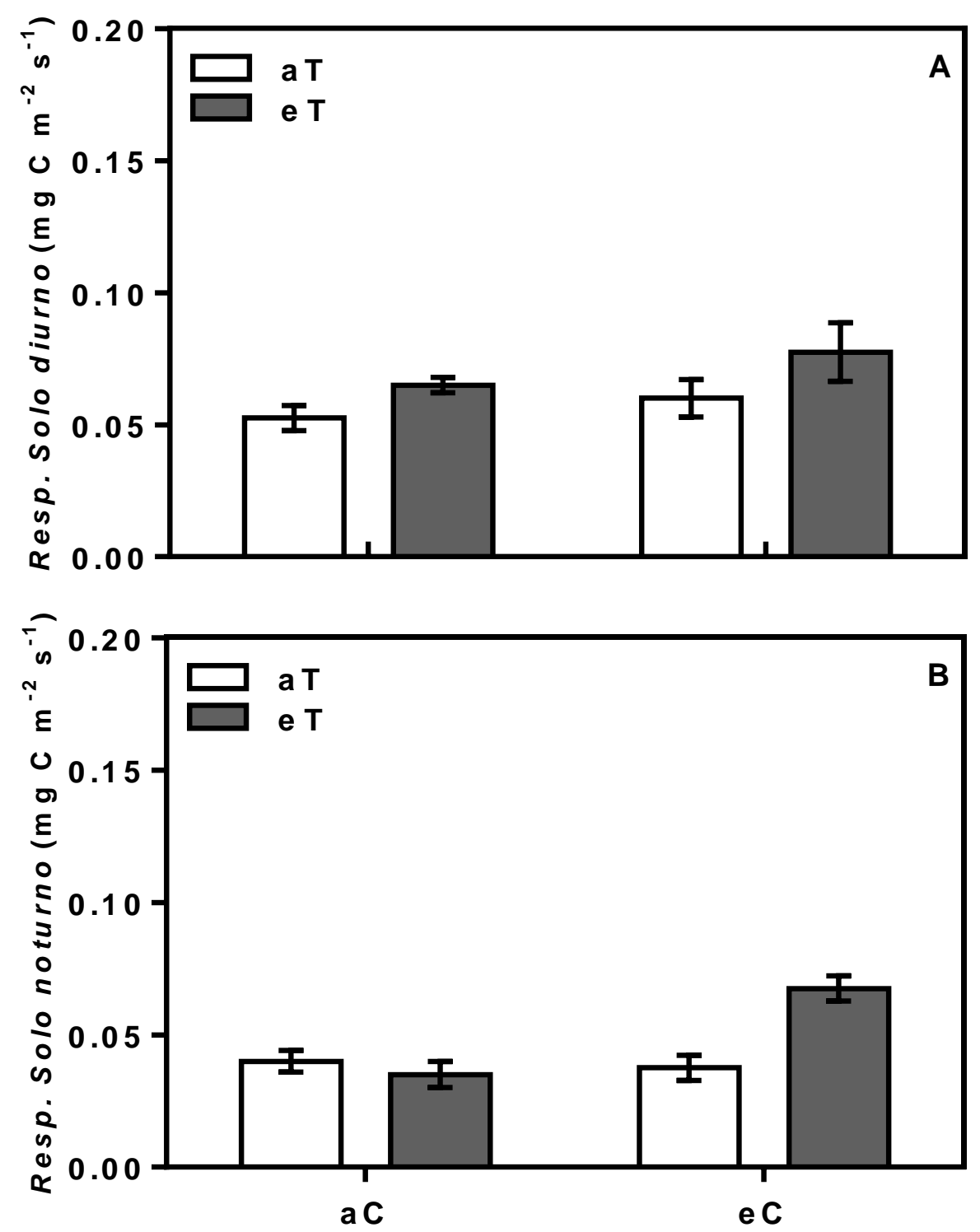

Figura 9: (A) Respiração do solo durante o período diurno (12:00 horas) e (B) respiração do solo durante o período noturno (21:00 horas) em $\mathrm{mg}$ de carbono $\mathrm{m}^{-2} \mathrm{~s}^{-1}$. Medições realizadas em solo sem plantas, em condições de ambiente $\left[\mathrm{CO}_{2}\right](\mathrm{aC})$, elevada $\left[\mathrm{CO}_{2}\right](\mathrm{eC})$, temperatura ambiente (aT) e temperatura elevada (eT) em sistema TFACE. Média \pm erro padrão. 
Os valores negativos de metano mostram que o solo sob cultivo de $S$. capitata está atuando como sumidouro de carbono derivado do $\mathrm{CH}_{4}$. No entanto, não foram observadas mudanças nas taxas de fixação de metano nos tratamentos de elevada $\left[\mathrm{CO}_{2}\right](\mathrm{p}=0,1578)$, temperatura $(p=0,2030)$ e tratamento combinado $(p=0,3191)$ (Figura 10).

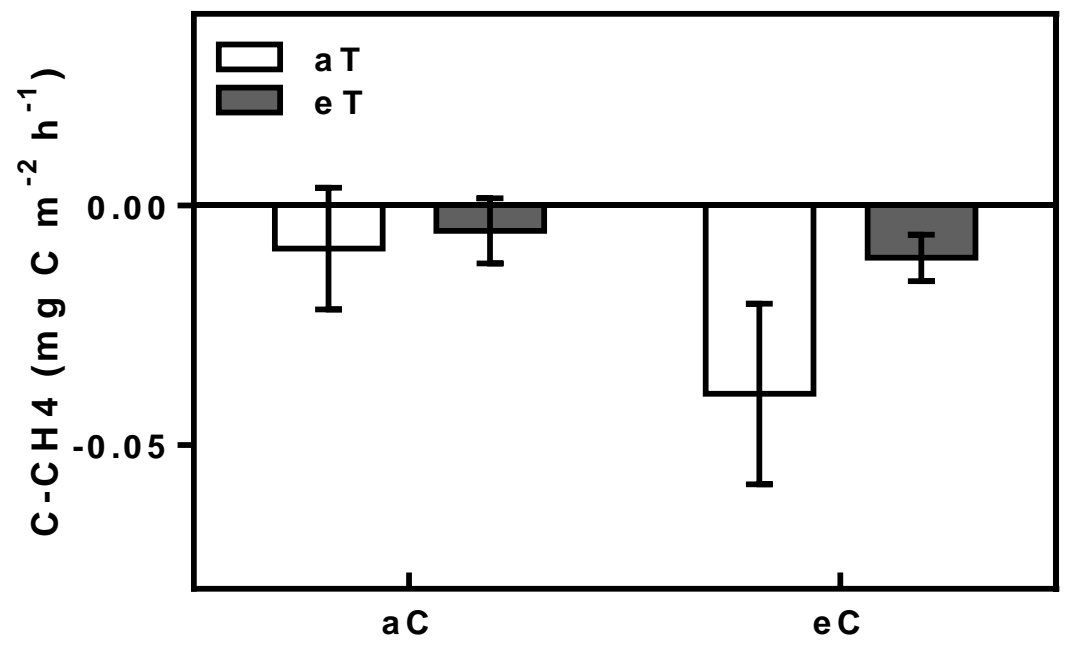

Figura 10: Fluxo de metano $\left(\mathrm{CH}_{4}\right)$ do solo em $\mathrm{mg}$ de carbono $\mathrm{m}^{-2} \mathrm{~h}^{-1}$ sob cultivo de $S$. capitata em condições de ambiente $\left[\mathrm{CO}_{2}\right](\mathrm{aC})$, elevada $\left[\mathrm{CO}_{2}\right](\mathrm{eC})$, temperatura ambiente (aT) e temperatura elevada (eT) em sistema TFACE. Média \pm erro padrão. 


\subsection{Discussão}

Um dos efeitos mais observados em plantas quando sujeitas a elevadas $\left[\mathrm{CO}_{2}\right]$ é o aumento na biomassa, pela maior assimilação de carbono e eficiência no uso do carbono (CUE) (CARRILLO et al., 2011; IRVING, 2015; MARTINEZ et al., 2014). Neste trabalho, o único aumento na biomassa pelo incremento de $\mathrm{CO}_{2}$ atmosférico foi observado na biomassa de caules, pelo tratamento de elevada $\left[\mathrm{CO}_{2}\right]$. Por outro lado, a biomassa de folhas e biomassa total sofreu diminuição no tratamento de elevada temperatura.

É importante frisar que no início dos tratamentos as plantas estavam em fase reprodutiva, já em estágio de floração, portanto, é possível que o aumento apenas na biomassa de caule no tratamento $\mathrm{eC}$ tenha sido devido ao maior aporte de carbono, em maior disponibilidade pela elevada $\left[\mathrm{CO}_{2}\right]$, para órgãos estruturais, como caules e raízes, em preparo para o próximo estágio vegetativo. Provavelmente devido a estarem em um estágio fenológico mais avançado, as plantas sob elevada temperatura já se encontravam em final de floração no momento de coleta da biomassa, ao final do experimento, portanto, já haviam perdido parte de sua biomassa de folhas e inflorescências no processo de senescência (BHATT et al., 2010; CARVALHO et al., 2006).

Em um estudo utilizando a gramínea $\mathrm{C}_{3}$ Chenopodium album cultivada em elevada temperatura e $\left[\mathrm{CO}_{2}\right]$, Lee (2011) observou efeitos de fenologia avançada nas plantas sob elevada temperatura, por apresentarem surgimento das mudas cerca de $30 \%$ mais rápido do que o controle e início da floração cerca de 25\% mais rápido (LEE, 2011). Isso pode significar que, em um cenário futuro de maior concentração de $\mathrm{CO}_{2}$ atmosférico e maior temperatura, forrageiras $C_{3}$ de pastagem tenham sua fenologia acelerada, proporcionando um tempo mais curto entre crescimento e utilização pelo gado e assim exigir mudanças no manejo do pasto, por modificar a demanda de água e nutrientes pelas plantas (HALL et al., 1998).

As coletas noturnas de NEE não apresentaram diferenças para ambos os tratamentos, ou seja, a elevação em $2^{\circ} \mathrm{C}$ na temperatura não foi o suficiente para causar alterações fisiológicas, como a respiração autotrófica e heterotrófica, ligadas ao fluxo do carbono durante o período noturno. Além disso, durante a noite, não era realizada o enriquecimento atmosférico de $\mathrm{CO}_{2}$, por, entre outros motivos, não ocorrer fotossíntese nesse período. Dessa forma, a ausência de um impacto da elevada $\left[\mathrm{CO}_{2}\right]$ no fluxo de carbono do ecossistema durante período noturno era esperado. 
Os dados de NEE diurno mostraram um aumento na fixação do carbono somente no tratamento com elevada $\left[\mathrm{CO}_{2}\right]$. Uma vez que se observa maior fixação de $\mathrm{CO}_{2}$ nesse grupo, seria esperado também uma maior biomassa, o que não foi observado. No entanto, vale ressaltar que as medições de NEE são valores pontuais medidos em períodos de grande eficiência fotossintética, assim, a extrapolação para valores absolutos de biomassa estaria superestimada. Entender a dinâmica de alocação de biomassa pelas plantas é uma tarefa complexa, uma vez que se faz necessário quantificar todos os processos relacionados com a mobilização e utilização do carbono orgânico, como a síntese de compostos carbônicos, a respiração celular, a produção de exsudatos pelas raízes e metabólitos voláteis (LAMBERS; ATKIN; MILLENAAR, 1996; POORTER et al., 2011).

Podemos inferir que a maior taxa de fixação de carbono em eC está relacionada a uma maior taxa fotossintética, propiciada pela maior quantidade de $\mathrm{CO}_{2}$ disponível para a enzima Rubisco, esse sendo um dos maiores limitantes da fotossíntese em espécies $\mathrm{C}_{3}$ (TAIZ; ZEIGER, 2006). Já a maior conversão em biomassa desse carbono fixado foi apenas observada nos caules dos tratamentos de eC+eT, como já discutidos anteriormente, dentre outros motivos, possivelmente por estarem num estágio fenológico avançado, propício ao crescimento vegetativo, uma vez que nesse estágio há maior fixação em biomassa do carbono extra pelos drenos (BHATT et al., 2010).

A maior fixação de carbono pelas pastagens em um cenário futuro de mudanças climáticas pode conferir a estes ecossistemas maior potencial como dreno de carbono atmosférico e como agentes de mitigação das mudanças climáticas por serem sumidouros de $\mathrm{CO}_{2}$, importante gás causador do aquecimento global. No entanto, para a agropecuária, maior taxa fotossintética com maior alocação de biomassa para o caule pode significar maiores custos com insumos, como nitrogênio, e menor rendimento da pastagem, uma vez que o gado se alimenta principalmente das folhas das plantas (CAMPBELL; STAFFORD SMITH, 2000; HALL et al., 1998).

Outro fator intimamente ligado à dinâmica do carbono no ecossistema é a respiração do solo, proveniente tanto da respiração autotrófica de raízes quanto da respiração heterotrófica, majoritariamente pela atividade da microbiota do solo e da decomposição da matéria orgânica. O aumento na temperatura do solo pode impactar o metabolismo e a atividade enzimática dos seres heterotróficos a ponto de modificar suas dinâmicas com o $\mathrm{CO}_{2}$. Além disso, a elevada $\left[\mathrm{CO}_{2}\right]$ pode alterar a respiração do solo de maneira indireta, por causar mudanças estruturais e 
fisiológicas nas raízes, alterando a respiração autotrófica do solo (CARRILLO et al., 2011; MAIA et al., 2010).

A interação do aumento da $\left[\mathrm{CO}_{2}\right]$ e temperatura com os processos que ocorrem abaixo do solo relacionados ao carbono, principalmente a respiração de raízes e a decomposição da matéria orgânica do solo, ainda são pouco compreendidos. $\mathrm{O}$ entendimento desses processos ajudará a determinar o potencial dos solos de pastagem como estoques de carbono e seu papel como mitigador ou agravador do aquecimento global (PENDALL et al., 2001).

Um estudo anterior, do mesmo grupo de pesquisa deste tralho e na mesma área experimental, utilizando $S$. capitata e $P$. maximum, mostrou que o aquecimento em $2^{\circ} \mathrm{C}$ proveniente do sistema T-FACE elevou a temperatura do solo em $1{ }^{\circ} \mathrm{C}$. Neste mesmo experimento foi observado um aumento na respiração do solo com elevada temperatura às 18 horas em relação ao seu controle, mas nenhuma diferença foi encontrada nas mesmas análises às 12 horas.

Nos experimentos realizados neste trabalho, as medições de respiração do solo foram também realizadas às 12 e 18 horas e, assim como no estudo anterior, nenhuma diferença foi encontrada na respiração diurna e houve um aumento na respiração do solo noturno, pelos tratamentos eC, eT e eCeT.

Dois motivos podem estar relacionados com esses resultados. Um deles, no que diz respeito a respiração heterotrófica, pode ser inferido que havia maior atividade heterotrófica no período noturno e não no diurno quando sob elevada temperatura, pois a temperatura ideal para os processos microbianos era mantida por mais tempo no tratamento com elevada temperatura (GOMEZ-CASANOVAS et al., 2012). Dessa forma, apesar dessa elevação não ter feito diferença durante o dia, onde a temperatura já era ideal, durante a noite esse acréscimo na temperatura possivelmente foi capaz de aumentar a atividade microbiana e, consequentemente, a respiração do solo.

Um outro motivo seria em relação ao aumento da respiração do solo pela respiração autotrófica abaixo do solo, uma vez que, com uma maior fixação de carbono pelas plantas sob eC durante o dia, esse pool extra de carbono pode estar sendo particionado para as raízes e, por sua vez, uma maior quantidade de raízes no solo levaria a uma maior respiração do solo.

Além disso, é discutido em um estudo com gramíneas nativas $\mathrm{C}_{3}$ e $\mathrm{C}_{4}$ que a atividade fotossintética das plantas pode influenciar também na atividade heterotrófica do solo, efeito conhecido como priming. Esse efeito ocorre pela produção de exsudatos e quebra dos agregados do solo pelas raízes, que estimulam a atividade de decomposição pela microbiota do solo 
(GOMEZ-CASANOVAS et al., 2012). O efeito acentuado do priming como consequência de maior atividade radicular resultante da elevada $\left[\mathrm{CO}_{2}\right]$ pode inclusive ser um fator mais impactante na respiração do solo do que o aumento da temperatura do solo (CHAPIN et al., 2009).

Nesse trabalho, a biomassa de raízes não foi mensurada, porém, outros trabalhos do projeto geral no qual este trabalho se insere avaliaram a biomassa de raízes dos experimentos. Esses dados serão cruzados para investigar possíveis relações da elevada $\left[\mathrm{CO}_{2}\right]$ e temperatura com a fixação de carbono pelo ecossistema, biomassa abaixo do solo e taxa fotossintética em futuras publicações.

Além do $\mathrm{CO}_{2}$, outro importante gás ligado a dinâmica do carbono nos ecossistemas e de influência nas mudanças climáticas é o metano. O balanço de liberação e absorção de metano ocorre por microrganismos metanotróficos e metanogênicos no solo, e sua concentração também deve ser levada em conta nas modelagens de fixação de carbono pelos ecossistemas (TOPP; PATTEY, 1997).

No experimento com $S$. capitata houve um predomínio de atividades metanotróficas. Isso se deve ao fato de que foi observado valores negativos de $\mathrm{CH}_{4}$ durante as medições de metano do solo, devido ao consumo de metano por microrganismos metanotróficos. Assim, como observado na maioria dos sistemas agrícolas modernos (SMITH et al., 2008a), o ecossistema de pastagem em estudo serviu como dreno de carbono proveniente do metano.

Ainda assim, é reportado na literatura que solos de vegetação natural, principalmente florestas, possuem um potencial de dreno de metano até três vezes maior do que solos voltados para a agricultura, devido, entre outros fatores, pela maior riqueza e atividade microbiológica do solo natural (AKIYAMA et al., 2014).

Não foram observadas diferenças estatisticamente significativas nos tratamentos de elevada $\left[\mathrm{CO}_{2}\right]$ e temperatura quanto ao metano do solo. Em um estudo com gramíneas, Mosier et al. (1996) observaram que a adição de ureia no solo levou a uma diminuição na oxidação de metano e consequente menor fixação de metano no solo (MOSIER et al., 1996). Esse efeito foi atribuído à estimulação de bactérias oxidantes de amônia, que levou à diminuição da atividade de bactérias oxidantes de metano por competição, no entanto, os mecanismos envolvidos nesse processo ainda são obscuros (SMITH et al., 2000). A concentração de nitrogênio do solo do experimento com $S$. capitata foi corrigida com ureia e isso pode ter afetado a capacidade das bactérias metanotróficas, como sugerido na literatura. 
É provável que a agricultura moderna continue utilizando insumos como a ureia na manutenção de nitrogênio do solo, no entanto, com os resultados deste trabalho, é possível inferir que um cenário futuro de $+2^{\circ} \mathrm{C} \mathrm{e} 600 \mathrm{ppm}$ de $\mathrm{CO}_{2}$ atmosférico não causará mudanças na capacidade do solo de pastagem com S. capitata como dreno de metano. Assim, pastagens tropicais com essa espécie poderão manter o potencial como mitigadores do aquecimento global, por retirarem metano da atmosfera, ainda que em menor quantidade que solos naturais. 


\subsection{Conclusão}

Os tratamentos de elevada $\left[\mathrm{CO}_{2}\right]$ e temperatura causaram mudanças no ciclo do carbono no ecossistema de pastagem composto por $S$. capitata. A diminuição na biomassa de folhas e inflorescência no grupo eT pode significar uma aceleração da fenologia das plantas, já em processo de senescência.

Já o aumento da biomassa de caules e do NEE diurno sob eCeT e eC, respectivamente, pode estar relacionado com uma maior disponibilidade de $\mathrm{CO}_{2}$ atmosférico sendo fixado pelas plantas e alocado para órgãos estruturais já em um novo ciclo vegetativo.

A respiração do solo durante a noite também foi elevada pelos tratamentos eC, eT e eCeT, provavelmente pela maior respiração autotrófica de raízes e pelo aumento da atividade heterotrófica, devido a maior temperatura e efeito priming.

Já o metano manteve sua taxa inalterada pelos tratamentos e se comportou como dreno de carbono no ecossistema, pela atividade oxidante de bactérias metanotróficas.

Para a pecuária extensiva tropical, esses dados podem significar que pastagens com $S$. capitata no futuro precisarão de manejos diferenciados, por mudanças na fenologia da planta. Devido a maior alocação de biomassa para o caule, a eficiência dessa planta como meio de produção de alimento para o gado poderá ser alterada. 


\section{EXPERIMENTO II}

\subsection{Delineamento Experimental}

O experimento ocorreu de 19/11/2015 a 18/12/2015, utilizando Panicum maximum Jacq. cv Mombaça em tratamentos de elevada $\left[\mathrm{CO}_{2}\right]$ e temperatura. Totalizando 29 dias de tratamento.

P. maximum é uma gramínea de via fotossintética $\mathrm{C}_{4}$, de origem africana, amplamente utilizada como pastagem no Brasil. Estima-se que esta espécie ocupe aproximadamente $20 \%$ de toda área de pastagem no País. Seu uso é adequado a sistemas agroflorestais e em consórcios com outros grupos de plantas devido a sua eficiente produção de biomassa, plasticidade em relação à luz e resistência à climas quentes e secos (PEREIRA et al., 2011).

Após o preparo do solo, os indivíduos foram igualmente semeados a lanço em todas as parcelas e cultivados em condições ambiente, com rega, por cerca de 75 dias. Após este período, foi realizado um corte de uniformização a $40 \mathrm{~cm}$ do solo e dado início aos tratamentos.

O delineamento experimental foi organizado em quatro blocos. Cada bloco possuía quatro unidades experimentais, chamadas de parcelas, contendo combinações dos tratamentos (Figura 11):

○ $\mathrm{aC}-\left[\mathrm{CO}_{2}\right]$ ambiente: concentração ambiente de $\mathrm{CO}_{2}$, aproximadamente $400 \mathrm{ppm}$;

$\circ$ eC - $\left[\mathrm{CO}_{2}\right]$ elevada: $50 \%$ acima da concentração ambiente, aproximadamente 600 ppm;

○ aT - Temperatura ambiente: temperatura atmosférica do ambiente;

○ eT - Temperatura elevada: $2{ }^{\circ} \mathrm{C}$ acima da temperatura ambiente.

As avaliações foram efetuadas de 21 a 29 dias após o início dos tratamentos, tempo no qual ocorre a rebrota e formação de nova biomassa. 
SISTEMAS FACE E T-FACE USP/CAMPUS RIBEIRÃO PRETO
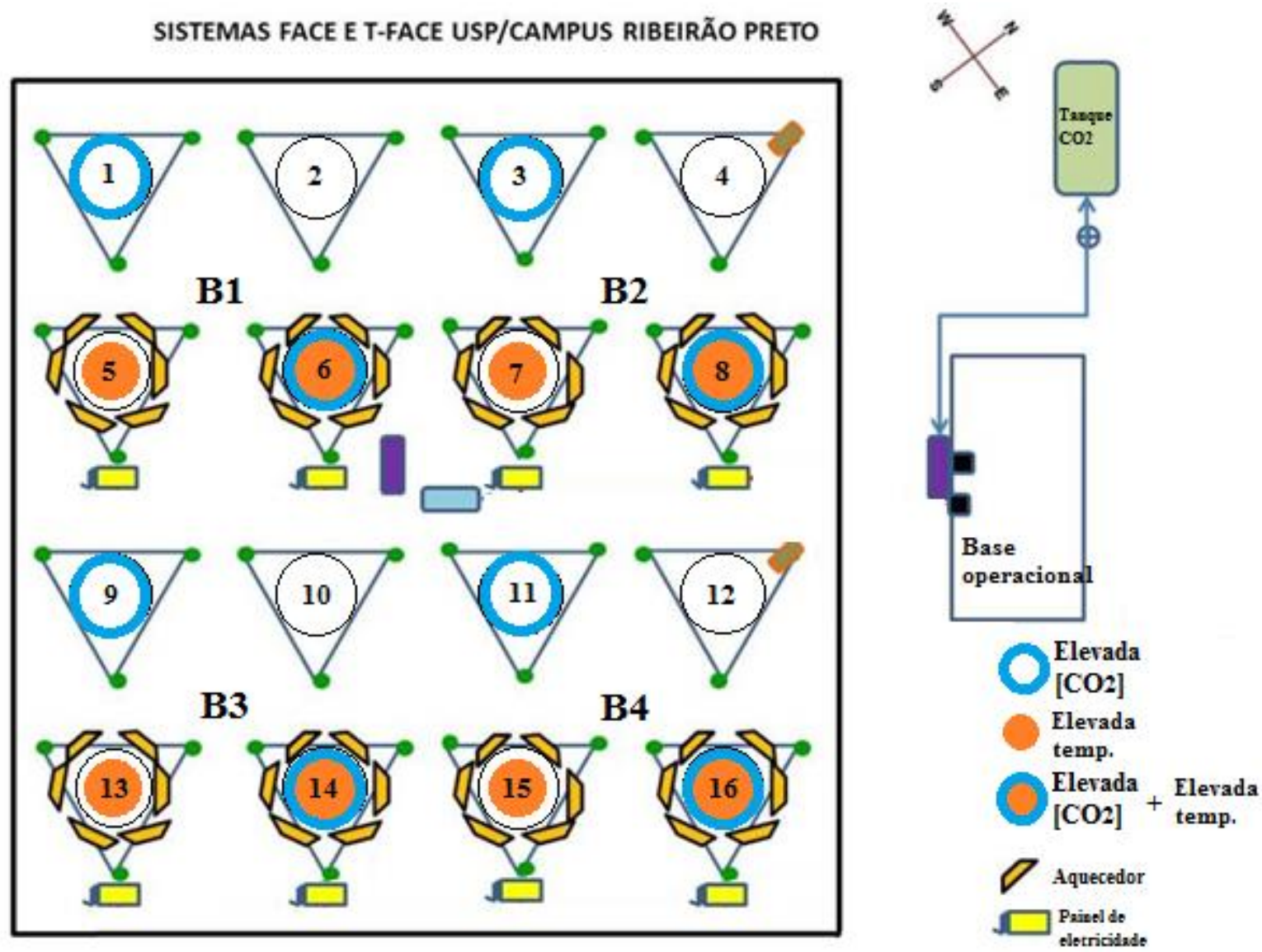

Figura 11: Esquema ilustrativo do campo experimental, evidenciando as 16 parcelas com tratamentos de elevada $\left[\mathrm{CO}_{2}\right]$, elevada temperatura e elevada $\left[\mathrm{CO}_{2}\right]+$ temperatura. As parcelas foram divididas em 4 blocos contendo as diferentes combinações de tratamento. 


\subsection{Resultados}

O experimento com P. maximum ocorreu durante o Verão de 2015, com início no dia 19 de novembro e final em 18 de dezembro, totalizando 29 dias de tratamento. A temperatura média do ar do período experimental foi de $24,4^{\circ} \mathrm{C}$, sendo que no mês de novembro (entre os dias 19 e 30) a temperatura máxima foi de $34,7^{\circ} \mathrm{C}$, a mínima de $16,4^{\circ} \mathrm{C}$ e a média mensal de $23,7^{\circ} \mathrm{C}$. Enquanto que no mês de dezembro (entre os dias 1 e 18 ) a temperatura máxima foi de $34,9{ }^{\circ} \mathrm{C}$, a mínima de $18,8^{\circ} \mathrm{C}$ e média mensal de $24,8^{\circ} \mathrm{C}$. O valor médio da umidade relativa do ar foi de $86,9 \%$. No mês de novembro foi registrada umidade relativa do ar mínima de 43,8\% e média mensal de $88,2 \%$. Em dezembro, a média mensal da umidade relativa do ar foi de $86,1 \%$ e mínima de $37,7 \%$. A precipitação total do período no qual o experimento foi realizado foi de 223,9 mm com média diária de 7,7 mm/dia (Figura 12).

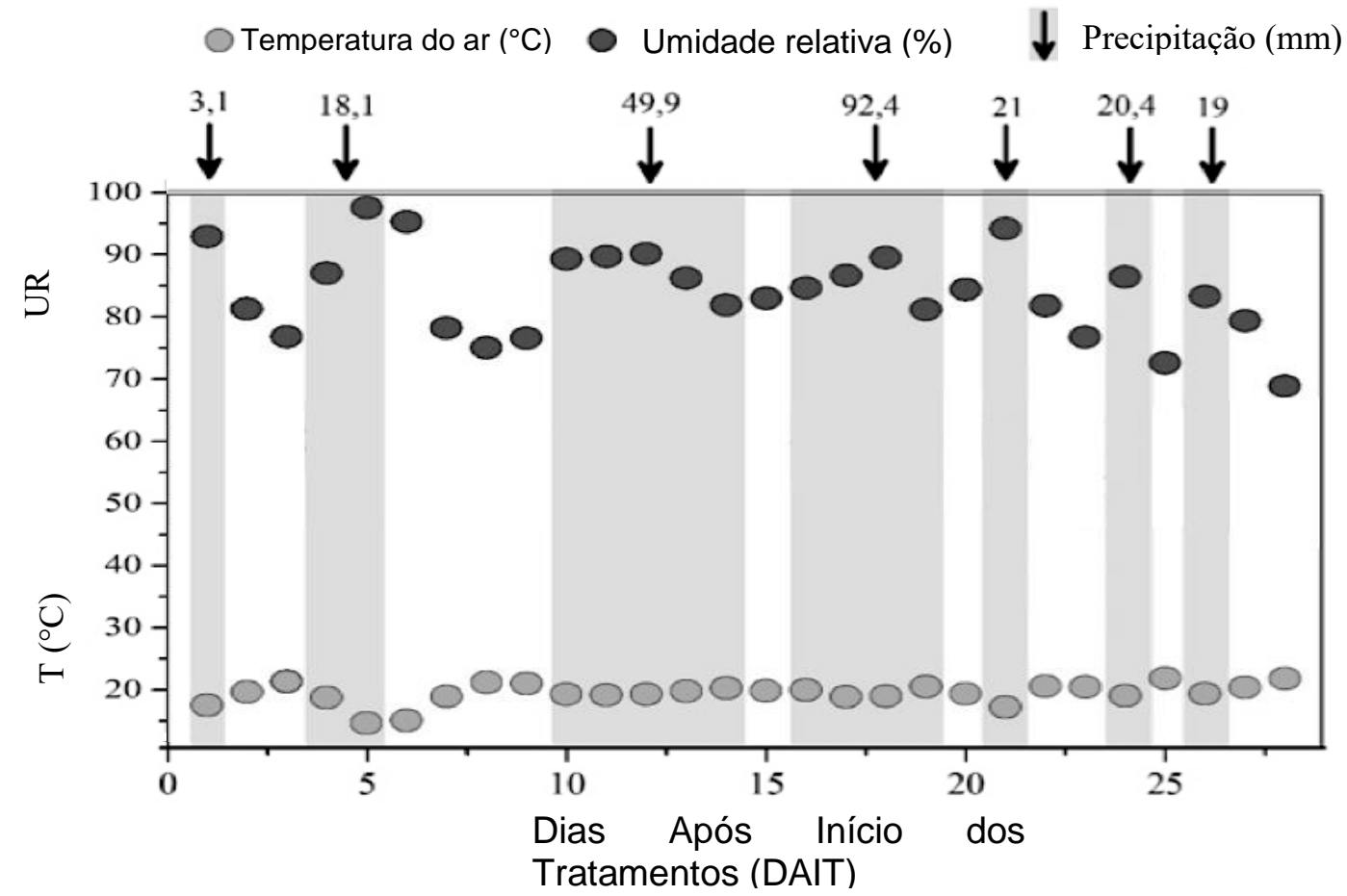

Figura 12: Médias diárias de temperatura do $\operatorname{ar}\left({ }^{\circ} \mathrm{C}\right)$, umidade relativa do ar $(\%)$ e precipitação $(\mathrm{mm})$ registradas durante o período experimental com $P$. maximum em sistema T-FACE. As setas e bandas cinzas mostram as precipitações ocorridas durante o experimento e dias de chuvas consecutivos foram condensados. O experimento ocorreu de 19/11/2015 a 18/12/2015, totalizando 29 dias de tratamento.

A única alteração de biomassa em P. maximum foi observada nas folhas sob tratamento combinado em relação ao controle $(\mathrm{p}=0,0433)$. Não houve nenhum efeito da elevada $\left[\mathrm{CO}_{2}\right]$ e temperatura na biomassa de folhas $(\mathrm{p}=0,0872$ e $\mathrm{p}=0,1385$, respectivamente) (Figura 13A). A biomassa de caules também não sofreu nenhuma alteração pelos tratamentos de elevada $\left[\mathrm{CO}_{2}\right]$ 
$(\mathrm{p}=0,4437)$, temperatura $(\mathrm{p}=0,6084)$ e tratamento combinado $(\mathrm{p}=0,3004)$ (Figura 13B). Mesmo com o aumento da biomassa de folhas sob tratamento combinado, a biomassa total acima do solo em $P$. maximum não foi alterada pelo aumento da $\left[\mathrm{CO}_{2}\right](\mathrm{p}=0,1642)$, temperatura $(p=0,2561)$ e tratamento combinado $(p=0,0884)$ (Figura 13C). 

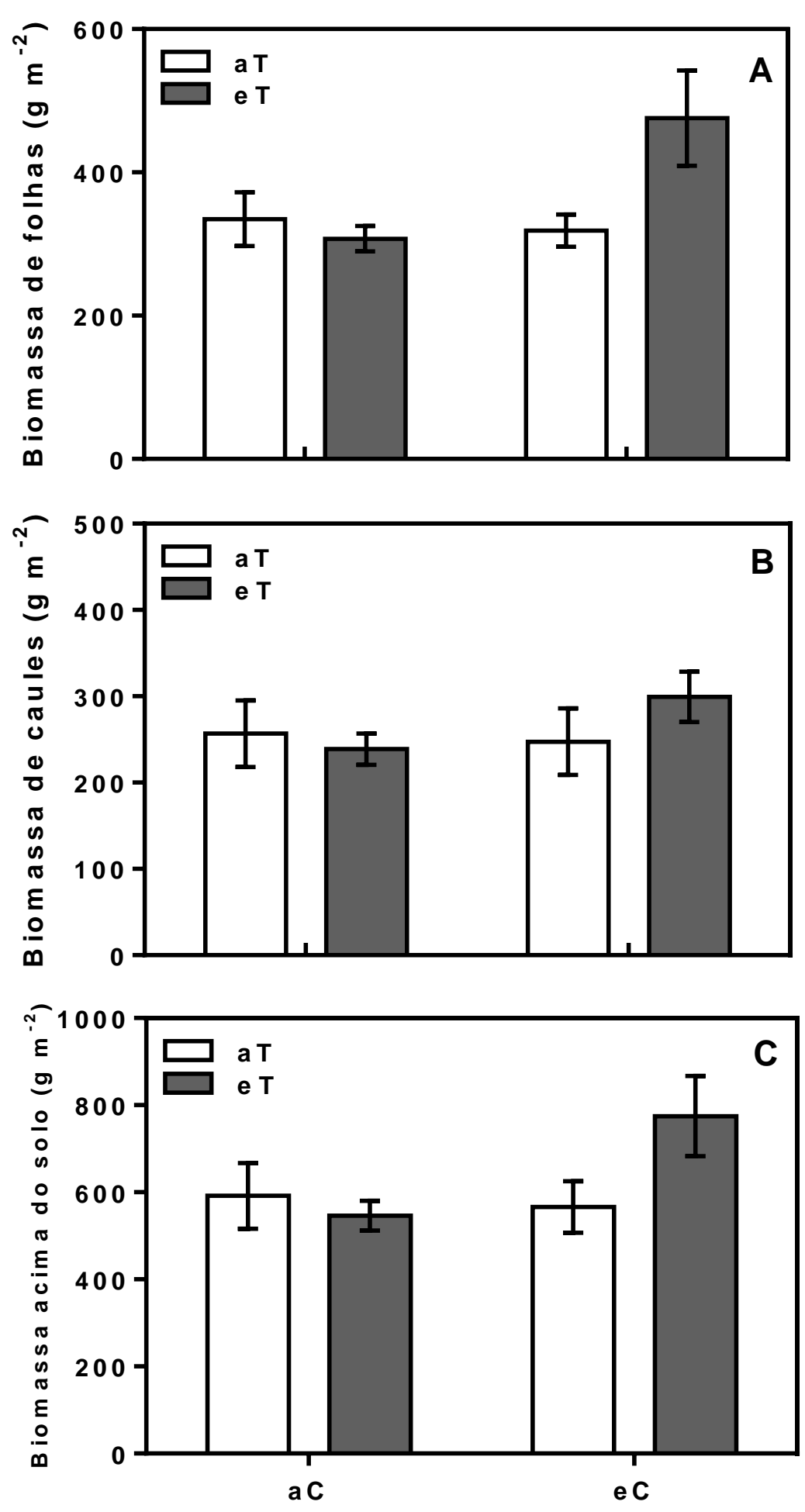

Figura 13: (A) Biomassa de folhas, (B) biomassa de caules e (C) biomassa total acima do solo em $\mathrm{g} \mathrm{m}^{-2}$ de $P$. maximum ao final do experimento sob tratamentos combinados de $\left[\mathrm{CO}_{2}\right]$ ambiente $(\mathrm{aC}),\left[\mathrm{CO}_{2}\right]$ elevada $(\mathrm{eC})$, temperatura ambiente (aT), e temperatura elevada (eT) em sistema T-FACE. 
O fluxo líquido de carbono do ecossistema no período diurno aumentou com tratamento de elevada $\left[\mathrm{CO}_{2}\right](\mathrm{p}=0,0051)$, e foi inalterado nos tratamentos de elevada temperatura $(\mathrm{p}=$ $0,8510)$ e combinado $(\mathrm{p}=0,1733)$ (Figura 14A). Os tratamentos de elevada $\left[\mathrm{CO}_{2}\right](\mathrm{p}=0,08)$, temperatura $(\mathrm{p}=0,455)$ e tratamento combinado $(\mathrm{p}=0,099)$ não modificaram o NEE no período noturno (Figura 14B).
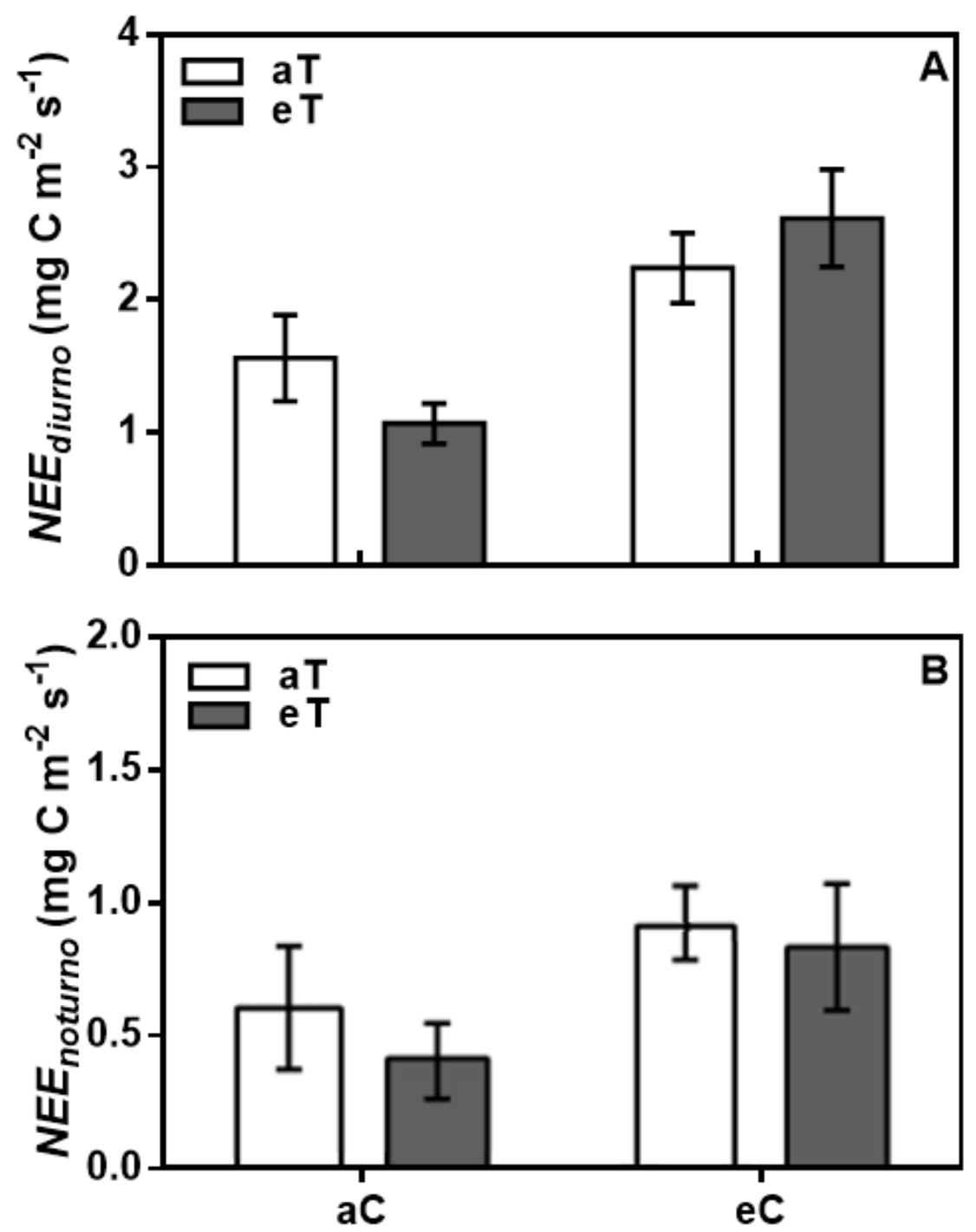

Figura 14: (A) Fluxo líquido de carbono do ecossistema durante período diurno, medido às 12:00 horas, e (B) período noturno, medido às 21:00 horas, em $\mathrm{mg}$ de carbono $\mathrm{m}^{-2} \mathrm{~s}^{-1}$, utilizando câmara de topo aberto em $P$. maximum sob condições de ambiente $\left[\mathrm{CO}_{2}\right](\mathrm{aC})$, elevada $\left[\mathrm{CO}_{2}\right](\mathrm{eC})$, temperatura ambiente $(\mathrm{aT})$ e temperatura elevada (eT) em sistema T-FACE. Média \pm erro padrão. 
A respiração do solo diurno não foi alterada pelos tratamentos de elevada $\left[\mathrm{CO}_{2}\right](\mathrm{p}=$ 0,2122), temperatura $(\mathrm{p}=0,6709)$ e tratamento combinado $(\mathrm{p}=0,6517)$ (Figura 15A). Já na respiração do solo noturno, não houveram alterações nos tratamentos de elevada $\left[\mathrm{CO}_{2}\right](\mathrm{p}=$ $0,2019)$ e temperatura $(\mathrm{p}=0,7180)$, porém, houve aumento da respiração do solo no tratamento combinado em relação ao controle $(\mathrm{p}=0,005)$ (Figura 15B).
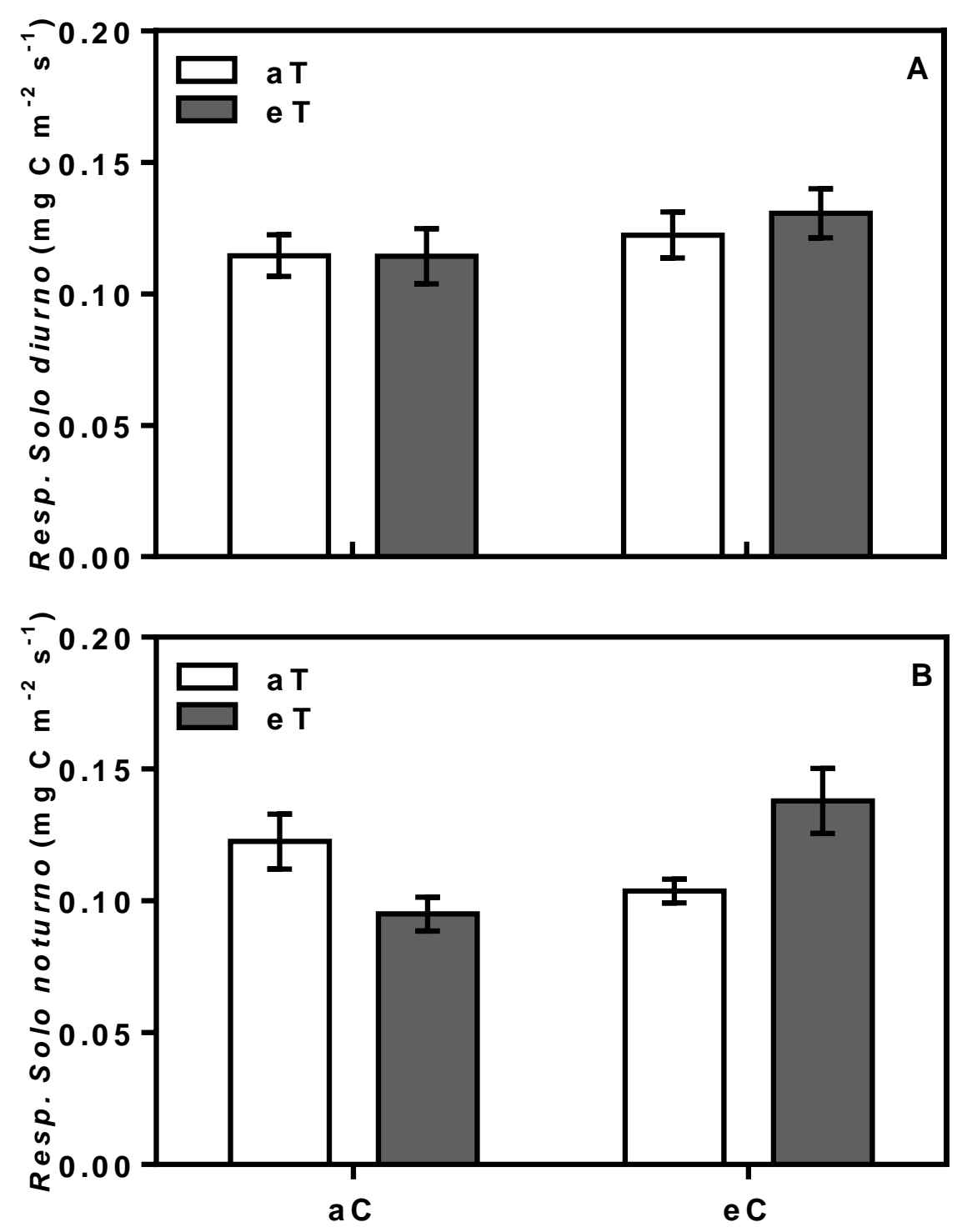

Figura 15: (A) Respiração do solo durante o período luminoso (12:00 horas) e (B) respiração do solo durante o período noturno (21:00 horas) em $\mathrm{mg}$ de carbono $\mathrm{m}^{-2} \mathrm{~s}^{-1}$. Medições realizadas em solo sem plantas, em condições de ambiente $\left[\mathrm{CO}_{2}\right](\mathrm{aC})$, elevada $\left[\mathrm{CO}_{2}\right](\mathrm{eC})$, temperatura ambiente (aT) e temperatura elevada (eT) em sistema T-FACE. Média \pm erro padrão. 
Não foram observadas mudanças nas taxas de fixação de metano nos tratamentos de elevada $\left[\mathrm{CO}_{2}\right](\mathrm{p}=0,2399)$, temperatura $(\mathrm{p}=0,8210)$ e tratamento combinado $(\mathrm{p}=0,9626)$, com valores próximos de zero (Figura 16).

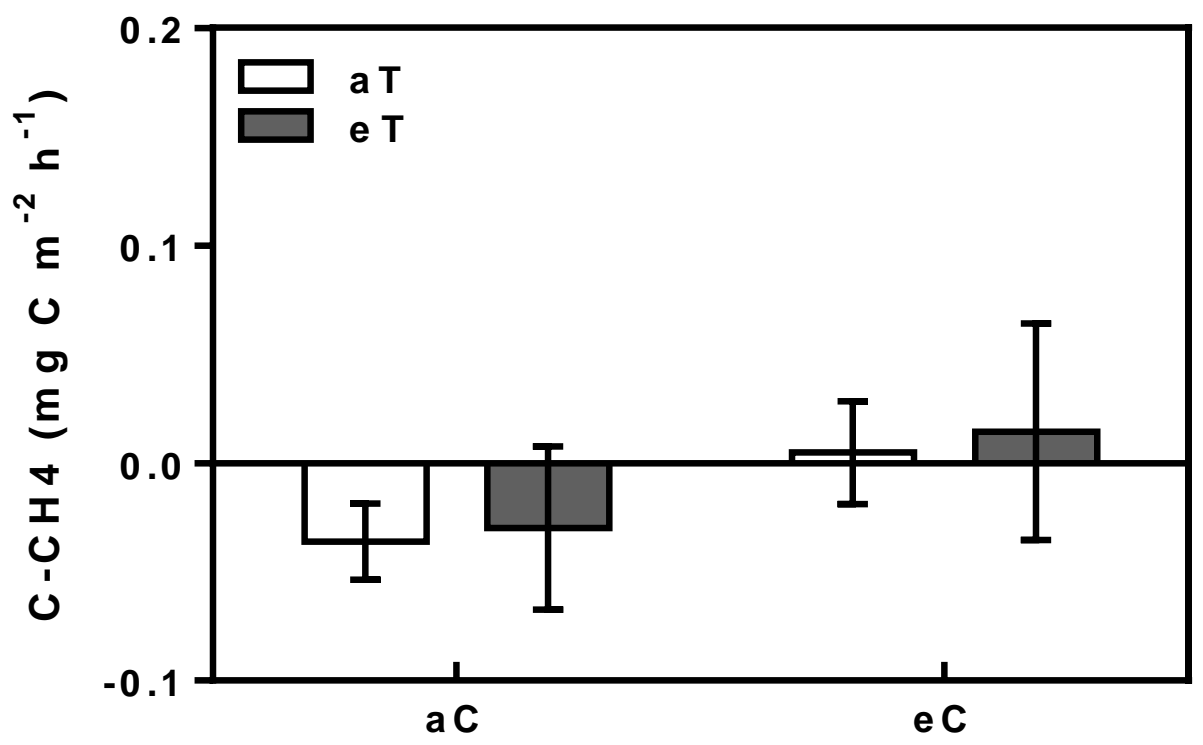

Figura 16: Fluxo de metano $\left(\mathrm{CH}_{4}\right)$ do solo em $\mathrm{mg} \mathrm{C} \mathrm{m}^{-2} \mathrm{~h}^{-1}$ sob cultivo de $P$. maximum em condições de ambiente $\left[\mathrm{CO}_{2}\right](\mathrm{aC})$, elevada $\left[\mathrm{CO}_{2}\right](\mathrm{eC})$, temperatura ambiente $(\mathrm{aT})$ e temperatura elevada (eT) em sistema T-FACE. Média \pm erro padrão. 


\subsection{Discussão}

De forma oposta ao observado no experimento com $S$. capitata, no experimento com a gramínea $\mathrm{C}_{4} P$. maximum houve um aumento na biomassa de folhas em tratamento combinado de elevada $\left[\mathrm{CO}_{2}\right]$ e temperatura. $P$. maximum é uma gramínea de rápido crescimento e com alta alocação de biomassa para as folhas, que agem como um dreno forte. Ainda assim, é de se esperar um menor efeito da fertilização atmosférica de $\mathrm{CO}_{2}$ em plantas $\mathrm{C}_{4}$, por possuírem um mecanismo de bombeamento ativo de $\mathrm{CO}_{2}$ intracelular, tornando-as menos dependente da concentração atmosférica do gás carbônico. No entanto, é amplamente reportado na literatura o efeito positivo do enriquecimento de $\mathrm{CO}_{2}$ atmosférico na biomassa de espécies $\mathrm{C}_{4}$, principalmente por mudanças anatômicas nas folhas e maior eficiência do usa da água (DRAKE; GONZALEZ-MELER; LONG, 1997; NORBY et al., 1999; UPRETY et al., 2006).

Como sugerido pela hipótese deste trabalho, a elevação da temperatura ambiente isoladamente não afetou a biomassa de $P$. maximum, indicando que essa é uma espécie resistente à altas temperaturas. Porém, a temperatura elevada pode ter acelerado a fenologia das plantas, assim como sugerido em $S$. capitata, por apresentar maior biomassa de folhas quando combinada a elevação da temperatura e $\left[\mathrm{CO}_{2}\right]$.

Estudos do impacto da elevada $\left[\mathrm{CO}_{2}\right]$ e temperatura em plantas são comumente executados por um semestre ou mais, devido ao tempo necessário para que os tratamentos sejam convertidos em mudanças estruturais e fisiológicas nos indivíduos (AINSWORTH; LONG, 2005; DRAKE; GONZALEZ-MELER; LONG, 1997). No entanto, como esse trabalho tem em foco o manejo de pastos como é feito pelos pecuaristas e indicado pela EMBRAPA, o tempo de experimento seguiu o ciclo de descanso do pasto como é feito na prática, que leva de 30 a 60 dias (EUCLIDES et al., 2008).

Dessa forma, neste período de tempo, é possível que tenha sido observado apenas aumento na biomassa de folhas sob eCeT pois este seria um primeiro efeito, sendo que mudanças estruturais de caule e em tratamentos com apenas a elevação de $\mathrm{CO}_{2}$ poderiam ser observados em maior prazo.

No entanto, Lee (2011) em um estudo com a gramínea $\mathrm{C}_{4}$ Setaria viridis sob elevada temperatura e $\left[\mathrm{CO}_{2}\right]$, observou aumento de biomassa total a longo prazo, cerca de 5 meses, somente no grupo com tratamento combinado de $+4^{\circ} \mathrm{C}$ e $+80 \%\left[\mathrm{CO}_{2}\right]$, foi também reportado estágio fenológico avançado das plantas sob elevada temperatura (LEE, 2011). 
O experimento deste trabalho teve a duração de 29 dias, seguindo a indicação de manejo da empresa criadora do cultivar em estudo, e, portanto, não foi o objetivo investigar um efeito a longo prazo dos tratamentos sob a biomassa. Porém, como fonte de dados para a pecuária, é possível afirmar que pastagens tropicais com P. maximum sob manejo rotacional podem ser beneficiadas pelas mudanças climáticas previstas para o futuro não só por resistirem à elevação da temperatura, mas também por terem uma maior produção de biomassa foliar em um ambiente de maior $\left[\mathrm{CO}_{2}\right]$ e temperatura.

Assim com observado em $S$. capitata, não houve mudança na troca líquida de carbono do ecossistema durante a noite nos tratamentos com elevada $\left[\mathrm{CO}_{2}\right]$ e temperatura. Acessar o NEE durante o período noturno, quando não ocorre fotossíntese, mostrou que a respiração autotrófica acima do solo noturna não foi impactada pelos tratamentos. Mesmo sem enriquecimento de $\mathrm{CO}_{2}$ durante a noite, é possível inferir que o tratamento com elevada $\left[\mathrm{CO}_{2}\right]$ durante o dia não causou mudanças estruturais e fisiológicas nas plantas que alterassem a respiração autotróficas durante a noite. O mesmo pode ser inferido para a temperatura, mesmo sendo mantida elevada durante a noite, não causou mudanças no NEE.

Em um trabalho com objetivo de determinar a temperatura base de crescimento para diversos cultivares do gênero Panicum, Moreno et. al. determinou que para $P$. maximum é necessário uma temperatura base diária de $15^{\circ} \mathrm{C}$, dessa forma, como o experimento deste trabalho foi realizado no verão, mesmo nos grupos sem elevada temperatura já foi alcançada a temperatura base de crescimento, assim, a elevação da temperatura não foi um diferencial para um aumento da fixação de carbono (MORENO et al., 2014)

Apesar de $P$. maximum ser uma $\mathrm{C}_{4}$ e do experimento ter durado 29 dias, houve um aumento do NEE diurno sob elevada $\left[\mathrm{CO}_{2}\right]$, como também observado em S. capitata. Esse resultado pode ser atribuído ao fato de se tratar de uma gramínea de rápido crescimento e acumulo de biomassa em solo fértil, dessa forma, o $\mathrm{CO}_{2}$ em maior disposição na atmosfera pôde ser aproveitado de forma eficiente (PEREIRA et al., 2011).

No entanto, não foram observados efeitos da elevada temperatura no NEE diurno, como previsto na hipótese deste trabalho, pois as gramíneas do gênero Panicum são derivadas de plantas adaptadas a climas quentes e secos da África (EHLERINGER; CERLING; HELLIKER, 1997).

O resultado de maior biomassa de folhas em eCeT pode estar correlacionado com os valores elevados de NEE diurno em elevada $\left[\mathrm{CO}_{2}\right]$. Um argumento discutido na literatura afirma que o possível impacto positivo na produtividade de plantas $\mathrm{C}_{4}$ pelo enriquecimento de 
$\mathrm{CO}_{2}$ atmosférico ocorre não pela maior taxa fotossintética, mas sim pela maior eficiência do uso do carbono, água e nitrogênio (DRAKE; GONZALEZ-MELER; LONG, 1997). Esses efeitos ocorrem principalmente pois a abertura estomática é menor em plantas sob elevada $\left[\mathrm{CO}_{2}\right]$ sem diminuir a taxa fotossintética, uma vez que a concentração intracelular de $\mathrm{CO}_{2}$ se mantém inalterada em plantas sob elevada $\left[\mathrm{CO}_{2}\right]$ e com o benefício de menor perda de água pela evapotranspiração. Além disso, uma menor quantidade de Rubisco é necessária no funcionamento pleno da fotossíntese em um ambiente com maior $\left[\mathrm{CO}_{2}\right]$, dessa forma, menos nitrogênio é utilizado para formação dessas moléculas, que representam de 5 a $40 \%$ do conteúdo total proteico em plantas (LONG et al., 2005).

Para a pecuária tropical, os dados obtidos neste experimento mostram que o ecossistema de pastagem com $P$. maximum pode tolerar uma elevação da temperatura ambiente em $2^{\circ} \mathrm{C}$ sem perder sua capacidade de fixação de carbono, e se beneficiaria da elevação da $\left[\mathrm{CO}_{2}\right]$, aumentando a taxa de fixação de carbono pelo ecossistema e convertendo esse carbono em biomassa de folhas.

Com maior fixação de carbono pelo ecossistema durante o dia, seguido de uma maior produção de biomassa de folhas, a respiração do solo também foi maior no tratamento combinado eCeT. No entanto, assim como no experimento com $S$. capitata e como observado em um experimento anterior do mesmo grupo de trabalho também utilizando P. maximum, esse aumento foi somente observado na respiração do solo noturno (SILVA, 2014).

É possível que haja uma relação entre a maior fixação de carbono observada no NEE diurno sob elevada $\left[\mathrm{CO}_{2}\right]$ com a maior biomassa de folhas e respiração do solo em eCeT. O carbono extra fixado pelo ecossistema estaria sendo alocado para folhas e também influenciando a respiração abaixo do solo, por efeitos diretos nas raízes e indiretos na microbiota do solo - efeito priming.

Diversos estudos reportam efeitos tanto da elevação da $\left[\mathrm{CO}_{2}\right]$ quanto da temperatura no aumento da respiração do solo (FIELD et al., 2007; SCHLESINGER; ANDREWS, 2000). Em uma meta-análise utilizando 32 locais, de diferentes biomas e inclusive pastagens, Rustad et al. descreveram um aumento de $20 \%$ na respiração do solo em ecossistemas com elevada temperatura (RUSTAD et al., 2001).

De acordo com a literatura, a elevação da temperatura e da $\left[\mathrm{CO}_{2}\right]$ na respiração do solo estão associados com a maior taxa fotossintética das plantas, que leva a uma maior alocação de carbono na forma de biomassa e compostos carbônicos nas raízes, como exsudatos, aumentando a respiração autotrófica abaixo do solo e consequentemente a respiração heterotrófica, por 
disponibilizar mais matéria orgânica e facilitar os processos metabólicos para a microbiota do solo (CARRILLO et al., 2011; PENDALL et al., 2001; SMITH et al., 2008b).

No âmbito da agropecuária, esses resultados mostram que as mudanças climáticas podem acentuar o potencial do solo de pastagem com $P$. maximum como fonte de $\mathrm{CO}_{2}$ para a atmosfera. Assim, diferentes técnicas de manejo do solo devem ser pensadas para o futuro, com objetivo de minimizar a resposta agravante do aquecimento global causado pela respiração do solo de pastagem.

O fluxo de metano do solo não foi alterado pelos tratamentos de elevada $\left[\mathrm{CO}_{2}\right]$ e temperatura. Apesar do mesmo resultado ter sido observado em $S$. capitata, em P. maximum os valores de metano do solo estiveram próximos de zero, o que significa que nesse tipo de pastagem o solo não exerce um papel de dreno de metano.

Apesar de não ter ocorrido uma diferença estatisticamente significante entre os tratamentos, é possível observar nos tratamentos com elevada $\left[\mathrm{CO}_{2}\right]$ uma tendência a valores positivos de metano. Como já discutido anteriormente, a elevação da $\left[\mathrm{CO}_{2}\right]$ pode levar a uma maior eficiência do uso do nitrogênio pelas plantas, dessa forma, mais nitrogênio estaria à disposição no solo para nitrobactérias e essas por sua vez estariam suprimindo a atividade das bactérias metanotróficas no solo por competição. Como argumentado por Smith (2000), esse processo ainda é desconhecido e precisa ser estudado mais profundamente (SMITH et al., 2000). 


\subsection{Conclusão}

$\mathrm{O}$ ecossistema de pastagem composto pela gramínea $P$. maximum sob elevada $\left[\mathrm{CO}_{2}\right]$ e temperatura sofreu mudanças em seu ciclo do carbono, principalmente pelo feito combinado dos tratamentos.

Houve maior acumulo de biomassa de folhas pelo tratamento combinado de elevada $\left[\mathrm{CO}_{2}\right]$ e temperatura. Esse resultado demonstra que, mesmo sendo uma $\mathrm{C}_{4}$, pastagens com $P$. maximum são capazes de fixar mais carbono em forma de biomassa em ambientes de maior $\mathrm{CO}_{2}$ atmosférico e temperatura. O maior NEE diurno encontrado no tratamento com elevada $\left[\mathrm{CO}_{2}\right]$ corrobora com esses dados.

A respiração do solo aumentou com o tratamento combinado, assim como em $S$. capitata, provavelmente por maior atividade auto e heterotrófica. Isso demonstra que os solos destas pastagens poderão ser maiores fontes de $\mathrm{CO}_{2}$ para a atmosfera no futuro, aumentando o efeito estufa causado por este gás.

O mesmo pode ser sugerido para o metano. Apesar de não terem sido observadas diferenças estatísticas entre os tratamentos, é possível que haja uma tendência a diminuição da atividade de bactérias metanotróficas no solo de pastagem composta por $P$. maximum sob elevada $\left[\mathrm{CO}_{2}\right]$. O que pode acarretar em maiores emissões de metano para a atmosfera.

A pecuária extensiva já utiliza amplamente $P$. maximum em suas pastagens. No cenário futuro é possível que essas pastagens sejam beneficiadas pelo aumento da biomassa de folhas sem perdas de eficiência pela maior temperatura. 


\section{EXPERIMENTO III}

\subsection{Delineamento Experimental}

O experimento ocorreu de 06/11/2016 a 19/12/2016, utilizando Panicum maximum Jacq. cv Mombaça em tratamentos de restrição hídrica e temperatura elevada. Totalizando 43 dias de tratamento.

$\mathrm{Na}$ execução do terceiro experimento foi utilizado o mesmo material vegetal do experimento anterior, constituído pela gramínea de tipo fotossintético $\mathrm{C}_{4} P$. maximum. Antes do início do experimento as plantas sofreram um corte de uniformização a cerca de $40 \mathrm{~cm}$ de altura e então foi dado início aos tratamentos.

O delineamento experimental foi organizado em quatro blocos, cada bloco possuía quatro unidades experimentais, chamadas de parcelas, contendo combinações dos tratamentos (Figura 17):

○ dh - Disponibilidade hídrica: parcela irrigada, umidade média do solo em torno de $0,5 \mathrm{~m}^{3} \mathrm{~m}^{-3}$;

○ $\mathrm{Rh}$ - Restrição hídrica: parcela não irrigada, fonte de água apenas da precipitação natural;

○ aT - Temperatura ambiente: temperatura atmosférica do ambiente;

○ eT - Temperatura elevada: $2{ }^{\circ} \mathrm{C}$ acima da temperatura ambiente. 

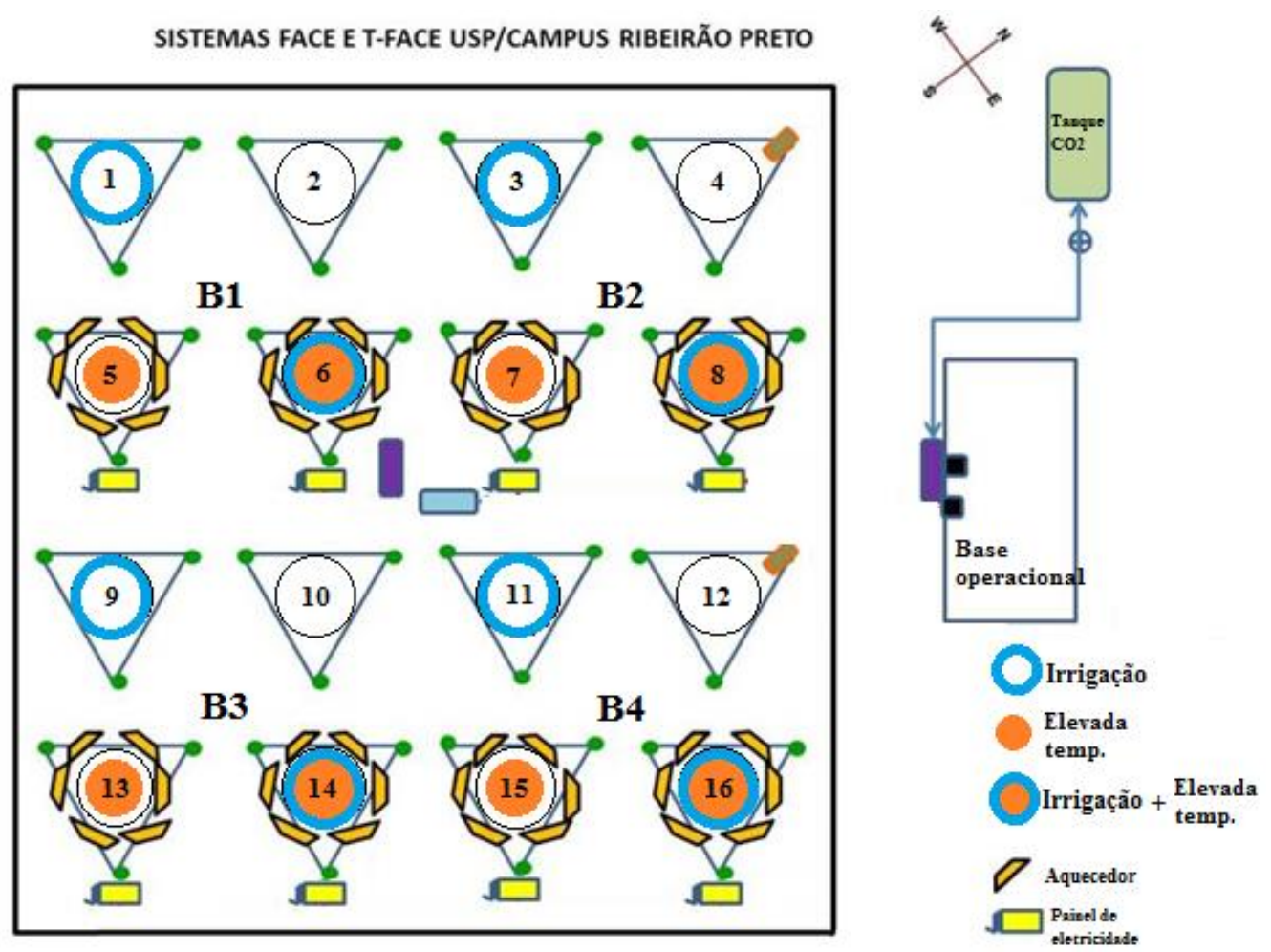

Figura 17: Esquema ilustrativo do campo experimental, evidenciando as 16 parcelas com tratamentos de restrição hídrica, elevada temperatura e restrição hídrica + temperatura. As parcelas foram divididas em 4 blocos contendo as diferentes combinações de tratamento.

\subsubsection{Sistema de Irrigação}

Em cada parcela foi instalado um aspersor na região central e a 1,5 metros de altura, de modo a possibilitar uma irrigação homogênea de toda a área tratada nos períodos em que o sistema era ligado. Durante o experimento, no período da tarde, o conteúdo de água no solo das parcelas dos grupos com disponibilidade hídrica era adquirido e analisado diariamente, utilizando sensores Theta Probe. As parcelas que apresentavam umidade de solo inferior a 0,45 $\mathrm{m}^{3} \mathrm{~m}^{-3}$, cerca de $80 \%$ da capacidade de campo, tiveram seu sistema de irrigação ligado durante a noite. No dia seguinte o procedimento era repetido e caso a umidade do solo continuasse abaixo de $0,45 \mathrm{~m}^{3} \mathrm{~m}^{-3} \mathrm{o}$ sistema era novamente ligado, de forma a manter a umidade do solo nos tratamentos com disponibilidade hídrica entre 0,45 e $0,55 \mathrm{~m}^{3} \mathrm{~m}^{-3}$. 


\subsection{Resultados}

O segundo experimento com $P$. maximum ocorreu também durante o verão, com início em 06 de novembro de 2016 e término em 19 de dezembro de 2016, e duração total de 43 dias. A temperatura média do ar durante o período experimental foi de $25,9^{\circ} \mathrm{C}$, sendo que a temperatura média no mês de novembro (entre os dias 06 e 30) foi de $25,8{ }^{\circ} \mathrm{C}$ enquanto que no mês de dezembro (entre os dias 1 e 18 ) a temperatura média foi de $26,1^{\circ} \mathrm{C}$. O valor médio da umidade relativa do ar foi de $81,7 \%$ no mês de novembro e $88,9 \%$ em dezembro, com média total do experimento de $84,8 \%$. A precipitação total do período no qual o experimento foi realizado foi de 304,7 mm com média diária de 7,1 mm/dia. A maior parte do volume precipitado ocorreu no começo do experimento, com 200,9 mm de chuva em novembro e 103,8 mm em dezembro (Figura 18).

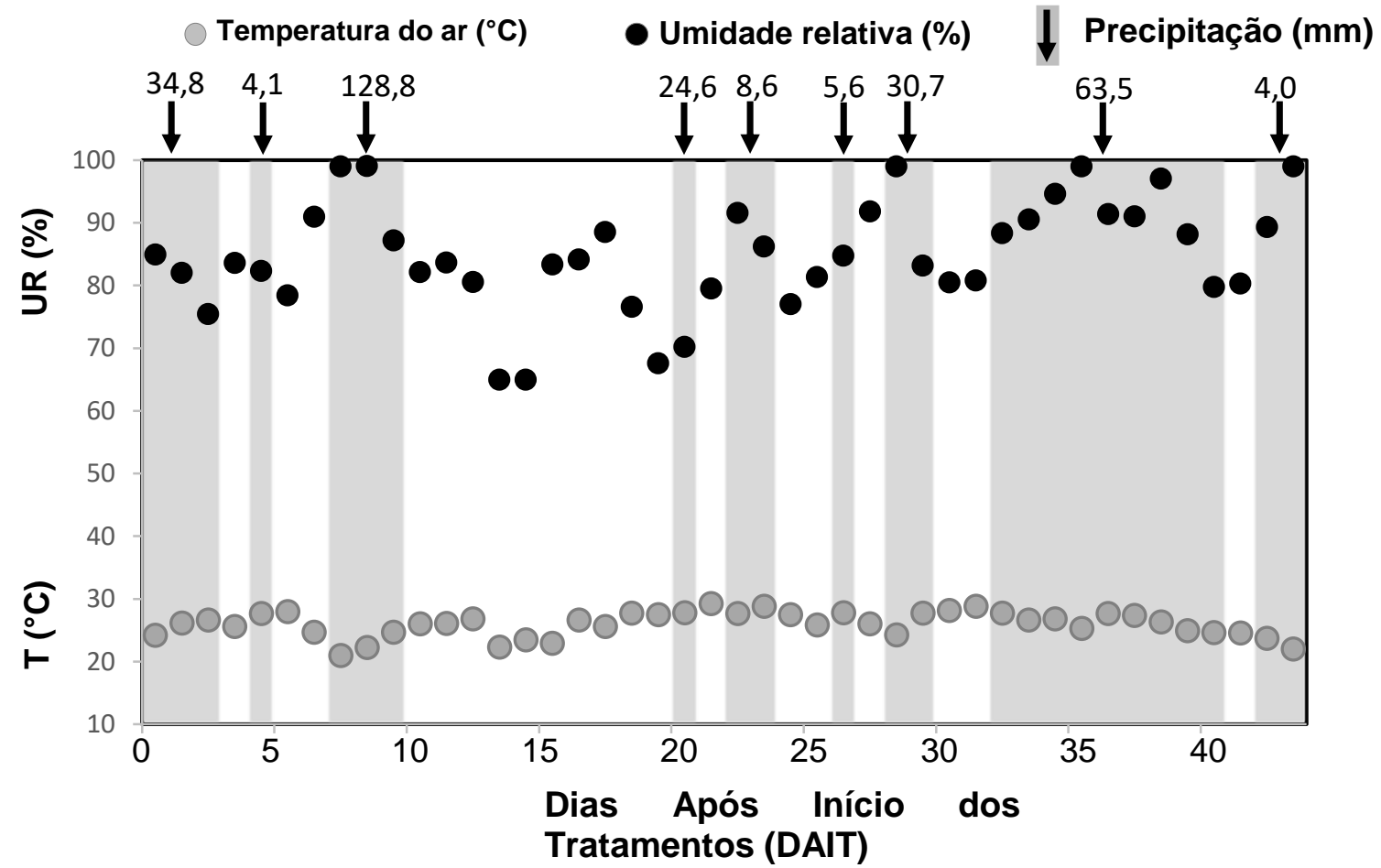

Figura 18: Médias diárias de temperatura do $\operatorname{ar}\left({ }^{\circ} \mathrm{C}\right)$, umidade relativa do ar $(\%)$ e precipitação (mm) registradas durante o período experimental com $P$. maximum em sistema T-FACE. As setas e bandas cinzas mostram as precipitações ocorridas durante o experimento e dias de chuvas consecutivos foram condensados. O experimento ocorreu de 06/11/2016 a 19/12/2016, totalizando 43 dias de tratamento. 
O conteúdo médio de água no solo se manteve entre 0,4 e $0,6 \mathrm{~m}^{3} \mathrm{~m}^{-3}$ nas parcelas com disponibilidade hídrica e entre 0,3 e $0,5 \mathrm{~m}^{3} \mathrm{~m}^{-3}$ nas parcelas com restrição hídrica, além disso, a maior diferença de conteúdo de água no solo entre os tratamentos $\mathrm{dH}$ e $\mathrm{rH}$ ocorreu no período entre o dia 19/11 e 28/11 (Figura 19). O conteúdo de água no solo durante todo experimento foi de $0,49 \mathrm{~m}^{3} \mathrm{~m}^{-3}$ nas parcelas com disponibilidade hídrica e $0,38 \mathrm{~m}^{3} \mathrm{~m}^{-3}$ nas parcelas sob restrição hídrica, sendo esses valores diferentes entre si $(\mathrm{p}<0,0001)$ (Figura 20).

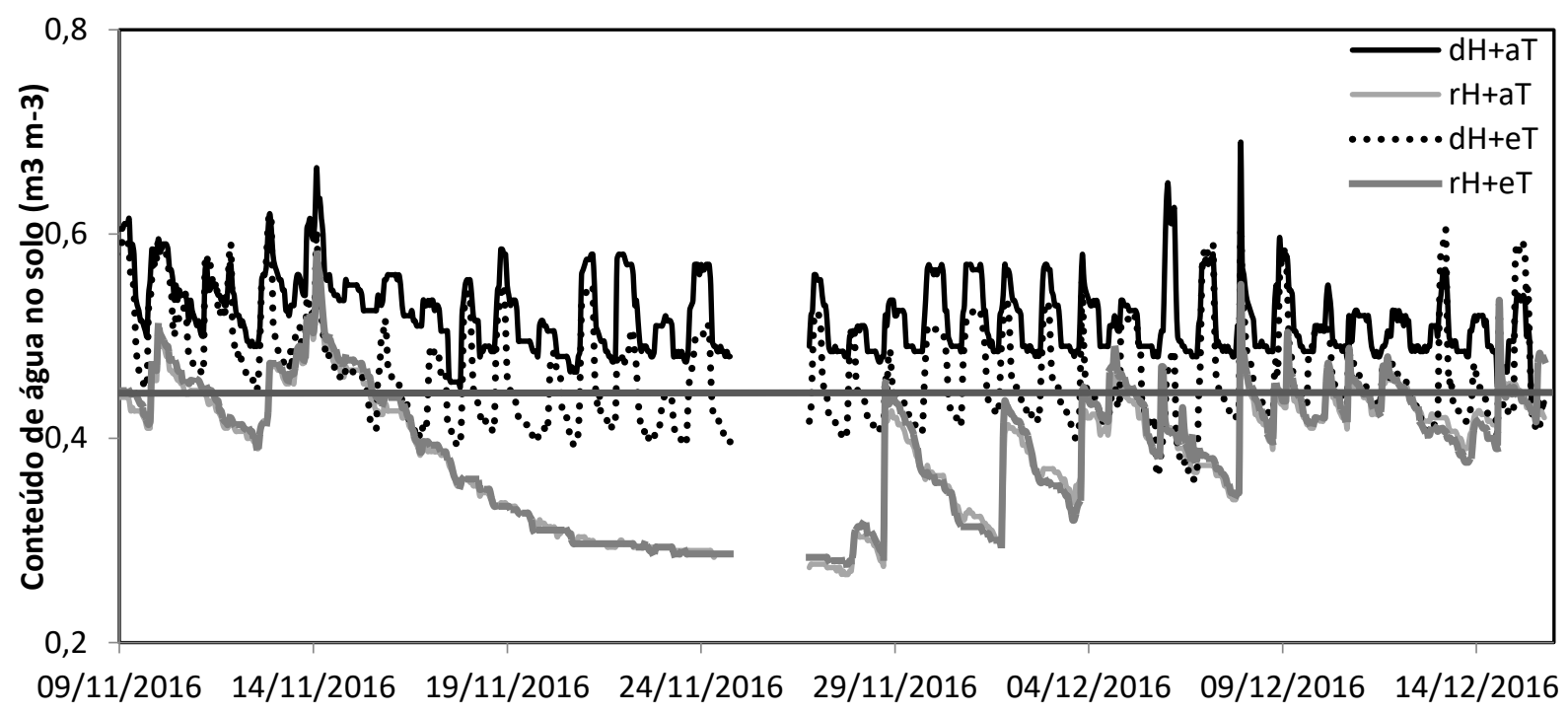

Figura 19: Conteúdo médio de água no solo $\left(\mathrm{m}^{3} \mathrm{~m}^{-3}\right)$ em cada tratamento ao longo do período experimental. O limite $\left(0,45 \mathrm{~m}^{3} \cdot \mathrm{m}^{-3}\right)$ utilizado para controlar a rega das parcelas sob disponibilidade hídrica está indicado no gráfico pela reta cinza. Durante 2 dias $(25 / 11$ e 26/11) os sensores falharam e marcaram valores não reais, não são apresentados os valores desse período no gráfico. Tratamentos: dH+aT: Disponibilidade Hídrica + Temperatura Ambiente; rH+aT: Restrição Hídrica + Temperatura Ambiente; dH+eT: Disponibilidade Hídrica + Elevada Temperatura; rH+eT: Restrição Hídrica + Elevada Temperatura. 


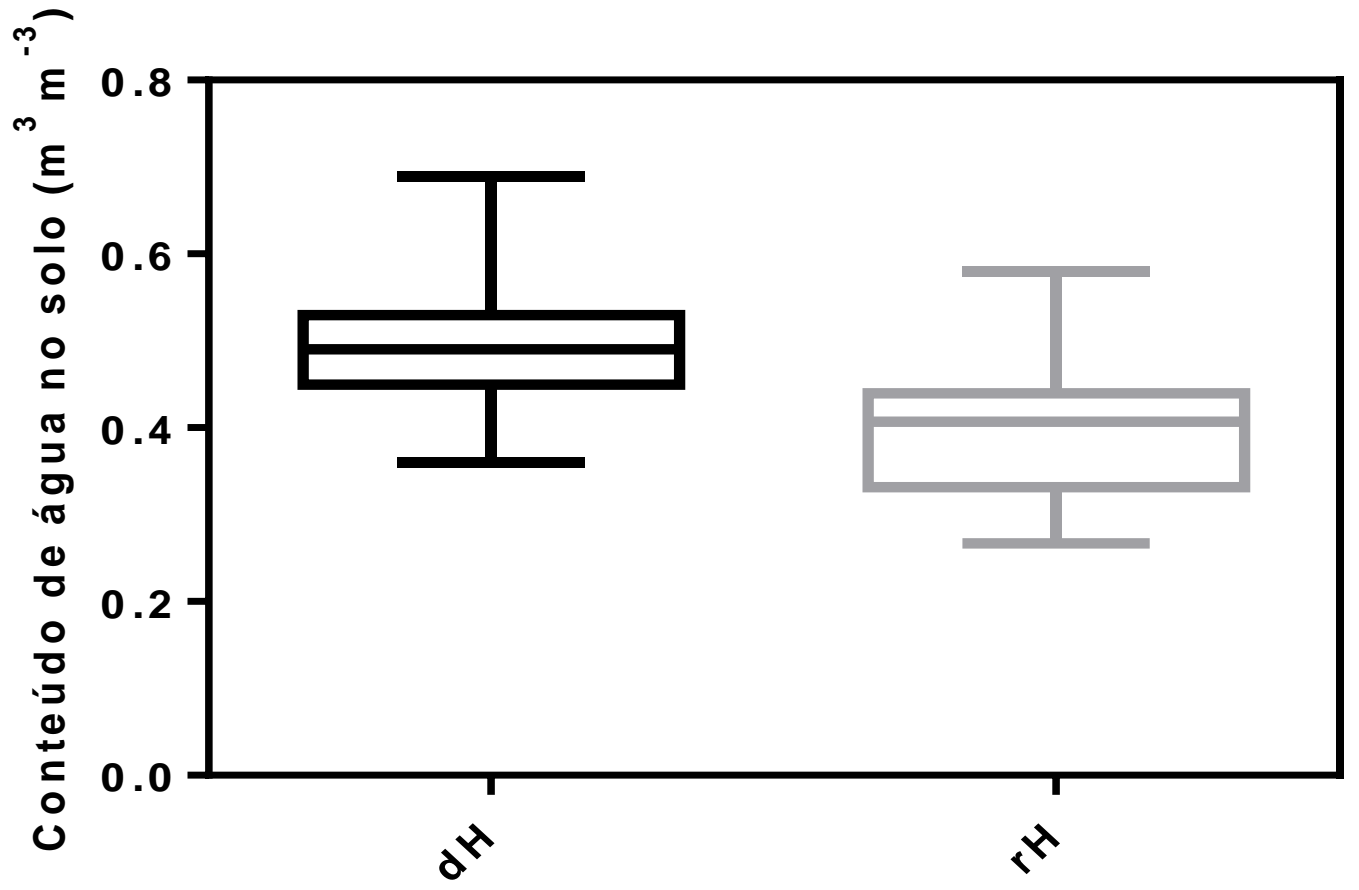

Figura 20: Média do conteúdo de água no solo $\left(\mathrm{m}^{3} \mathrm{~m}^{-3}\right)$ durante o período experimental nas parcelas com disponibilidade hídrica $(\mathrm{dH})$ e com restrição hídrica $(\mathrm{rH})$. Os dados de umidade do solo foram coletados de hora em hora em todas as parcelas durante todo o período experimental.

Tanto a biomassa de folhas quanto a de caules não foram alteradas pelos tratamentos de restrição hídrica $(\mathrm{p}=0,3486$ e $\mathrm{p}=0,2609)$, temperatura elevada $(\mathrm{p}=0,8948$ e $\mathrm{p}=0,6662)$ e tratamento combinado ( $\mathrm{p}=0,3992$ e $\mathrm{p}=0,4775)$ (Figuras 21A e 21B). Consequentemente, $\mathrm{a}$ biomassa total acima do solo também não sofreu alterações pelos tratamentos de restrição hídrica $(p=0,2989)$, temperatura elevada $(p=0,9084)$ e tratamento combinado $(p=0,4230)$ (Figura 21C). 

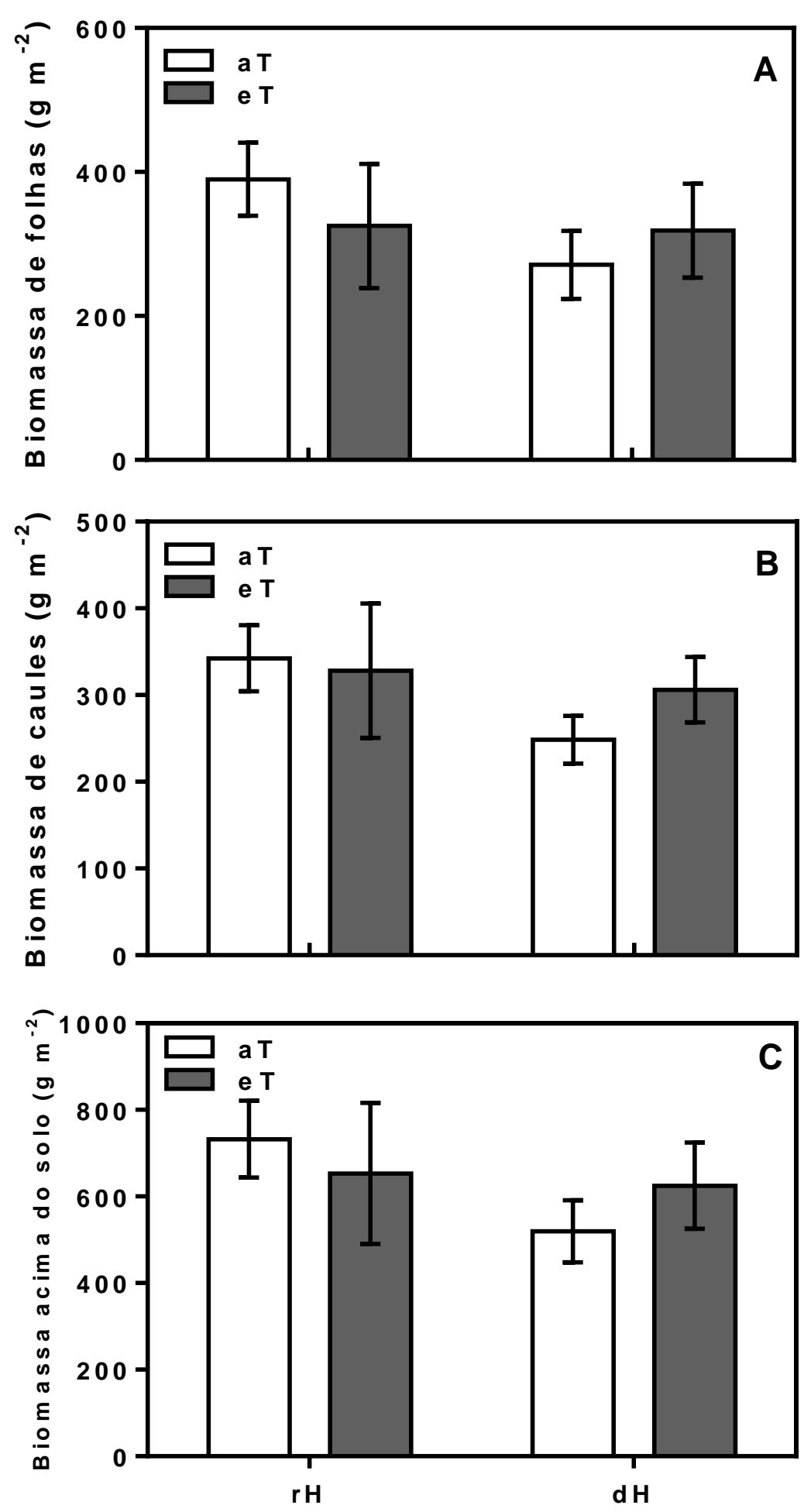

Figura 21: A) Biomassa de folhas, (B) biomassa de caules e (C) biomassa total acima do solo em $\mathrm{g} \mathrm{m}^{-2}$ de $P$. maximum ao final do experimento sob tratamentos combinados de restrição hídrica $(\mathrm{rH})$, disponibilidade hídrica $(\mathrm{dH})$, temperatura ambiente (aT), e temperatura elevada (eT) em sistema T-FACE. 
O fluxo líquido de carbono do ecossistema durante o dia não sofreu alterações pelos tratamentos de restrição hídrica $(\mathrm{p}=0,7799)$, temperatura elevada $(\mathrm{p}=0,9054)$ e tratamento combinado ( $\mathrm{p}=0,8421$ ) (Figura 22A). No período noturno, o NEE também não foi alterado pelos tratamentos de restrição hídrica $(\mathrm{p}=0,6633)$, temperatura $(\mathrm{p}=0,3867)$ e tratamento combinado $(\mathrm{p}=0,1531)$ (Figura 22B).
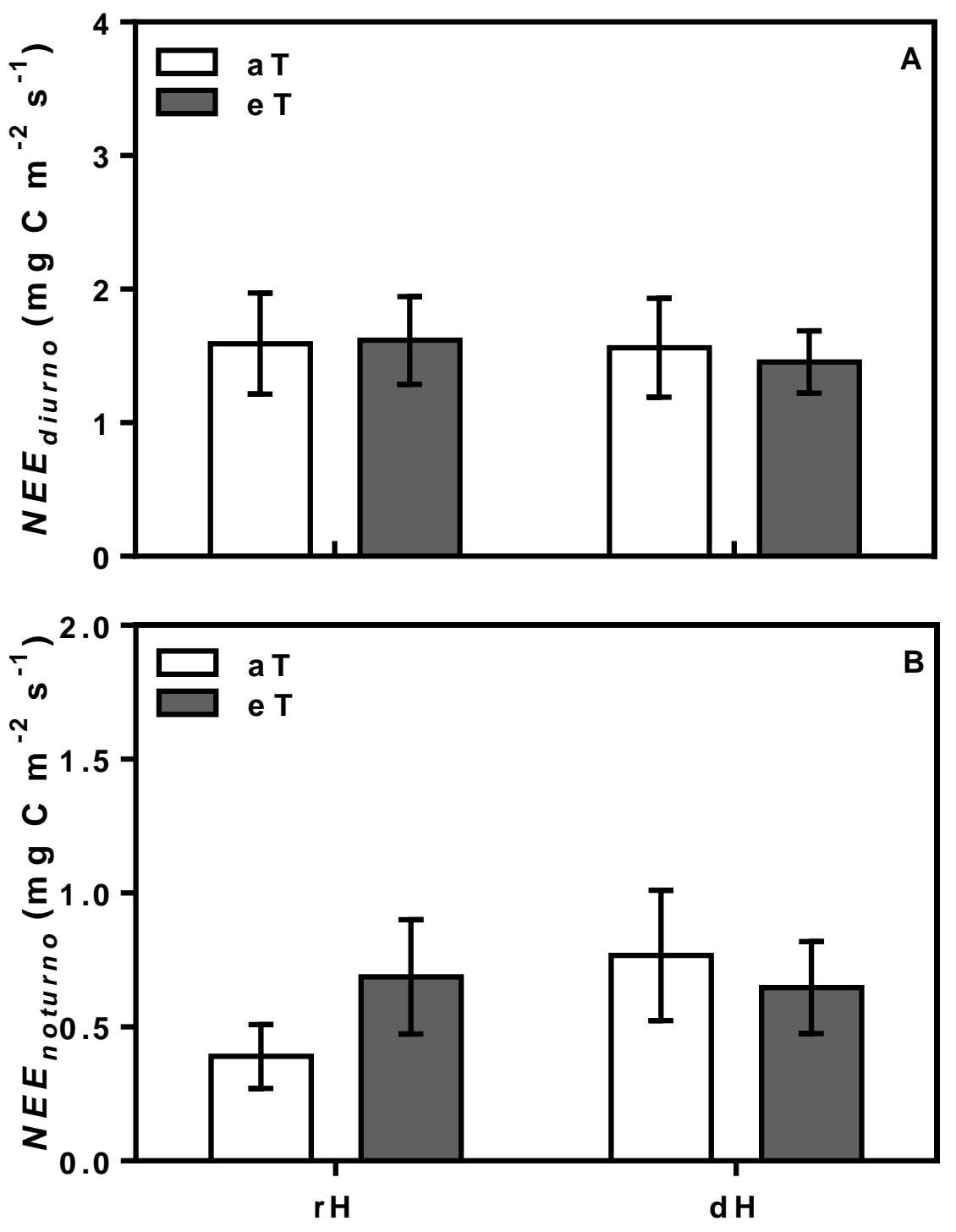

Figura 22: (A) Fluxo líquido de carbono do ecossistema durante período luminoso, medido às 12:00 horas, e (B) período noturno, medido às 21:00 horas, em mg de carbono $\mathrm{m}^{-2} \mathrm{~s}^{-1}$, utilizando câmara de topo aberto em $P$. maximum sob condições de restrição hídrica $(\mathrm{rH})$, disponibilidade hídrica $(\mathrm{dH})$, temperatura ambiente $(\mathrm{aT})$ e temperatura elevada (eT) em sistema T-FACE. Média \pm erro padrão. 
A respiração do solo diurno não sofreu alterações pelos tratamentos de restrição hídrica $(p=0,5655)$, temperatura elevada $(p=0,6804)$ e tratamento combinado $(p=0,2940)$ (Figura 23A). A respiração do solo noturna também não foi alterada nos tratamentos de restrição hídrica $(\mathrm{p}=0,9999)$, temperatura $(\mathrm{p}=0,5390)$ e tratamento combinado $(\mathrm{p}=0,4156)$ (Figura 23B).
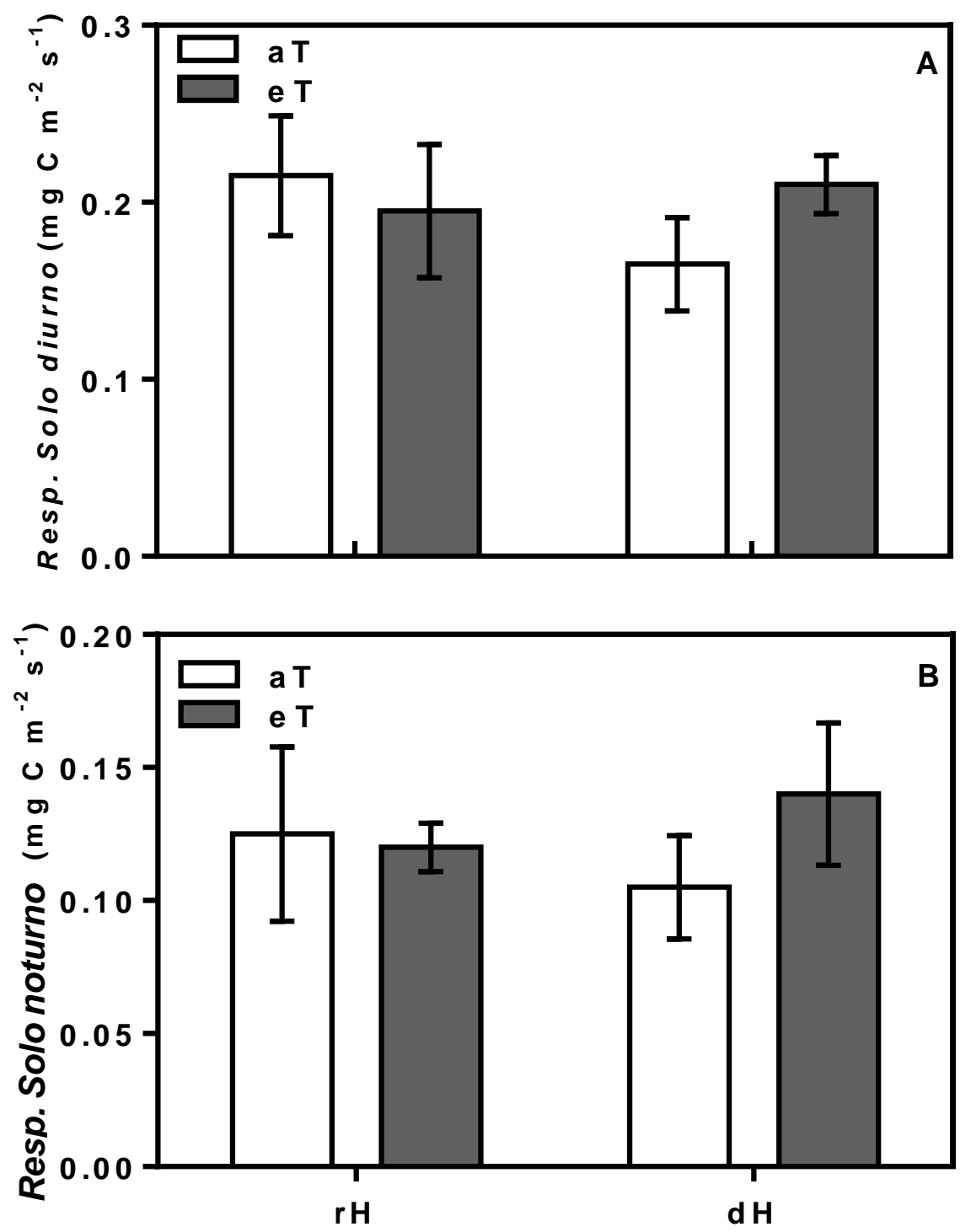

Figura 23: (A) Respiração do solo durante o período luminoso (12:00 horas) e (B) respiração do solo durante o período noturno (21:00 horas) em $\mathrm{mg}$ de carbono $\mathrm{m}^{-2} \mathrm{~s}^{-1}$. Medições realizadas em solo sem plantas, em condições de restrição hídrica $(\mathrm{rH})$, disponibilidade hídrica $(\mathrm{dH})$, temperatura ambiente $(\mathrm{aT})$ e temperatura elevada $(\mathrm{eT}) \mathrm{em}$ sistema T-FACE. Média \pm erro padrão. 
O fluxo de metano não foi alterado pelos tratamentos de restrição hídrica $(\mathrm{p}=0,5725)$, temperatura $(\mathrm{p}=0,1876)$ e tratamento combinado $(\mathrm{p}=0,5699)$, e apresentaram valores negativos, com exceção do grupo dH+eT (Figura 24).

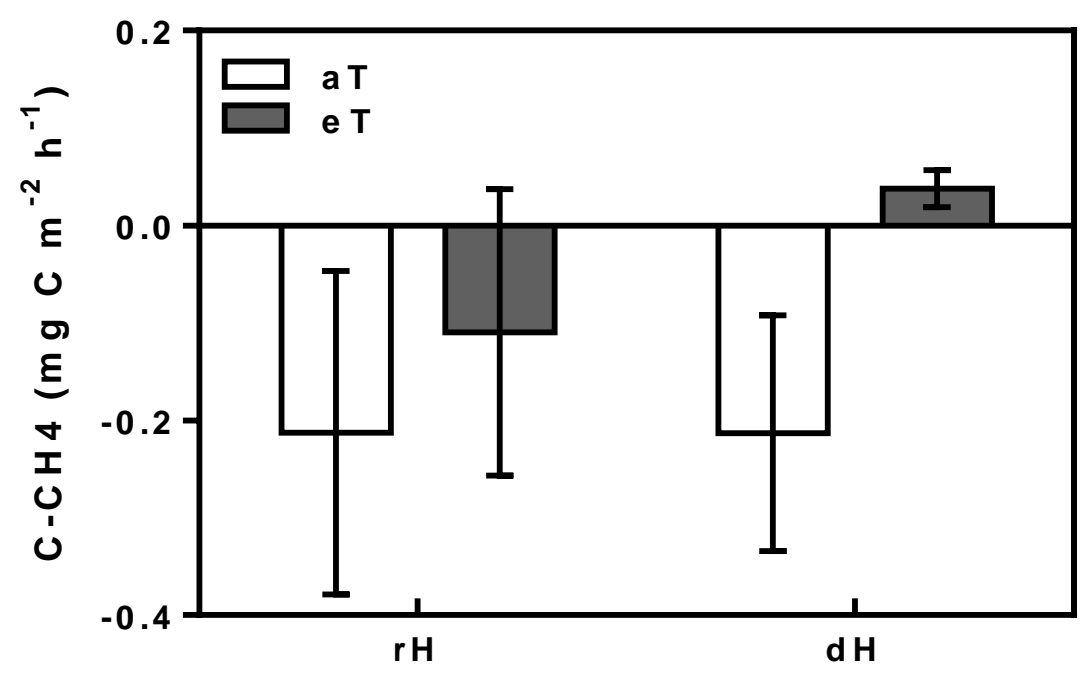

Figura 24: Fluxo de metano $\left(\mathrm{CH}_{4}\right)$ do solo em $\mathrm{mg} \mathrm{C} \mathrm{m}^{-2} \mathrm{~h}^{-1}$ sob cultivo de $P$. maximum em condições de restrição hídrica $(\mathrm{rH})$, disponibilidade hídrica $(\mathrm{dH})$, temperatura ambiente (aT) e temperatura elevada (eT), em sistema $\mathrm{T}$ FACE. Média \pm erro padrão. 


\subsection{Discussão}

O próximo passo na investigação do impacto das mudanças climáticas nas pastagens tropicais foi a elucidação das alterações no ciclo do carbono desses ecossistemas sob reduzida disponibilidade hídrica e elevada temperatura como é esperado no cenário futuro global, devido às alterações nos padrões de chuva e maior quantidade de gases do efeito estufa (IPCC, 2014). Para isso, o delineamento experimental desse trabalho submeteu um ecossistema de pastagem tropical composto por $P$. maximum a restrição hídrica e elevada temperatura em campo aberto.

Experimentos com restrição hídrica a céu aberto são desafiadores por dois motivos principais: susceptibilidade a variações ambientais e controle do conteúdo de água no solo (AINSWORTH; LONG, 2005). Neste trabalho foi alcançado valores médios no conteúdo de água no solo de $0,49 \mathrm{~m}^{3} \mathrm{~m}^{-3}$ nas parcelas com disponibilidade hídrica e $0,38 \mathrm{~m}^{3} \mathrm{~m}^{-3}$ nas parcelas com restrição hídrica. Em um estudo de $P$. maximum jacq. cv. Tobiatã sob stress hídrico em latossolo, Dias Filho et al. utilizaram valores de $0,45 \mathrm{~m}^{3} \mathrm{~m}^{-3}$ de conteúdo de água no solo como controle e de 0,37 a $0,27 \mathrm{~m}^{3} \mathrm{~m}^{-3}$ como tratamentos de stress hídrico (DIAS FILHO; CORSI; CUSATO, 1989). $\mathrm{Ng}$ et al. encontraram respostas fisiológicas ligadas ao stress hídrico em Panicum maximum var. trichoglume quando submetidos a um conteúdo de água no solo de 0,37 $\mathrm{m}^{3} \mathrm{~m}^{-3}$ (NG; WILSON; LUDLOW, 1975).

Dessa forma, as diferenças nos conteúdos de água no solo entre os tratamentos de disponibilidade hídrica $(\mathrm{dH})$ e restrição hídrica $(\mathrm{rH})$ obtidas neste trabalho foram possivelmente indutoras de um nível moderado de stress hídrico. O stress apenas em nível moderado pode ter sido resultado das taxas pluviométricas observadas durante o experimento, uma vez que o mesmo simula um pasto aberto suscetível às variáveis climáticas.

As primeiras respostas das plantas a um ambiente de seca, com altas temperaturas e baixa umidade do solo, se dão a nível fisiológico, com fechamento dos estômatos seguido do declínio na taxa fotossintética, por diminuição na concentração de $\mathrm{CO}_{2}$ no interior da planta disponível para fotossíntese (ANJUM; XIE; WANG, 2011). Apesar das plantas de mecanismo fotossintético $\mathrm{C}_{4}$ possuírem um mecanismo ativo de concentração de $\mathrm{CO}_{2}$ nos cloroplastos, é bem descrito na literatura uma ligação entre stress hídrico, fechamento dos estômatos e redução na fixação de carbono em espécies $\mathrm{C}_{4}$ que, por sua vez, pode levar a uma menor produtividade e acumulo de biomassa (FAY et al., 2003).

No entanto, neste trabalho, $P$. maximum não apresentou diminuições no acumulo de biomassa de folhas, caules e total, após um período de 43 dias sob restrição hídrica. A 
temperatura elevada também não resultou em alterações na biomassa, assim como o efeito combinado dos tratamentos.

$\mathrm{Na}$ literatura é descrito que o déficit hídrico pode causar reduções no número, tamanho e longevidade das folhas. Em seu estudo, Dias Filho relacionou a menor produtividade de $P$. maximum Tobiatã com diminuição na elongação e número de folhas, causadas pelo stress hídrico (DIAS FILHO; CORSI; CUSATO, 1989). Entretanto, esses resultados foram obtidos em experimentos fechados e em vasos. Já em um experimento sob condições naturais, como executado neste trabalho, as plantas estão livres dos limites causados pelos estudos fechados em casas de vegetação e vasos, e podem expressar diferentes estratégias, mais próximas da realidade.

As plantas $\mathrm{C}_{4}$ são predominantemente de regiões árias e quentes, com frequentes secas. Dessa forma, pastagens compostas por gramíneas $\mathrm{C}_{4}$ podem apresentar características adaptativas de sobrevivência a situações de restrição hídrica e temperatura elevada por longos períodos, como a aclimatação fotossintética, que por sua vez afeta processos fisiológicos e consequentemente o crescimento e produtividade como um todo (GHANNOUM, 2009).

Assim como a biomassa, a fixação líquida do carbono no ecossistema, influenciada principalmente pela taxa fotossintética e respiração autotrófica, não foi alterada pelos tratamentos de restrição hídrica e elevada temperatura, tanto nas medições diurnas quanto noturnas. Dessa forma, é possível inferir que o stress hídrico moderado causado pela restrição hídrica não foi suficiente para causar mudanças fisiológicas nas plantas a ponto de alterar suas taxas fotossintéticas de maneira expressiva na fixação de carbono no ecossistema. Ainda assim, é possível que as plantas estejam fotosintetizando menos, porém também respirando menos durante o dia, o que não traria mudanças para o balanço líquido de carbono no ecossistema.

A relação entre respiração autotrófica e stress hídrico não é ainda bem estudada em nível de ecossistema. No entanto, é reportado na literatura que, de modo geral, a respiração autotrófica tende a diminuir em plantas sob stress hídrico, principalmente por feedbacks negativos causados pela menor assimilação de fotossintatos (FLEXAS et al., 2006). Apesar disso, a diminuição da taxa respiratória das plantas sob stress hídrico é menor do que a diminuição da taxa fotossintética, causando um aumento na razão respiração: fotossíntese e na proporção de carbono liberado/assimilado. Por último, a dinâmica entre respiração e fotossíntese sob stress hídrico é particular de cada espécie e cada caso precisa ser estudado especificamente (LARA; ANDREO, 2011). 
Por outro lado, a relação entre restrição hídrica e respiração do solo vem sendo amplamente estudada, por possuírem uma ligação mais direta. O efluxo de carbono em forma de $\mathrm{CO}_{2}$ decorrente da respiração auto e heterotrófica é um indicador de alocação de carbono abaixo do solo e da produtividade do ecossistema (RAICH; NADELHOFFER, 1989). Assim como o NEE e a biomassa, fatores determinantes da produtividade do ecossistema, a respiração do solo diurno e noturno observadas neste trabalho também não foram alteradas pelos tratamentos de restrição hídrica e temperatura.

Nos experimentos dos capítulos I e II, foi observado maior respiração do solo noturno em tratamento combinado de elevada temperatura e $\left[\mathrm{CO}_{2}\right]$, já o efeito combinado de restrição hídrica e temperatura não causou alteração na respiração do solo. É importante lembrar que nos capítulos I e II foi observada maior produtividade e fixação líquida de carbono pelo ecossistema, o que não foi observado neste capítulo, dessa forma, a ligação entre maior alocação de carbono para o solo e maior atividade auto e heterotrófica no solo não ocorreu.

É descrito na literatura uma relação entre a umidade do solo e a respiração heterotrófica, onde a atividade heterotrófica tende a diminuir em solos com baixa umidade. No entanto, existe uma adaptabilidade da biota do solo ao clima e tipo de solo aonde ocorrem (MANZONI; SCHIMEL; PORPORATO, 2011). No experimento realizado nesse trabalho, a ausência de alterações na respiração do solo pode ser explicada tanto por não ter ocorrido mudanças na produtividade e alocação de carbono para o solo, quanto por uma biota adaptada à climas áridos, como ocorre na região em estudo. Dessa forma, a restrição hídrica efetuada não foi severa a ponto de causar algum tipo de mudança nesse âmbito.

Assim como a respiração do solo, a taxa de metano não foi alterada pelos tratamentos de restrição hídrica e elevada temperatura. É amplamente observado na literatura uma relação negativa entre a umidade do solo e a fixação de $\mathrm{CH}_{4}$ (PRICE et al., 2004; SMITH et al., 2000). Essa relação é explicada pelo fato de que o metano é fixado no solo por bactérias metanotróficas, sendo assim, a água no solo dificulta o acesso ao $\mathrm{CH}_{4}$ como substrato para essas bactérias, uma vez que a solubilidade e a difusão do metano é menor na água do que no ar (HARTMANN; BUCHMANN; NIKLAUS, 2011). Neste trabalho, provavelmente a menor quantidade de água presente no solo sob restrição hídrica não causou uma diminuição no acesso de metano para as bactérias metanotróficas.

Para a pecuária tropical extensiva sem irrigação, pastagens compostas por espécies adaptadas a climas áridos, como P. maximum, podem ser uma fonte eficiente de biomassa sem 
maiores perdas de carbono para a atmosfera no cenário futuro de mudanças climáticas, por serem resistentes à períodos prolongados de baixa umidade do solo e elevada temperatura. 


\subsection{Conclusão}

O cenário de restrição hídrica moderada e temperatura elevada em $2{ }^{\circ} \mathrm{C}$ não causou mudanças no ciclo do carbono do ecossistema de pastagem composto por P. maximum. Esse resultado pode estar relacionado com o fato de que a gramínea em estudo é adaptada a climas secos e quentes e, portanto, menos susceptível a estresses moderados de déficit hídrico e temperatura elevada.

A fixação de carbono do ecossistema se manteve inalterada nos tratamentos, mostrando que, mesmo sob restrição hídrica e elevada temperatura, $P$. maximum é capaz de fixar carbono sem elevar a respiração autotrófica. Esse resultado foi condizente com a biomassa acima do solo, que também não sofreu alterações.

A respiração do solo e o metano liberado pelo solo também não foram afetados pela temperatura elevada e restrição hídrica. Provavelmente não houve maior aporte de biomassa para as raízes nem alterações na atividade heterotrófica do solo com baixa umidade e temperatura elevada.

Estes resultados são positivos para a pecuária extensiva com $P$. maximum, pois, em um futuro com maiores variações nos ciclos e chuva e prováveis período com baixa umidade no solo, esse tipo de pastagem é capaz de manter sua produtividade sem emitir quantidades elevadas de $\mathrm{CO}_{2}$ e $\mathrm{CH}_{4}$ para a atmosfera. 


\section{CONSIDERAÇÕES FINAIS}

\subsection{Tabelas Comparativas}

Em suma, são apresentados abaixo os dados abióticos e bióticos obtidos durante os períodos experimentais a fim de favorecer a compreensão entre os objetivos e as conclusões do presente trabalho.

Tabela 1: Dados abióticos coletados durante os períodos experimentais.

\begin{tabular}{|c|c|c|c|c|c|}
\hline Experimento & $\begin{array}{c}\text { Tipo } \\
\text { fotossintético }\end{array}$ & $\begin{array}{c}\text { Temperatura } \\
\left({ }^{\circ} \mathrm{C}\right)\end{array}$ & $\begin{array}{c}\text { Umidade } \\
\text { Relativa }(\%)\end{array}$ & $\begin{array}{c}\text { Precipitação } \\
\left(\mathrm{mm}^{3}\right)\end{array}$ & $\begin{array}{c}\text { Tempo de } \\
\text { experimento }\end{array}$ \\
\hline 1 & $\mathrm{C}_{3}$ & 23,5 & 82,2 & 120 & $\begin{array}{c}66 \text { dias } \\
\text { (Outono) }\end{array}$ \\
\hline 2 & $\mathrm{C}_{4}$ & 24,4 & 86,9 & 223,9 & $\begin{array}{c}29 \text { dias } \\
\text { (Verão) }\end{array}$ \\
\hline 3 & $\mathrm{C}_{4}$ & 25,9 & 84,8 & 304,7 & $\begin{array}{c}43 \text { dias } \\
\text { (Verão) }\end{array}$ \\
\hline
\end{tabular}

Tabela 2: Dados bióticos coletados durante os períodos experimentais.

\begin{tabular}{|c|c|c|c|c|c|c|c|c|c|}
\hline & \multicolumn{3}{|c|}{ BIOMASSA } & \multicolumn{2}{|c|}{ NEE } & \multicolumn{2}{|c|}{$\begin{array}{l}\text { RESPIRAÇÃO } \\
\text { DO SOLO }\end{array}$} & \multirow[t]{2}{*}{ METANO } \\
\hline & & Folha & Caule & Total & Diurno & Noturno & Diurno & Noturno & \\
\hline \multirow{4}{*}{$\begin{array}{c}\text { Experimento } \\
1\end{array}$} & $\mathrm{aCaT}$ & 247,5 & 269,7 & 517,2 & 1,453 & 0,8 & 0,0525 & 0,040 & $-0,008$ \\
\hline & $\mathrm{aCeT}$ & 166,3 & 357,2 & 538,2 & 1,426 & 0,9 & 0,065 & 0,035 & $-0,005$ \\
\hline & $\mathrm{eCaT}$ & 198,8 & 543,8 & 741,4 & 2,926 & 0,736 & 0,06 & 0,037 & $-0,039$ \\
\hline & $\mathrm{eCeT}$ & 176,6 & 200,2 & 376,8 & 2,906 & 1,016 & 0,0775 & 0,066 & $-0,010$ \\
\hline \multirow{4}{*}{$\begin{array}{c}\text { Experimento } \\
2\end{array}$} & $\mathrm{aCaT}$ & 334,8 & 256,8 & 591,6 & 1,56 & 0,59 & 0,1145 & 0,122 & $-0,036$ \\
\hline & $\mathrm{aCeT}$ & 307,4 & 238,8 & 546,3 & 1,066 & 0,42 & 0,11425 & 0,095 & $-0,029$ \\
\hline & $\mathrm{eCaT}$ & 318,6 & 247,4 & 566,1 & 2,24 & 0,81 & 0,12232 & 0,103 & 0,004 \\
\hline & eCeT & 475,6 & 299,2 & 774,8 & 2,616 & 0,72 & 0,13054 & 0,137 & 0,014 \\
\hline \multirow{4}{*}{$\begin{array}{c}\text { Experimento } \\
3\end{array}$} & $\mathrm{dHaT}$ & 389,9 & 342,4 & 732,3 & 1,592 & 0,39 & 0,215 & 0,125 & $-0,212$ \\
\hline & $\mathrm{dHeT}$ & 546,3 & 328,1 & 653,3 & 1,617 & 0,687 & 0,195 & 0,12 & $-0,109$ \\
\hline & $\mathrm{rHaT}$ & 271,1 & 248,5 & 519,6 & 1,562 & 0,767 & 0,165 & 0,105 & $-0,213$ \\
\hline & rHeT & 774,8 & 306,2 & 624,8 & 1,455 & 0,647 & 0,21 & 0,14 & 0,037 \\
\hline
\end{tabular}




\subsection{Conclusão Geral}

Ao final deste trabalho, considera-se que em um cenário futuro de mudanças climáticas, com elevada $\left[\mathrm{CO}_{2}\right]$ e temperatura, um ecossistema de pastagem tropical composto pela leguminosa $\mathrm{C}_{3}, S$. capitata, terá seu ciclo do carbono alterado, devido a mudanças na alocação da biomassa e provável aceleração na fenologia das plantas. Além disso, esse ecossistema terá maior potencial de dreno de $\mathrm{CO}_{2}$ por apresentar maior fixação do mesmo em nível ecossistêmico. No entanto, essa maior fixação de carbono não será convertida em biomassa de folhas, mas sim de caules, o que pode não ser desejável para a produção de forragem.

Já em um ecossistema composto pela gramínea $\mathrm{C}_{4} P$. maximum e sob os mesmos tratamentos de elevada $\left[\mathrm{CO}_{2}\right]$ e temperatura, o ciclo do carbono também foi alterado, porém, de maneira favorável para a pecuária, pois houve maior fixação de $\mathrm{CO}_{2}$ pelo ecossistema e esse aporte de carbono foi alocado para as folhas, aumentando sua biomassa e produtividade de forragem.

Apesar de em ambos os experimentos a respiração do solo ter sido maior durante a noite nos tratamentos, essa maior liberação de $\mathrm{CO}_{2}$ para a atmosfera não foi suficiente para modificar o NEE noturno.

Por último, quando o ecossistema de pastagem com $P$. maximum foi submetido a um cenário futuro de restrição hídrica e elevada temperatura, não houveram alterações em seu ciclo do carbono quanto a biomassa, o NEE e a respiração do solo. Isso pode ser relacionado com a fato de que $P$. maximum é uma espécie de origem africana e adaptada a climas áridos. Além disso, durante o período experimental o aporte de água no solo pela chuva provavelmente possibilitou apenas um stress hídrico moderado. Assim, para a pecuária tropical extensiva no futuro, a utilização de $P$. maximum como forrageira é uma boa opção por sua resistência a níveis moderados de restrição hídrica e elevada temperatura.

Com isso, conclui-se que os dados obtidos no presente trabalho oferecem suporte cientifico tanto para futuros trabalhos acadêmicos quanto para pecuaristas que desejam informações sobre suas pastagens em um provável cenário futuro de mudança climática. De maneira geral, as mudanças climáticas trarão alterações no ciclo do carbono dos ecossistemas de pastagem, que possuem relevante importância na economia, segurança alimentar e no aquecimento global. Por isso, futuros estudos são necessários para melhor elucidar como essas alterações ocorrerão e quais as possíveis medidas a serem tomadas para utilização mais eficiente desses ecossistemas. 


\section{REFERÊENCIAS BIBLIOGRÁFICAS}

AINSWORTH, E. A.; LONG, S. P. What have we learned from 15 years of free-air CO2 enrichment (FACE)? A meta-analytic review of the responses of photosynthesis, canopy properties and plant production to rising CO2. New Phytologist, v. 165, n. 2, p. 351-372, 2005.

AINSWORTH, E. A.; ROGERS, A. The response of photosynthesis and stomatal conductance to rising [CO 2]: Mechanisms and environmental interactions. Plant, Cell and Environment, v. 30, n. 3, p. 258-270, 2007.

AIRES, L. M. I.; PIO, C. A.; PEREIRA, J. S. Carbon dioxide exchange above a Mediterranean C3/C4 grassland during two climatologically contrasting years. Global Change Biology, v. 14, n. 3, p. 539-555, 2008.

AKIYAMA, $\mathrm{H}$. et al. Relationships between ammonia oxidizers and $\mathrm{N} 2 \mathrm{O}$ and $\mathrm{CH} 4$ fluxes in agricultural fields with different soil types. Soil Science and Plant Nutrition, v. 60, n. 4, p. $520-529,2014$.

ANJUM, S.; XIE, X.; WANG, L. Morphological, physiological and biochemical responses of plants to drought stress. African Journal of Agricultural Research, v. 6, n. 9, p. 2026-2032, 2011.

BARKER, T. Climate Change 2007: An Assessment of the Intergovernmental Panel on Climate Change. Change, v. 446, n. November, p. 12-17, 2007.

BHATT, R. K. et al. Growth, yield and photosynthesis of Panicům maximum and Stylosanthes hamata under elevated CO2. Journal of Environmental Biology, v. 31, n. 4, p. 549-552, 2010.

BONDEAU, A. et al. Modelling the role of agriculture for the 20th century global terrestrial carbon balance. Global Change Biology, v. 13, n. 3, p. 679-706, 2007.

CAMPBELL, B. D.; STAFFORD SMITH, D. M. A synthesis of recent global change research on pasture and rangeland production: Reduced uncertainties and their management 
implications. Agriculture, Ecosystems and Environment, v. 82, n. 1-3, p. 39-55, 2000.

CARRILLO, Y. et al. Response of soil organic matter pools to elevated CO2 and warming in a semi-arid grassland. Plant and Soil, v. 347, n. 1, p. 339-350, 2011.

CARVALHO, D. D. et al. Distribution of current photosynthate in two Guinea grass (Panicum maximum Jacq.) cultivars. Journal of Experimental Botany, v. 57, n. 9, p. 2015-2024, 2006.

CHAKRABORTY, S.; NEWTON, A. C. Climate change, plant diseases and food security: An overview. Plant Pathology, v. 60, n. 1, p. 2-14, 2011.

CHAMBERS, J. Q. et al. Respiration from a Tropical Forest Ecosystem: Partitioning of Sources and Low Carbon Use Efficiency RESPIRATION FROM A TROPICAL FOREST ECOSYSTEM : PARTITIONING OF SOURCES AND LOW CARBON USE EFFICIENCY. v. 14, n. 4, p. 72-88, 2014.

CHAPIN, F. S. et al. The changing global carbon cycle: Linking plant-soil carbon dynamics to global consequences. Journal of Ecology, v. 97, n. 5, p. 840-850, 2009.

CHEN, X.; HUTLEY, L. B.; EAMUS, D. Carbon balance of a tropical savanna of northern Australia. Oecologia, v. 137, n. 3, p. 405-416, 2003.

CLARK, D. A. et al. Measuring Net Primary Production in Forests: Concepts and Field Methods. Ecological Applications, v. 11, n. 2, p. 356-370, 2001.

CURTIS, P. S. A meta-analysis of leaf gas exchange and nitrogen in trees grown under elevated carbon dioxide. Plant, Cell and Environment, 1996.

DAVIDSON, E. A.; JANSSENS, I. A. Temperature sensitivity of soil carbon decomposition and feedbacks to climate change. Nature, v. 440, n. 7081, p. 165-173, 2006.

DIAS FILHO, M. B.; CORSI, M.; CUSATO, S. RESPOSTAS MORFOLOGICAS DE PANNICUM MAXIMUM JACQ. cv . TOBIATÃ AO ESTRESSE HÍDRICO. Pesquisa 
Agropecuária Brasileira, v. 24, n. 7, p. 893-898, 1989.

DRAKE, B. G.; GONZALEZ-MELER, M. A.; LONG, S. P. MORE EFFICIENT PLANTS: A Consequence of Rising Atmospheric $\mathrm{CO} 2$ ? Annual review of plant physiology and plant molecular biology, v. 48, p. 609-639, 1997.

DUKES, J. S.; MOONEY, H. A. Does global change increase the success of biological invaders? Trends in Ecology and Evolution, v. 14, n. 4, p. 135-139, 1999.

EHLERINGER, J. R.; CERLING, T. E.; HELLIKER, B. R. C 4 photosynthesis, atmospheric CO 2 , and climate. Oecologia, v. 112, n. 3, p. 285-299, 1997.

EL-SHARKAWY, M. A. Overview: Early history of crop growth and photosynthesis modeling. BioSystems, v. 103, n. 2, p. 205-211, 2011.

EUCLIDES, V. P. B. et al. Avaliação dos capins mombaça e massai sob pastejo. Revista Brasileira de Zootecnia, v. 37, n. 1, p. 18-26, 2008.

FAY, P. A. et al. Productivity responses to altered rainfall patterns in a $\mathrm{C}$ 4-dominated grassland. Oecologia, v. 137, n. 2, p. 245-251, 2003.

FERRAZ, J. B. S.; FELÍCIO, P. E. DE. Production systems - An example from Brazil. Meat Science, v. 84, n. 2, p. 238-243, 2010.

FIELD, C. B. et al. Feedbacks of Terrestrial Ecosystems to Climate Change. Annual Review of Environment and Resources, v. 32, n. 1, p. 1-29, 2007.

FLEXAS, J. et al. Keeping a positive carbon balance under adverse conditions: responses of photosynthesis and respiration to water stress. Physiologia Plantarum, v. 127, n. Kirschbaum 1988, p. 343-352, 2006.

GHANNOUM, O. C4 photosynthesis and water stress. Annals of Botany, v. 103, n. 4, p. 635$644,2009$. 
GOMEZ-CASANOVAS, N. et al. Net ecosystem exchange modifies the relationship between the autotrophic and heterotrophic components of soil respiration with abiotic factors in prairie grasslands. Global Change Biology, v. 18, n. 8, p. 2532-2545, 2012.

GONZALEZ-MELER, M. A.; TANEVA, L.; TRUEMAN, R. J. Plant respiration and elevated atmospheric CO2 concentration: Cellular responses and global significance. Annals of Botany, v. 94, n. 5, p. 647-656, 2004.

GONZALEZ-MELER, M. A. et al. Experimental Air Warming of a Stylosanthes capitata, Vogel Dominated Tropical Pasture Affects Soil Respiration and Nitrogen Dynamics. Frontiers in Plant Science, v. 8, article 46, 2017.

HALL, W. et al. Climate Change in Queensland's Grazing Lands: Ii. An Assessment of the Impact on Animal Production From Native Pastures. The Rangeland Journal, v. 20, n. 2, p. $177,1998$.

HANSEN, A. J. et al. Global Change in Forests: Responses of Species, Communities, and Biomes. BioScience, v. 51, n. 9, p. 765, 2001.

HARTMANN, A. A.; BUCHMANN, N.; NIKLAUS, P. A. A study of soil methane sink regulation in two grasslands exposed to drought and N fertilization. Plant and Soil, v. 342, n. 1-2, p. 265-275, 2011.

HUNT, S. Measurements of photosynthesis and respiration in plants. Physiologia plantarum, v. 117, p. 314-325, 2003.

INMET, Instituto Nacional de Meteorologia. Disponível em http://www.inmet.gov.br/portal/. Acessado em 25/06/2017.

IPCC. Climate Change 2014: Mitigation of Climate Change. [s.l: s.n.].

IRVING, L. Carbon Assimilation, Biomass Partitioning and Productivity in Grasses. 
Agriculture, v. 5, n. 4, p. 1116-1134, 2015.

KER, J. C. LATOSSOLOS DO BRASIL:UMA REVISÃO. Genomos, v. 5, n. 1, p. 17-40, 1997.

KIMBALL, B. A et al. Comparisons of Responses of Vegetation to Elevated Carbon Dioxide in Free-Air and Open Top Chamber Facilities. Advances in Carbon Dioxide Effects Research, n. 61, p. 228, 1997.

LAL, R. Carbon sequestration. Philosophical transactions of the Royal Society of London. Series B, Biological sciences, v. 363, n. 1492, p. 815-830, 2008.

LAMBERS, H.; ATKIN, O. K.; MILLENAAR, F. F. Respiratory Patterns in Roots in Relation to Their Functioning. [s.l: s.n.].

LARA, M. V.; ANDREO, C. S. C4 Plants Adaptation to High Levels of CO2 and to Drought Environments. In: Abiotic Stress in Plants - Mechanisms and Adaptations. [s.1: s.n.]. p. 415428.

LEE, J.-S. Combined effect of elevated $\mathrm{CO} 2$ and temperature on the growth and phenology of two annual C3 and C4 weedy species. Agriculture, Ecosystems \& Environment, v. 140, n. 3, p. 484-491, 2011.

LONG, S. P. et al. Global food insecurity. treatment of major food crops with elevated carbon dioxide or ozone under large-scale fully open-air conditions suggests recent models may have overestimated future yields. Philosophical transactions of the Royal Society of London. Series B, Biological sciences, v. 360, n. 1463, p. 2011-2020, 2005.

LONG, S. P. et al. Food for thought: lower-than-expected crop yield stimulation with rising CO2 concentrations. Science (New York, N.Y.), v. 312, n. 5782, p. 1918-1921, 2006.

LONG, S. P.; DRAKE, B. G. Effect of the Long-Term Elevation of $\mathrm{CO}(2)$ Concentration in the Field on the Quantum Yield of Photosynthesis of the C(3) Sedge, Scirpus olneyi. Plant 
physiology, v. 96, n. 1, p. 221-226, 1991.

MAIA, S. M. F. et al. Changes in soil organic carbon storage under different agricultural management systems in the Southwest Amazon Region of Brazil. Soil and Tillage Research, v. 106, n. 2, p. 177-184, 2010.

MANZONI, S.; SCHIMEL, J. P.; PORPORATO, A. Responses of soil microbial communities to water stress: results from a meta-analysis. Ecology, v. 93, n. 4, p. 930-938, 2011.

MARTINEZ, C. A. et al. Moderate warming increases PSII performance , antioxidant scavenging systems and biomass production in Stylosanthes capitata Vogel. Environmental and Experimental Botany, v. 102, p. 58-67, 2014.

MARUR, C. J.; FARIA, R. T. Photosynthesis of individual leaves in a coffee plant. Acta Science Agronomic, v. 28, n. 3, p. 331-335, 2006.

MARUR, C. J.; FARIA, R. T. DE. A chamber for measurement of net photosynthesis on a whole plant. v. 29, p. 415-419, 2007.

MILLAN-ALMARAZ, J. R. et al. Advantages and disadvantages on photosynthesis measurement techniques: A review. African Journal of Biotechnology, v. 8, n. 25, p. 73407349, 2009.

MORENO, L. S. B. et al. Base temperature determination of tropical Panicum spp. grasses and its effects on degree-day-based models. Agricultural and Forest Meteorology, v. 186, p. 26$33,2014$.

MORGAN, J. A et al. Elevated CO2 enhances water relations and productivity and affects gas exchange in C-3 and C-4 grasses of the Colorado shortgrass steppe. Global Change Biology, v. 7, n. 4, p. 451-466, 2001.

MOSIER, A. R. et al. CH4 and N20 fluxes in the Colorado shortgrass steppe : 1 . Impact of landscape and nitrogen addition oxide flux measurement fluxes contribute of the annual 4 consumption tion to minimum vice similar as well as similar seasonal and loam soils fertilized 
w. Global Biogeochemical Cycles, v. 10, n. 3, p. 387-399, 1996.

NG, T. T.; WILSON, J. R.; LUDLOW, M. M. Influence of Water Stress on Water Relations and Growth of a Tropical $\left(\mathrm{C}_{4}\right)$ Grass, $<\mathrm{I}>$ Panicum maximum $</ \mathrm{I}>$ var. $<\mathrm{I}>$ trichoglume $</ \mathrm{I}>$. Functional Plant Biology, v. 2, n. 4, p. 581-595, 1 dez. 1975.

NIU, S. et al. Ecosystem Carbon Fluxes in Response to Warming and Clipping in a Tallgrass Prairie. Ecosystems, v. 16, n. 6, p. 948-961, 2013.

NORBY, R. J. et al. Tree responses to rising CO2 in field experiments: Implications for the future forest. Plant, Cell and Environment, v. 22, n. 6, p. 683-714, 1999.

PARMESAN, C. et al. A globally coherent fingerprint of climate change impacts across natural systems. Nature, v. 421, n. 6918, p. 37-42, 2003.

PENDALL, E. et al. Elevated CO2 stimulates soil respiration in a FACE wheat field. Basic and Applied Ecology, v. 2, n. 3, p. 193-201, 2001.

PEREIRA, V. V. et al. Características morfogênicas e estruturais de capim-mombaça em três densidades de cultivo adubado com nitrogênio. Revista Brasileira de Zootecnia, v. 40, n. 12, p. 2681-2689, 2011.

POORTER, H. et al. Biomass allocation to leaves, stems and roots: meta-analysis of interspecific variation and environmental control. New Phytologist, v. 193, n. 1, p. 30-50, 2011.

PORTER, J. R. et al. Climate Change 2014: Impacts, Adaptations, and Vulnerability. Food Security and Food Production Systems. p. 485-533, 2014.

PRICE, S. J. et al. Pristine New Zealand forest soil is a strong methane sink. Global Change Biology, v. 10, n. 1, p. 16-26, 2004.

RAICH, J. W.; NADELHOFFER, K. J. Belowground Carbon Allocation in Forest Ecosystems : 
Global Trends. Ecology, v. 70, n. 5, p. 1346-1354, 1989.

RUSTAD, L. E. et al. A meta-analysis of the response of soil respiration, net nitrogen mineralization, and aboveground plant growth to experimental ecosystem warming. Oecologia, v. 126, n. 4, p. 543-562, 2001.

SAGE, R. F.; KUBIEN, D. S. The temperature response of C3 and C4 photosynthesis. Plant, Cell and Environment, v. 30, n. 9, p. 1086-1106, 2007.

SANTOS, M. O. et al. Isolation and characterization of microsatellite loci in tropical forage Stylosanthes capitata Vogel. Molecular Ecology Resources, v. 9, n. 1, p. 192-194, 2009.

SCHLESINGER, W. H.; ANDREWS, J. A. Soil respiration and the global carbon cycle. Biogeochemistry, v. 48, n. 1, p. 7-20, 2000.

SHARKEY, T. D. Understanding carbon partitioning and its role in determining plant growth. Plant, Cell and Environment, v. 38, n. 10, p. 1963-1964, 2015.

SILVA, L. B. C. Efeitos do aquecimento e da elevada concentração atmosférica de CO2 na dinâmica de carbono e nitrogênio do solo e de duas forrageiras tropicais ( Panicum maximum e Stylosanthes capitata ) Efeitos do aquecimento e da elevada concentração atmosférica de CO. [s.l: s.n.].

SMITH, K. A. et al. Oxidation of atmosheric methane in Northen European soils, comparison with other ecosystems, and uncertainties in the global terrestral sink. Global Change Biology, v. 6, p. 791-803, 2000.

SMITH, P. et al. Impact of Global Warming on Soil Organic Carbon. Advances in Agronomy, v. 97, p. $1-43,2008$ a.

SMITH, P. et al. Impact of Global Warming on Soil Organic CarbonAdvances in Agronomy, 2008b. Disponível em: <http://linkinghub.elsevier.com/retrieve/pii/S0065211307000016>. Acesso em: 29 ago. 2017 
TAIZ, L.; ZEIGER, E. Fisiologia Vegetal - Taiz \& Zeiger - 3a edição.pdf, 2006.

TANEVA, L.; GONZALEZ-MELER, M. A. Distinct patterns in the diurnal and seasonal variability in four components of soil respiration in a temperate forest under free-air $\mathrm{CO} 2$ enrichment. Biogeosciences, v. 8, n. 10, p. 3077-3092, 2011.

TOPP, E.; PATTEY, E. Soils as sources and sinks for atmospheric methane. Canadian Journal of Soil Science, v. 77, n. 2, p. 167-177, 1997.

UPRETY, D. C. et al. Carbon dioxide enrichment technologies for crop response studies. v. 65, n. November, p. 859-866, 2006. 